\title{
Hydrologic and Geochemical Monitoring in Long Valley Caldera, Mono County, California, 1985
}

By C.D. Farrar, M.L. Sorey, S.A. Rojstaczer, C.J. Janik, and T.L. Winnett

U.S. GEOLOGICAL SURVEY

and

By M.D. Clark

U.S. FOREST SERVICE

U.S. GEOLOGICAL SURVEY

Water-Resources Investigations Report 87-4090

广
ஸे
స్

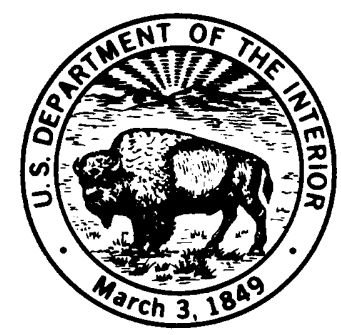

Sacramento, California 


\author{
DEPARTMENT OF THE INTERIOR \\ DONALD PAUL HODEL, Secretary \\ U.S. GEOLOGICAL SURVEY \\ Dallas L. Peck, Director
}

For additional information write to:

District Chief U.S. Geological Survey Federal Building, Room W-2234 2800 Cottage Way

Sacramento, CA 95825
Copies of this report

can be purchased from:

U.S. Geological Survey

Books and Open-File Reports Section Federal Center, B1dg. 810 Box 25425

Denver, CO 80225 
Abstract

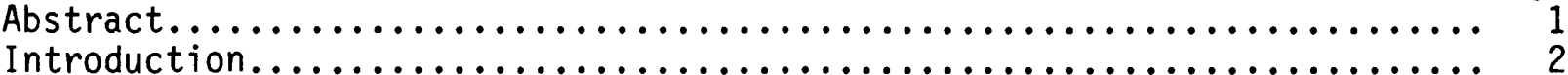

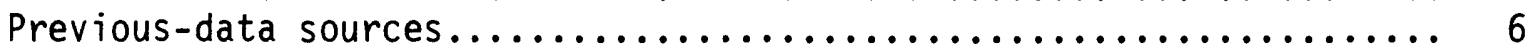

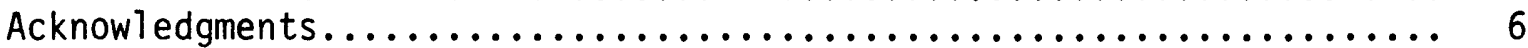

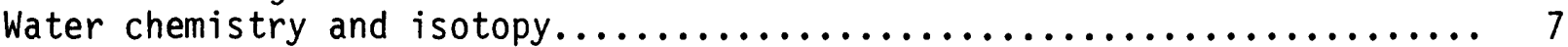

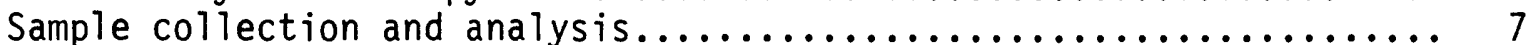

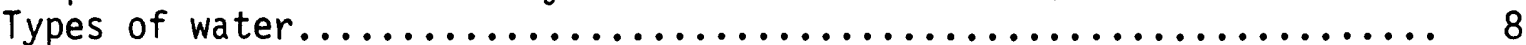

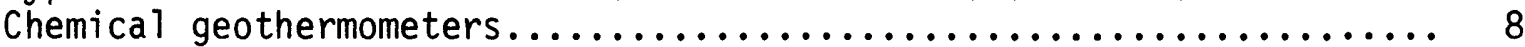

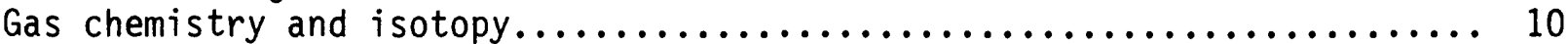

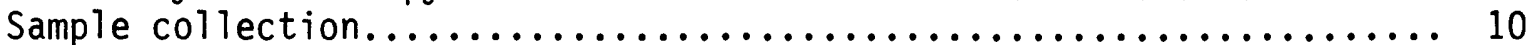

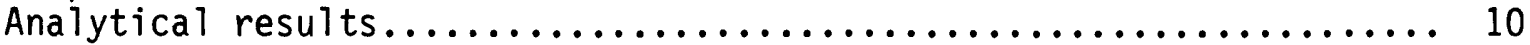

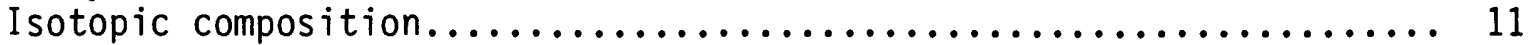

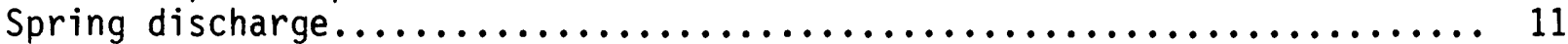

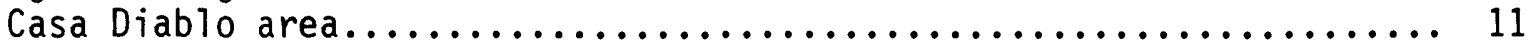

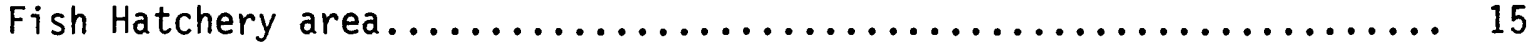

Little Hot Creek springs area........................... 20

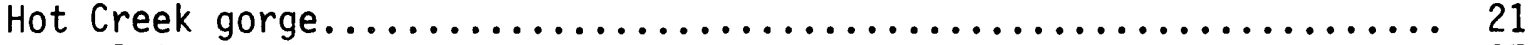

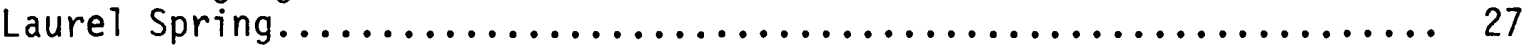

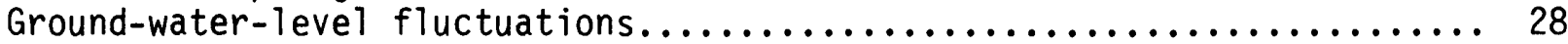

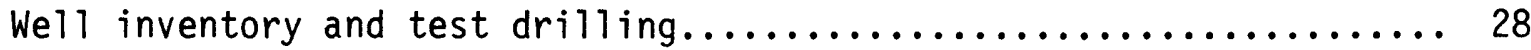

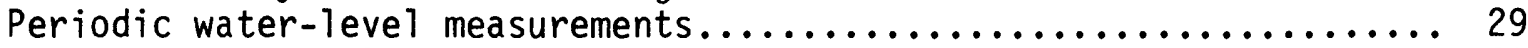

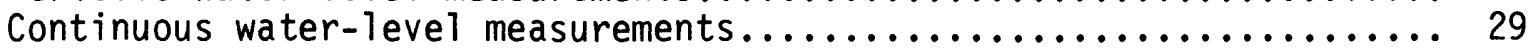

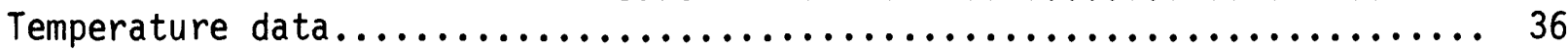

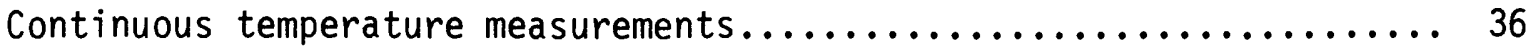

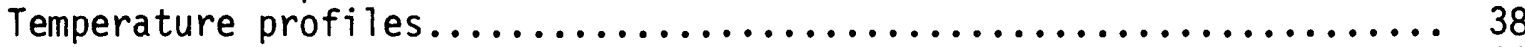

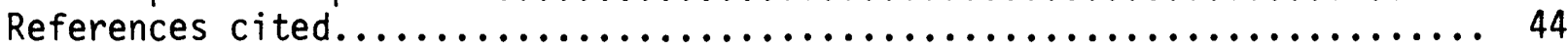

\section{ILLUSTRATIONS}

Figure 1. Map showing location of Long Valley study area............. 3

2. Map of Long Valley study area showing location of wells, springs, surface-water and soil-temperature sites, and

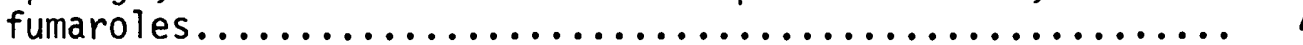

3. Map of Casa Diablo area showing location of thermal springs, fumaroles, wells, and surface-water monitoring sites....... 12

4. Graph showing total thermal-spring discharge and total well discharge at Casa Diablo during 1985................. 14

5. Map of Chance Meadow area showing location of wells and thermal springs in the vicinity of the Fish Hatchery and

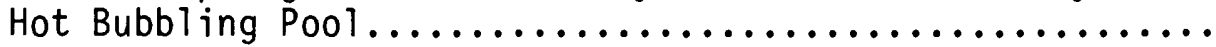
4

6. Graph showing mean daily discharge of thermal-spring group H-II, III at the Fish Hatchery during 1985. 
Figure 7. Graph showing stage record for Hot Bubbling Pool and a tmospheric pressure for well SC-2 during 1985........

8. Hydrographs for Hot Bubbling Pool and the Chance well $(\mathrm{CW}-1)$, and atmospheric pressure measured at well $\mathrm{CH}-10 \mathrm{~B}$ for a 12-day period in March and April 1985.............

9. Map of Little Hot Creek thermal area showing location of

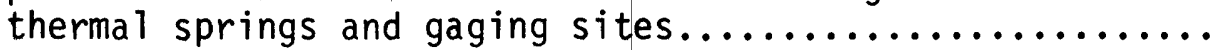

10. Graph showing streamflow and precipitation during 1985 at gaging site below the thermal springs along Little Hot Creek, and flow from thermal spring LHC-1.

11. Map of Hot Creek gorge and vicinity showing location of wells, thermal springs, and surface-water sites........... 22

12. Map of a section of Hot Creek gorge showing location of thermal springs.

raphs showing:

13. Streamflow and chloride flux during 1985 at the Hot Creek flume based on values of river stage and specific conductance....................... 26

14. Discharge during 1985 at the Laurel Spring gaging

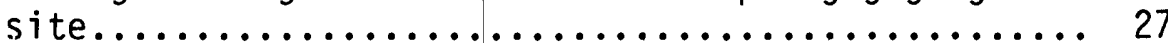

15. Diagram showing well-numbering system.................. 28

16-21. Graphs showing continuous records of depth to water and a tmospheric pressure during 1985 for wells:

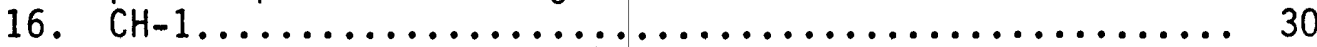

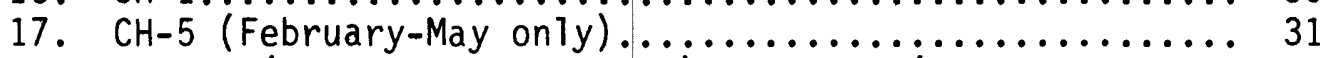

18. $\mathrm{CH}-10 \mathrm{~B}$ (depth to water only) and $\mathrm{SC}-2$ (atmospheric

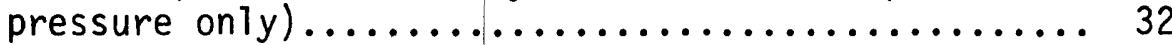

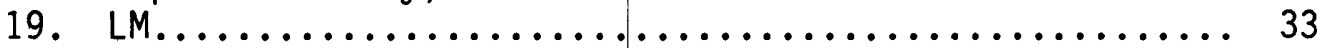

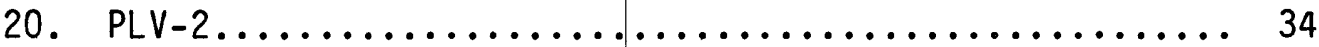

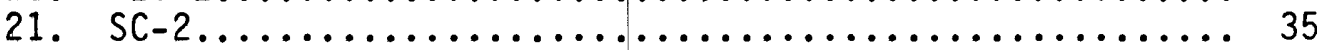

22-23. Graphs showing:

22. Steam-vent temperature at site $B F$ and atmospheric pressure at well SC-2, October-December 1985.......

23. Soil temperature at site LCF on the west side of Long Canyon, January-0ctober $1985 \ldots \ldots \ldots \ldots . \ldots . \ldots 38$

24-31. Diagrams showing temperature profiles and lithology for wells:

24. $\mathrm{CH}-10, \mathrm{CH}-10 \mathrm{~A}$, and $\mathrm{CH}-10 \mathrm{~B} \ldots \ldots \ldots \ldots \ldots \ldots \ldots \ldots$

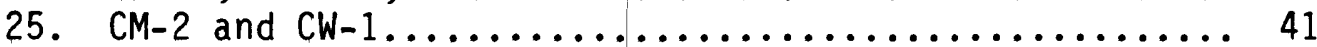

26. $F P-1, M W-1, M W-2, M W-3, M W-4$, and $M W-5 \ldots \ldots \ldots \ldots \ldots . . . . .42$

27. PLV-1, and comparison of most recent temperature profiles for wells $\mathrm{CM}-2, \mathrm{CW}-1, \mathrm{MW}-1, \mathrm{MW}-4$, and

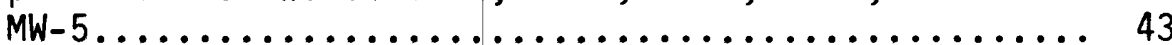

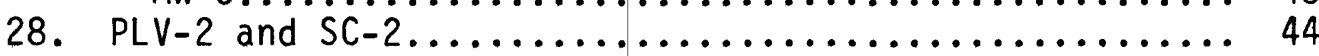


Table 1. Chemical analyses of water from selected springs and wells.... 48

2. Isotopic analyses of water and gas from selected springs,

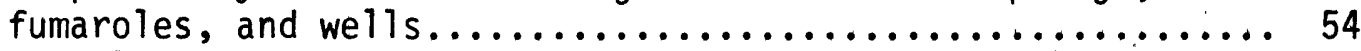

3. Chemical-geothermometer temperatures for selected well and

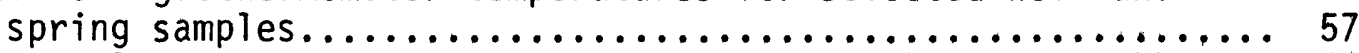

4. Chemical analyses of gas from springs, fumaroles, and welis... 58

5. Ratios of ${ }^{3} \mathrm{He} / 4 \mathrm{He}$ relative to air in helium gas from various thermat features.................................. 59

6. Mean daily discharge for Casa Diabio Hot Springs.............. 60

7. Mean daily discharge for spring group H-II, III at Hot Creek

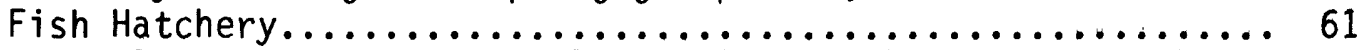

8. Mean daily discharge for Little Hot Creek below the thermal

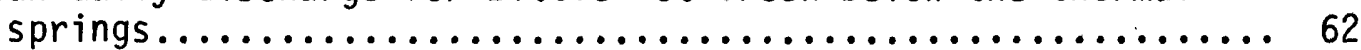

9. Mean daily discharge for Little Hot Creek spring LHC $-1 \ldots \ldots \ldots 63$

10. Daily precipitation at Little Hot Creek, $1985 \ldots \ldots \ldots \ldots \ldots \ldots . \ldots 6$

11. Calculated chloride and boron flux above and below thermal springs in Hot Creek gorge, and calculated thermal-spring discharge in Hot Creek gorge......................... 65

12. Measured and estimated chloride discharge from thermai springs west of Hot Creek gorge, autumn $1985 \ldots \ldots \ldots \ldots \ldots 66$

13. Daily precipitation at Mammoth Ranger Station, 1985.......... 67

14. Mean daily discharge for Laurel Spring, $1985 \ldots . . . \ldots \ldots . \ldots . . .68$

15. Description of wells completed in 1985 in Long Valley area, and wells either not listed in Farrar and others (1985) or listed but for which new altitude data are available.........

16. Water-level measurements in selected wells in Long Valley caldera, $1985 . \ldots \ldots \ldots \ldots \ldots \ldots \ldots \ldots \ldots \ldots \ldots \ldots \ldots \ldots \ldots$ 


\section{CONVERSION FACTORS}

Except as noted below, inch-pound units were used in this report. For those readers who prefer metric (International system) units, the conversion factors are listed below:

Multiply inch-pound unit

acres

feet $(f t)$

feet per year $(\mathrm{ft} / \mathrm{yr})$

cubic feet per second $\left(\mathrm{ft}^{3} / \mathrm{s}\right)$

gallons per minute (gal/min)

inches (in.)

miles (mi).

square miles $\left(\mathrm{mi}^{2}\right)$

cubic miles $\left(\mathrm{mi}^{3}\right)$

pounds (1b)

feet of water
By

\subsection{7}

0.3048

0.3048

28.32

0.0631

25.40

1.609

2.590

4.168

0.4536

29.90

2.989
To obtain metric unit

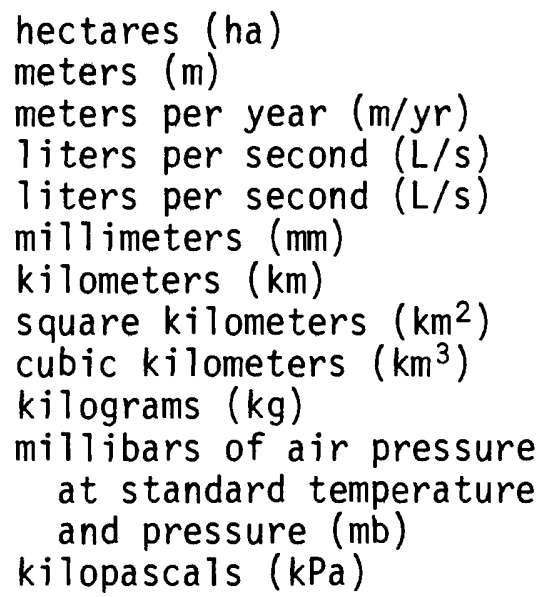

Metric units were used for discharge of streams, springs, and wells. To convert metric units to inch-pound units, multiply the metric unit by the reciprocal of the applicable conversion factor listed above. For example, multiply liters per second by $1 / 0.0631$ or 15.85 to obtain gallons per minute.

Other abbreviations used:

$\begin{array}{cl}{ }^{\circ} \mathrm{C} / \mathrm{km}-\text { degrees Celsius per kilometer } & \mathrm{mg} / \mathrm{L} \text { - milligrams per liter } \\ (\mathrm{Kcal} / \mathrm{s}) / \mathrm{m}^{2}-\mathrm{kilocalories} \text { per second } & \mathrm{mg} / \mathrm{s} \text { - milligrams per second } \\ \text { per square meter } & \mathrm{g} / \mathrm{s} \text { - grams per second } \\ \mathrm{mg} / \mathrm{kg} \text { - milligrams per kilogram } & \text { psig - pounds per square inch--gage }\end{array}$

Temperature is given in degrees Celsius $\left({ }^{\circ} \mathrm{C}\right)$, which can be converted to degrees Fahrenheit $\left({ }^{\circ} \mathrm{F}\right)$ by the following equation:

$$
\text { Temp. }{ }^{\circ} \mathrm{F}=1.8 \text { temp. }{ }^{\circ} \mathrm{C}+32 .
$$

Specific electrical conductance is given in microsiemens per centimeter at $25{ }^{\circ} \mathrm{C}$. Microsiemens per centimeter is numerically equal to micromhos per centimeter.

"Sea level" in this report refers to the National Geodetic Vertical Datum of 1929 (NGVD of 1929)--a geodetic datum derived from a general adjustment of the first order level nets of both the United States and Canada, formerly called Mean Sea Level of 1929.

\section{TRADE NAME DISCLAIMER}

The use of brand, firm, or trade names in this report is for identification purposes only and does not constitute endorsement by the U.S. Geological Survey. 
HYDROLOGIC AND GEOCHEMICAL MONITORING IN LONG VALLEY CALDERA,

MONO COUNTY, CALIFORNIA, 1985

\author{
By C.D. Farrar, M.L. Sorey, S.A. Rojstaczer, C.J. Janik, and T.L. Winnett \\ (U.S. Geological Survey) and \\ M.D. Clark (U.S. Forest Service)
}

\title{
ABSTRACT
}

Hydrologic and geochemical monitoring, by the U.S. Geological Survey, to detect changes caused by magmatic and tectonic processes in the Long Valley caldera has continued through 1985. The monitoring included the collection of the following types of data: chemical and isotopic composition of waters and gases from springs, wells, and steam vents; temperatures in wells, springs, and steam vents; flow rates of springs and streams; water levels in wells; and barometric pressure and precipitation at several sites. In addition, reservoir temperatures for the geothermal system were estimated from computations based on chemical geothermometers applied to fluid samples from wells and springs. Estimates of thermal water discharged from springs were made on the basis of boron and chloride fluxes in surface waters for selected sites in the Casa Diablo area and along the Mammoth-Hot Creek drainage. These data are presented in tables and graphs.

The Long Valley area was relatively quiescent throughout 1985 in terms of geodetic changes and seismic activity. As a consequence, the hydrologic system varied mainly in response to seasonal influences of temperature, atmospheric pressure, and precipitation. However, spring flows near Casa Diablo were influenced by pumping at the geothermal production well field nearby. 


\section{INTRODUCTION}

This report presents hydrologic and geochemical data for the Long Valley caldera, Mono County, California, collected by the U.S. Geological Survey during 1985. The data presented herein were collected as a part of the Geological Survey's program of monitoring the hydrologic system in this area to detect changes caused by magmatic movement and by volcanic and tectonic processes. The study began in 1982, and data collected during 1982-84 are described in Farrar and others (1985) and Sorey and others (1986).

The study area, near the eastern border of central California, encompasses about $400 \mathrm{mi}^{2}$ and includes the Long Valley caldera, an approximately elliptical volcanic depression that measures about 10 miles north to south by 20 miles east to west (fig. 1). The caldera is bounded on the west and south by the steep eastern front of the Sierra Nevada. Volcanic mountains form the northern boundary of the caldera, and a volcanic tableland of lower relief lies to the east. The caldera floor is at an altitude of about 7,000 feet above sea level, but a large area of resurgence in the western and central parts of the caldera rises to over 8,000 feet. Peaks in the adjacent Sierra Nevada exceed 12,000 feet in altitude.

The Long Valley caldera was formed about 0.7 million years ago by the massive extrusion of rhyolitic pyroclastic material and resultant subsidence (Bailey and others, 1976). Subsequent volcanism within and peripheral to the caldera has produced stratovolcanoes, domes, flows, and pyroclastic deposits that vary from rhyolitic to basaltic in composition. The latest episode of volcanism occurred about 500-600 years ago (Miller, 1985) and produced the rhyolitic domes and phreatic explosion pits along the Inyo volcanic chain.

Geological and geophysical surveillance during the past few years has detected periods of increased seismicity and ground deformation centered in the caldera (Miller and others, 1982). These observations combined with the history of episodic volcanism identified in the Quaternary geologic record are indications that future volcanism in this area is a very real possibility.

The Long Valley caldera is within the Mono-Long Valley Known Geothermal Resources Area. One 10-megawatt geothermal power plant is on line at this time (1986) near Casa Diablo, about 3 miles east of Mammoth Lakes (figs. 2 and 3). Exploration for additional geothermal resources is continuing in the central and western parts of the caldera.

Data in this report include: chemical and isotopic analyses of thermal (temperature $>12{ }^{\circ} \mathrm{C}$ ) and nonthermal waters (temperature $\leqq 12{ }^{\circ} \mathrm{C}$ ) from springs and wells; chemical and isotopic composition of gases from springs, wells, and fumaroles; continuous or periodic measurements of flow and stage at selected surface-water sites and springs; continuous temperature records of springs, fumaroles, and soil; temperature profiles in wells; records of total discharge from the production wells at Casa Diablo; continuous and periodic measurements of water levels in wells; well-construction data for wells completed after 1984; and precipitation and barometric-pressure records. The location of data sites is shown in figure 2; detailed location maps are provided for the Casa Diablo, Chance Meadow, Little Hot Creek, and Hot Creek gorge areas. 


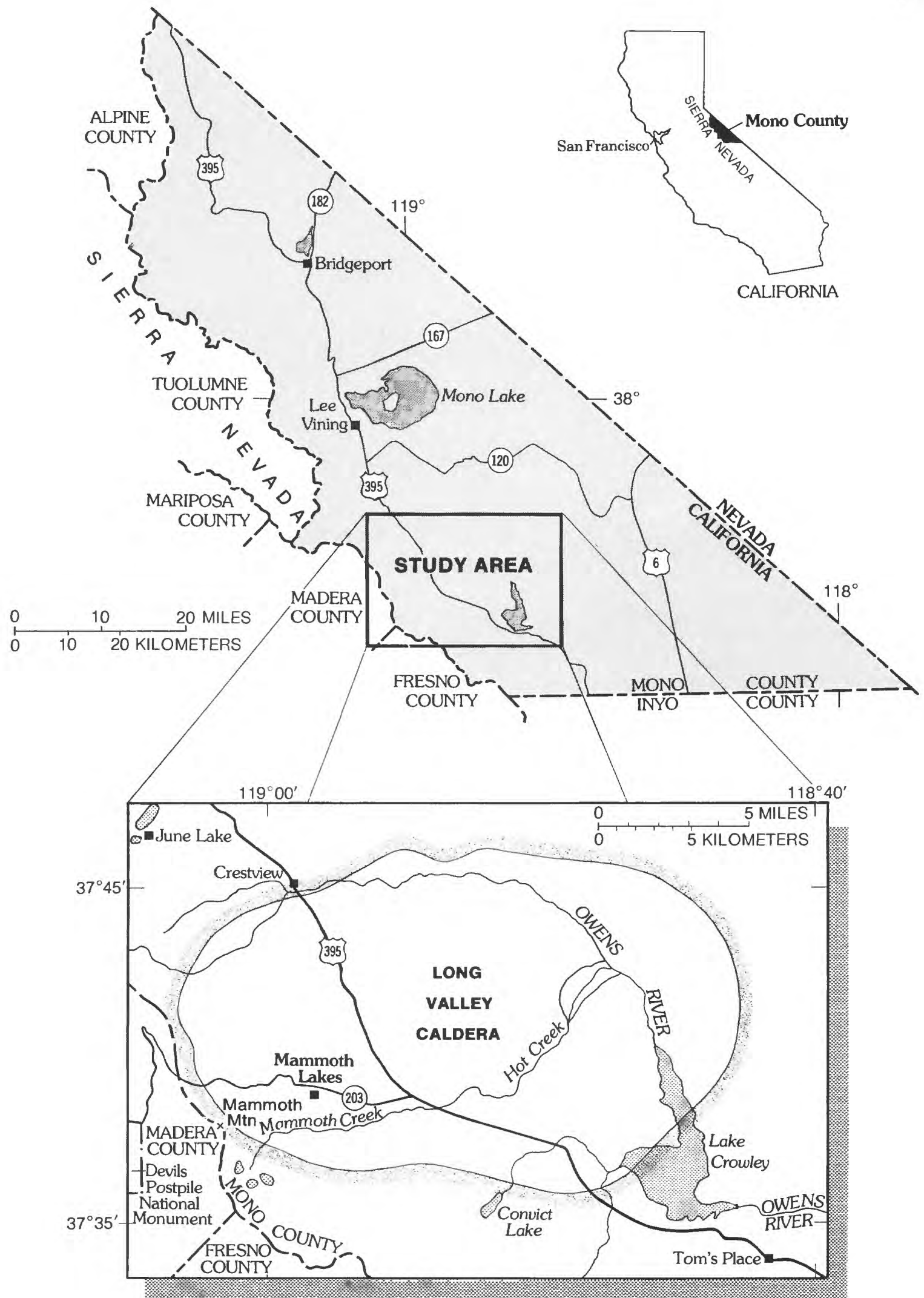

FIGURE 1. - Location of Long Valley study area. 
EXPLANATION

HOLOCENE RHYOLITE DOMES

- Inyo volcanic chain. After Miller, 1985

HOLOCENE PHREATIC CRATERS

- Inyo volcanic chain. After

Miller, 1985

OUTLINE OF CALDERA FLOOR

-After Bailey and Koeppen, 1977

WELL AND DESIGNATION

- DC Nonrecording site

¿ ${ }^{\text {LM Recording site }}$

CH-1 Telemetry site

\section{SPRING AND DESIGNATION}

CS Thermal spring (nonrecording)

HBP Thermal spring (recording site)

BS Nonthermal spring (nonrecording)

LS Nonthermal spring (recording site)

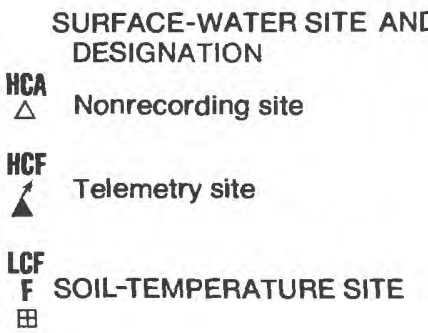

F FUMAROLE

\section{7}

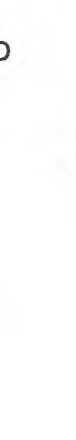

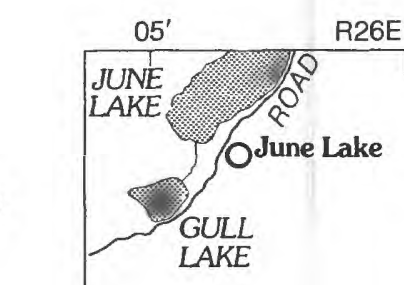

R26E R27E $119^{\circ} 00^{\prime}$
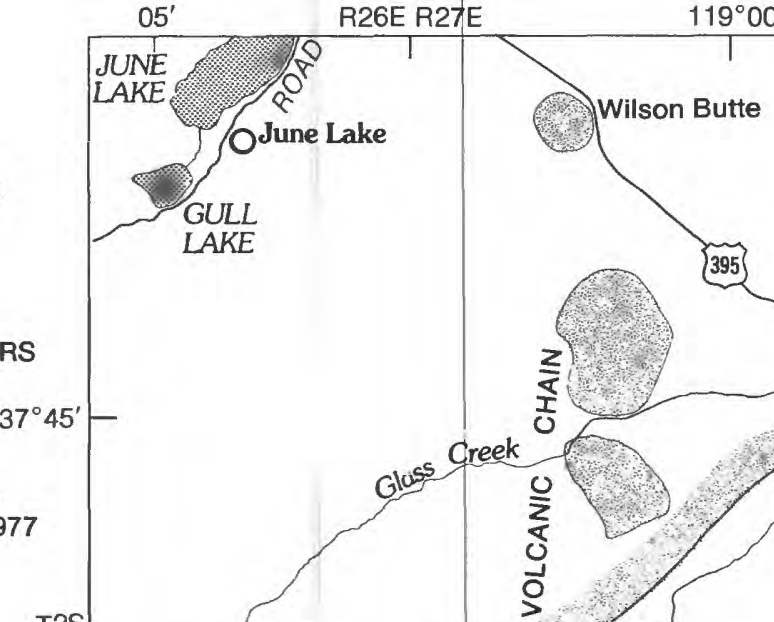

(1)
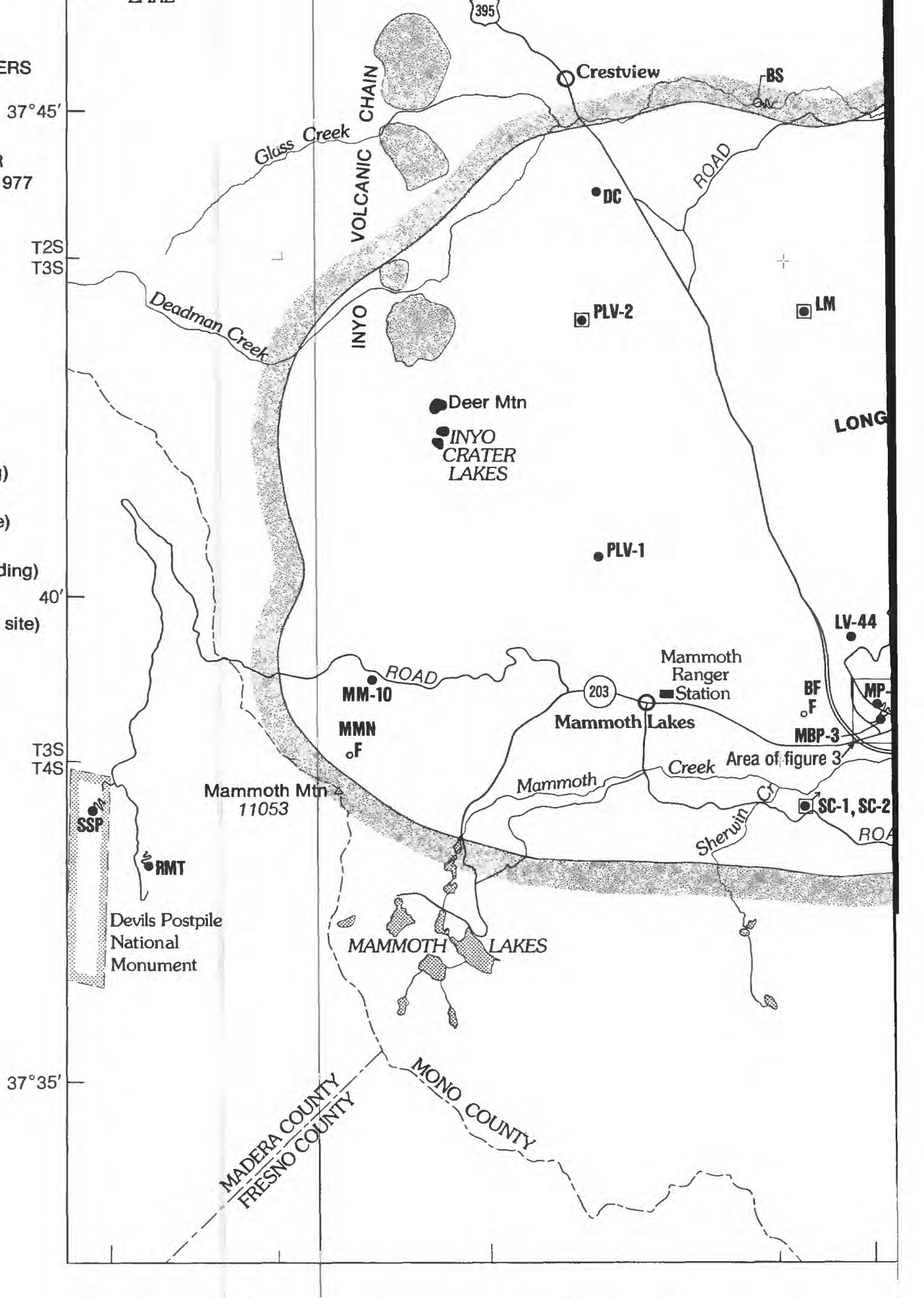

FIGURE 2. - Long Valley study area showing location of wells, springs, surface-water and soil-temperature sites, and fumaroles. 
Bald Mountain

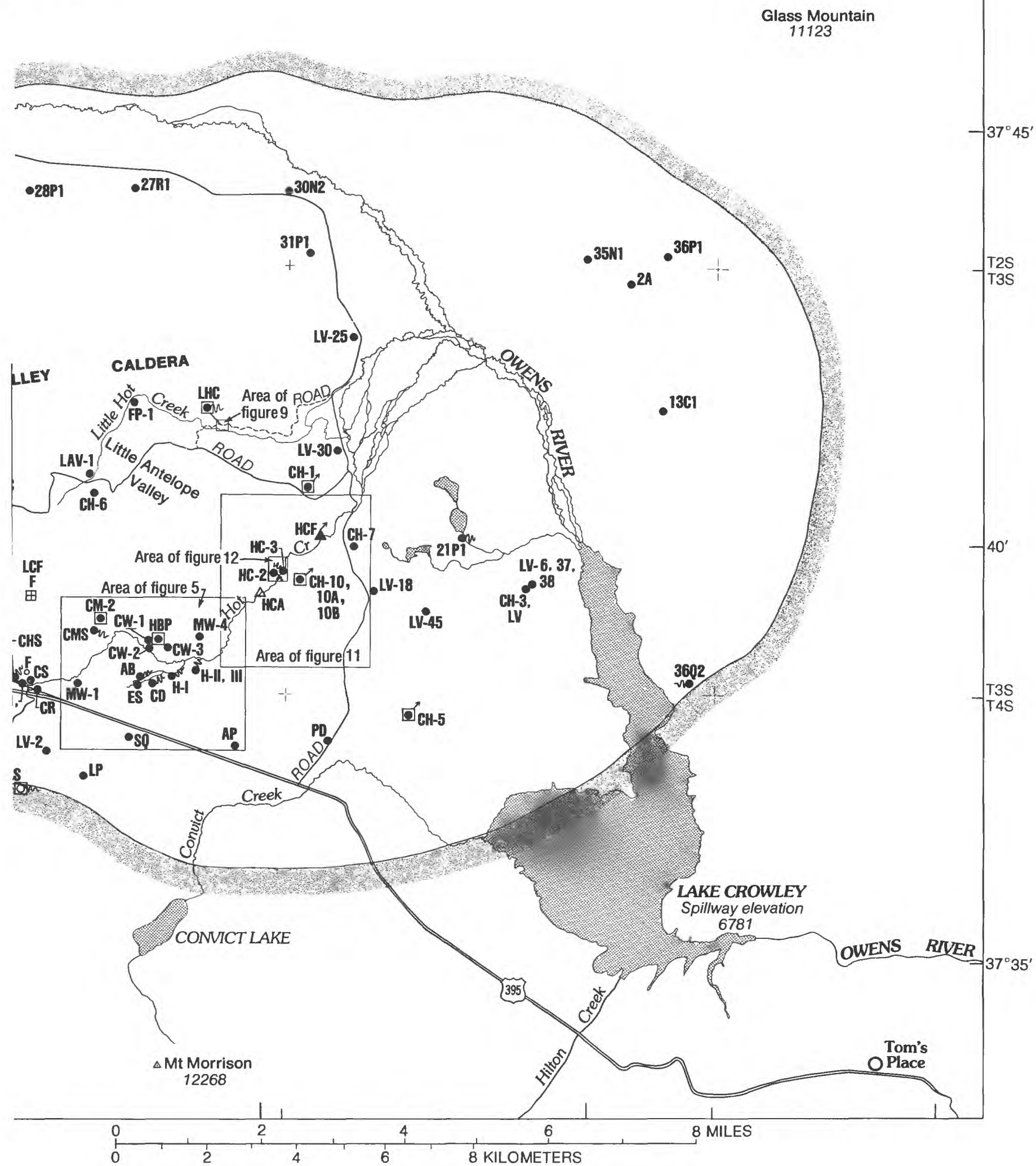


Subsurface-temperature estimates calculated on the basis of chemical geothermometers are provided for selected springs and wells. Calculations of continuous and periodic chloride flux are given for selected sites on the basis of chemical and flow data. The flux measurements are then related to equivalents of thermal-spring flow.

\section{Previous-Data Sources}

The earliest reports of hydrologic conditions in the study area predate 1900. It was not until the 1960 's, however, that the first reports were published that contained extensive collections of hydrologic data. Selected references that contain major hydrologic-lor geochemical-data contributions are given below. (See "References Cited" section for complete citations.)

Bezore and Sherburne, 1985

California Department of Water Resources, 1967

California Department of Water Resources, 1973

Farrar and others, 1985

Fournier and others, 1979
Lewis, 1974

Sorey and Clark, 1981

Sorey and others, 1978

Sorey and others, 1984

U.S. Forest Service, $1980-84$

Willey and others, 1974

\section{Acknowledgments}

Many university and government scientists are collecting hydrologic and geochemical data and conducting experiments in the Long Valley caldera. The cooperation between various individuals and groups has allowed for the exchange of data and ideas and has benefited the endeavor of understanding the hydrologic system. This report mainly summarizes the data collected as a part of the U.S. Geological Survey's program to monitor the hydrologic system to detect changes related to volcanic or tectonic processes. Selected data collected by scientists from other institutions are also included. Fraser Goff, Los Alamos National Laboratory, and Art White, Lawrence Berkeley Laboratory, provided chemical data for water samples from selected sites and for interlaboratory comparison of analytical results. Helium gas isotopic-ratio data from selected springs and steam vents were provided by Mack Kennedy, University of California, Berkeley; Bill Rison, New Mexico Institute of Mining and Technology; and Bob Poreda and Dave Hilton, Scripps Institute of Oceanography. 
The hydrologic-monitoring activities also were facilitated by the cooperation of private citizens, local governmental personnel, and resource developers. Many individuals willingly provided access to and information about their private water wells. Gary Sisson, of the Mammoth County Water District, provided information and reports concerning water-supply wells and exploration activities. Bill Asper, Mammoth Pacific Geothermal Power Plant manager, provided detailed reports of geothermal-fluid production and injection rates for the plant at Casa Diablo and allowed access to production wells and thermal springs for chemical sampling. Keith Higginson and Sheryl Chapman, consultants for the Mammoth/Chance Geothermal Project, provided information and access to production and monitor wells located on the geothermal lease near the Fish Hatchery.

\section{WATER CHEMISTRY AND ISOTOPY}

\section{Sample Collection and Analysis}

Chemical and isotopic analyses of water samples from selected springs and wells are given in tables 1 and 2. Location of sample sites is given in figure 2 and in maps of individual thermal areas. Samples were collected and prepared in the field in accordance with standard U.S. Geological Survey practices (Brown and others, 1970; Thompson, 1975; Wood, 1976; Lico and others, 1982; and Claassen, 1982). The geothermal production wells (MBP-1, $-3,-4,-5$ at Casa Diablo and $\mathrm{CW}-2$ near Hot Bubbling Pool) pose special problems for sampling because well-head temperatures exceed boiling-point temperatures for the local altitude. To avoid steam loss, two sampling techniques were employed: collection with a mini-cyclone separator, and collection of total flow condensed through stainless-steel tubing immersed in an ice-and-water bath. Details of the collection conditions for each well sample are given in footnotes to tables 1 and 2.

Temperatures, and in most cases the $\mathrm{pH}$ and alkalinity, of water samples were measured in the field. Laboratory determinations of $\mathrm{pH}$ and alkalinity are denoted by an "L" in table 1. Laboratory analytical methods for samples analyzed in U.S. Geological Survey laboratories are described in Skougstad and others (1979). The methods used in other laboratories are not documented here. Comparisons of the range in values for various constituents reported by different laboratories analyzing splits of the same sample can be made for the July samples collected from well MBP-1, North spring, and well MBP-3 at Casa Diablo, and the Reds Meadow Tub spring. 
Ground-water samples collected from springs and wells were analyzed for 16 chemical constituents and for stable-isotope ratios of carbon, hydrogen, and oxygen. Surface-water samples were analyzed only to determine fluxes of elements such as $\mathrm{Cl}$ (chlorine) and $\mathrm{B}$ (boron) that can be related to thermal-spring-discharge contributions to Mammoth Creek and Hot Creek. Ground waters in the study area can be classified in a general way into thermal and nonthermal categories. Thermal waters include water with temperatures greater than the mean annual air temperature of about $12{ }^{\circ} \mathrm{C}$. By this definition, thermal waters include deeply circulating ground water that reaches chemical, isotopic, and thermal equilibrium with reservoir rocks. Mixed waters contain variable fractions of undiluted thermal waters and nonthermal meteoric waters. Nonthermal waters include meteoric water that has not attained temperatures significantly above $12{ }^{\circ} \mathrm{C}$.

Samples collected from the geothermal production wells at Casa Diablo may be representative of undiluted thermal water. Such water is characterized by a dissolved-solids concentration greater than $1,200 \mathrm{mg} / \mathrm{L}$ and relatively high concentrations of sodium, potassium, chloride, fluoride, silica, arsenic, boron, and lithium. The thermal waters are sodium chloride type (that is, 50 percent or more of cations are sodium and 50 percent or more of anions are chloride), with distinctly low concentrations of calcium and magnesium. Isotopicaliy, the thermal waters are heavier in oxygen and carbon isotopes than are the nonthermal waters. The ratios of stable isotopes given in table 2 are referenced to SMOW (standard mean ocean water) for oxygen and hydrogen and to the Pee Dee belemnite for carbon (Faure, 1977).

The nonthermal waters are characterized by the samples for Laurel and Big Springs. Dissolved-solids concentrations are less than $200 \mathrm{mg} / \mathrm{L}$. The water type is calcium bicarbonate. Cation composition is more equally distributed between calcium, magnesium, sodium, and potassium than in thermal waters. The concentrations of sodium, potassium, chloride, fluoride, silica, arsenic, boron, and lithium are all significantly lawer than in the thermal waters.

\section{Chemical Geothermometers}

Estimates of subsurface-reservoir temperatures can be obtained from chemical geothermometers that are based on concentrations of silica and ratios of sodium, potassium, calcium, magnesium, and lithium concentrations in water samples (Fournier and Truesde11, 1973; Fournier and Rowe, 1966; Y. K. Kharaka and R. H. Mariner, U.S. Geological Survey, written comm., 1986). Results of previous geothermometer calculations for spring waters are given by Sorey and others (1978), Fournier and others (1979), Mariner and Willey (1976), and Sorey and Lewis (1976). The collection of single-phase samples from wells at Casa Diablo in 1985 simplifies the application of these geothermometers and makes possible improved estimates of reservoir temperatures. 
Results of geothermometer calculations for springs and wells are given in table 3. Four different chemical geothermometers were used: silica-quartz (conductive), $\mathrm{Na} / \mathrm{K}$ (sodium/potassium), $\mathrm{Na}-\mathrm{K}-\mathrm{Ca}$ (sodium-potassium-calcium), and $\mathrm{Mg} / \mathrm{Li}$ (magnesium/lithium). Temperatures were calculated using the computer program "SOLMNEQ," version 6/85 (Kharaka and Barnes, 1973). Equations for these geothermometers are:

Geothermometer

Equation

Silica-quartz

(conductive)

$$
\mathrm{t}\left({ }^{\circ} \mathrm{C}\right)=\frac{1309}{5.19-\log \mathrm{SiO}_{2}}-273
$$

$\mathrm{Na} / \mathrm{K}$

$t\left({ }^{\circ} \mathrm{C}\right)=\frac{1217}{\log (\mathrm{Na} / \mathrm{K})+1.483}-273$

$1 / 3 \mathrm{Na}-\mathrm{K}-\mathrm{Ca}$

$t\left({ }^{\circ} \mathrm{C}\right)=$

$\log (\mathrm{Na} / \mathrm{K})+1 / 3\left[\log \left((\mathrm{Ca})^{1 / 2} / \mathrm{Na}\right)+2.06\right]+2.47$

$\mathrm{Mg} / \mathrm{Li}$

$t\left({ }^{\circ} \mathrm{C}\right)=\frac{2200}{\log \left([\mathrm{Mg}]^{1 / 2} /[\mathrm{Li}]\right)+5.47}-273$

where concentrations of elements are expressed in milligrams per kilogram, and $t\left({ }^{\circ} \mathrm{C}\right)$ is calculated temperature in degrees Celsius.

Good agreement between the various geothermometers is obtained for most sample sites. For wells in the Casa Diablo area, reservoir-temperature estimates based on samples collected in 1985 using the four geothermometers range from about $193{ }^{\circ} \mathrm{C}$ to $228{ }^{\circ} \mathrm{C}$. Previously published results for well END-5, based on a sample collected in 1972, are included for comparison with the 1985 samples collected from the MBP wells. The 1985 samples (single-phase liquid) yield reservoir-temperature estimates that are generally 10-20 degrees lower than the estimates based on the 1972 END-5 sample (two-phase fluid condensed in water bath). The average value of reservoir temperature based on geothermometer results for 1985 samples from all wells in the Casa Diablo area analyzed at the U.S. Geological Survey laboratory in Colorado is $208{ }^{\circ} \mathrm{C}$.

Sites east of the Casa Diablo area give considerably lower reservoir-temperature estimates, mostly from about $140{ }^{\circ} \mathrm{C}$ to $190{ }^{\circ} \mathrm{C}$. Lower temperature estimates in these areas cannot be explained by simple dilution of thermal waters by meteoric waters along the ground-water flow path because the geothermometers based on ionic ratios are relatively insensitive to this factor. Either these waters were heated in a cooler part of the reservoir or they have undergone chemical reequilibration along the flow path before discharging at the surface. 


\section{GAS CHEMISTRY AND ISOTOPY \\ Sample Collection}

Hydrothermal fluids in the Long Valley area discharge as liquid, gas, or combinations of the two. Many of the thermal springs show evidence of significant gas discharge as entrained bubbles in the water. Geothermal wells discharge single- and two-phase fluids, which can be split into gas and liquid by using a separator fitted to the discharge line.

Gas samples were collected from nine different sites during 1985 (table 4). The procedure for sample collection varied according to the source of the sample. For springs and fumaroles, a funnel or tube was inserted into or over the vent, and the gas was conducted through viny? tubing to evacuated glass cylinders containing sodium hydroxide solution. The main concern in field procedures is to insure exclusion of atmospheric gas from the sample. For the wells sampled, a mini-cyclone separator was used. The separator was attached to a valve on the side of the pump discharge line and samples were collected in evacuated glass cylinders.

\section{Analytical Results}

The chemical analyses given in table 4 show that noncondensable gases associated with the hydrothermal system consist predominantly of $\mathrm{CO}_{2}$ (generally greater than 95 percent), with lesser amounts of $\mathrm{H}_{2} \mathrm{~S}, \mathrm{H}_{2}, \mathrm{CH}_{4}$, $\mathrm{NH}_{3}$, He, $\mathrm{N}_{2}, \mathrm{O}_{2}$, and $\mathrm{Ar}$. The ratio of steam to noncondensable gases calculated for five samples shows that the vapor phase is predominantly water (as steam); other gases make up only a fraction of a percent. The highest concentrations of hydrogen sulfide and hydrogen are found in the gases from the five sites in the Casa Diablo area, followed by the sites in the Fish Hatchery area; concentrations are distinctly lower at both the Hot Creek gorge and Little Hot Creek areas. Ammonia closely follows the same distribution pattern. Oxygen and nitrogen generally are inversely related to $\mathrm{H}_{2}, \mathrm{H}_{2} \mathrm{~S}$, and $\mathrm{NH}_{3}$ concentrations. Helium is present in greatest concentrations at the Casa Diablo sites and Little Hot Creek Spring and in much lower concentrations at the Fish Hatchery and Hot Creek gorge sites.

Because only two sites (MBP-1 and MBP-3) were sampled more than once during the 1985 period, little can be said about temporal variations in gas chemistry. No significant chemical differences are apparent between the May and July samples from sites MBP-1 and MBP-3 (table 4). An indication of the variability in gas composition from any one area can be appreciated by comparing the results of analyses from the two spring vents (both labeled HC-4) located about 15 feet apart in Hot Creek gorge. A large difference is seen in the $\mathrm{CO}_{2}$ and $\mathrm{N}_{2}$ percentages, and significant differences are seen for $\mathrm{CH}_{4}$ and $\mathrm{Ar}$ as well. These differences indicate the need for caution when comparing results collected by different investigators unless confirmation is obtained that the same vent was sampled in each case. 
Samples were collected in 1985 for oxygen-, hydrogen-, and carbon-isotope determinations in liquid and gas phases at the same sites from which water samples were collected for chemical analysis. Variability in results presented in table 2 could be due to a combination of factors: actual isotopic variations, differences in laboratory procedures in different laboratories, differences in sampling points, physical character of the springs when sampled, and random errors. Results show the gas phase to be generally lighter in the respective isotopes than the liquid phase at each site. Exceptions to this observation are seen for the carbon analyses from well MBP-3. The concentration of lighter isotopes in the vapor phase is consistent with theoretical considerations of the fractionation process.

Monitoring of additional geochemical constituents by other investigators continued during 1985 and included hydrogen-gas concentrations in fumaroles and soil gas; mercury and radon in soil gas; radon in the H-II, III springs at the Fish Hatchery; and helium in ground water produced from the AP well at the Mammoth-June Lake airport. Ratios of ${ }^{3} \mathrm{HE} /{ }^{4} \mathrm{He}$ in helium gas from thermal springs, fumaroles, and wells to the helium ratio in air were determined for samples collected during 1985 by B.M. Kennedy (University of California, Berkeley) and R. Poreda and D. Hilton (Scripps Institute of Oceanography). These data are given in table 5, along with data from samples collected in previous years. Thermal features are arranged in table 5 by location from west to east across the caldera.

\section{SPRING DISCHARGE}

\section{Casa Diablo Area}

Casa Diablo Hot Springs (sec. 32, T. 3 S., R. 28 E.,) is near the intersection of U.S. Highway 395 and State Highway 203 (fig. 3). A summary of the available historical record for this area was given by Farrar and others (1985). Thermal fluid currently discharges at Casa Diablo in two areas, a lower area adjacent to old Highway 395 and an upper area 0.5 mile to the northeast. Discharge at the upper area occurs in fumaroles and steamheated springs and seeps. Most prominent among these features is the Lower Clay Pit Fumarole (labeled CDF in fig. 3), which continued to discharge steam and noncondensable gases at boiling-point temperatures during 1985. Monitoring of emissions of hydrogen gas from the nearby $\mathrm{H}$-Probe fumarole was continued during 1985 (K. A. McGee, U.S. Geological Survey, oral commun., 1986). 


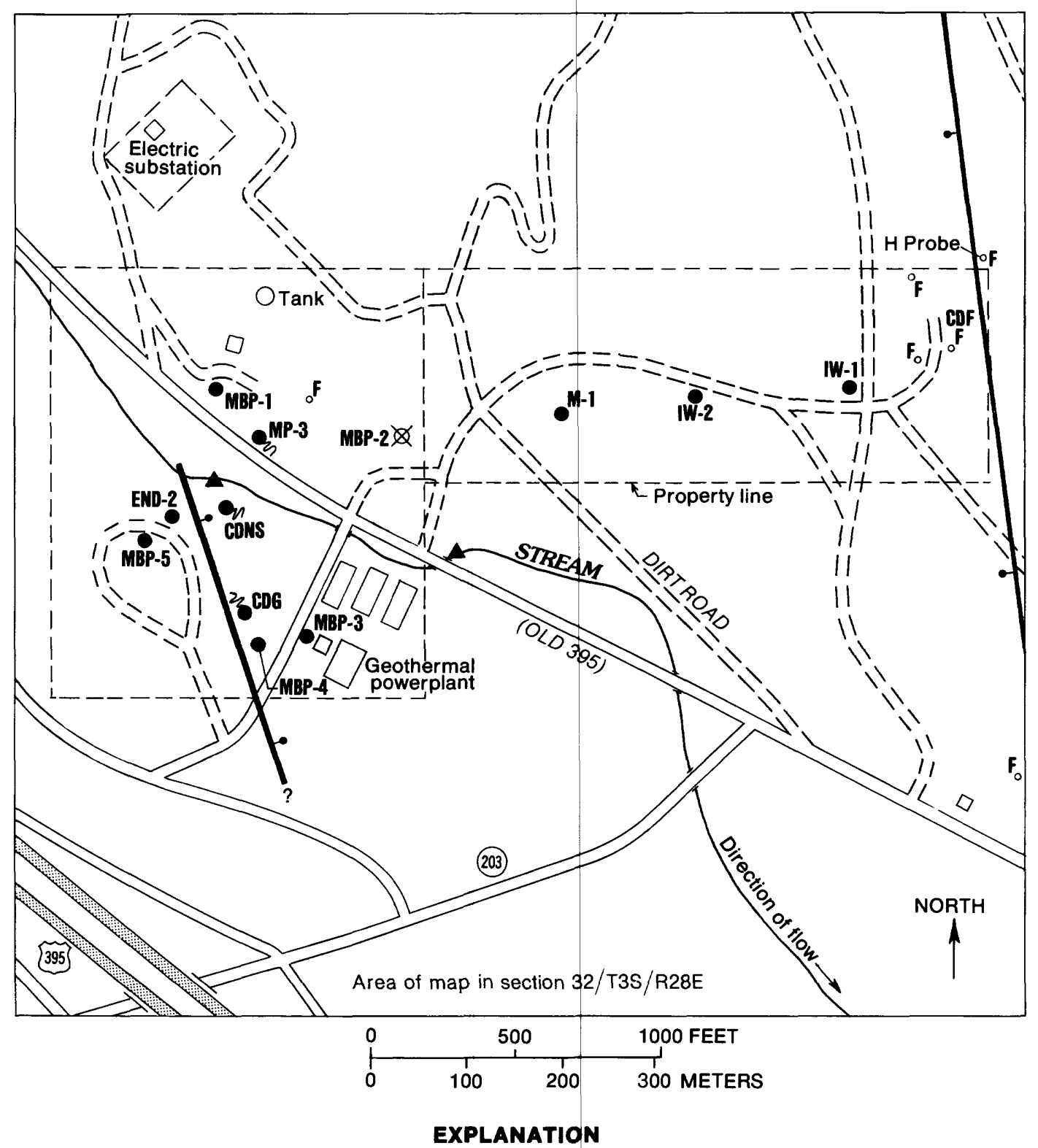

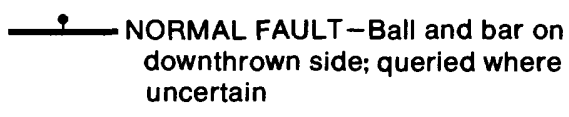

WELL AND DESIGNATION

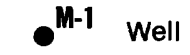

MBP-2 $\bigotimes$ Destroyed well
A SURFACE-WATER MONITORING SITE

CDG THERMAL SPRING AND DESIGNATION of Fumarole

FIGURE 3. - Casa Diablo area showing location of thermal springs, fumaroles, wells, and surface-water monitoring sites. 
Discharge from the lower area occurs from high-chloride, neutral-pH thermal springs. Chemical analyses of waters from these springs are given in table 1. Most of the thermal-water discharge from this area is contributed by the Casa Diablo geyser (CDG in fig. 3), which consists of several vents with pulsating flows of water and steam. These features are actually fountaining or jetting hot springs rather than true geysers. During 1985, stage records were maintained at a weir above and a flume below the area of thermal-spring flow west of old Highway 395. The mean daily difference in flow between these two sites represents the total flow of thermal water from this area (fig. 4 and table 6). During 1985, most of the flow at the flume was derived from the thermal springs. Also plotted in figure 4 is the total mean daily production rate from four wells that supply hot water for binary electric-power production at the Mammoth Pacific Geothermal Power Plant. Production data for wells MBP-1, $-3,-4$, and -5 were provided by Bill Asper, powerplant site manager for the Ben Holt Company, Pasadena, California.

Comparison of spring-flow and well-production records, along with visual observation of changes in spring activity, indicates a general correlation between increasing well production and decreasing spring flow through mid-August 1985. Prior to mid-August, significant increases in well production were followed within periods of hours to days by significant decreases in spring flow. After mid-August, the average daily spring flow remained relatively constant at levels approximately five times greater than minimum flows recorded during previous periods of sustained high well discharge. Spring flow from the Casa Diablo geyser after mid-August was also characterized by significant cyclic fluctuation over periods of about 4 hours. The causes of this apparent change in the correlation of spring flow and well production are as yet unknown.

Water samples were collected on five occasions from surface-water sites above and below the inflow of thermal water from the Casa Diablo thermal springs. Chloride and boron concentrations determined for these samples, along with the corresponding flow measurements, allow calculation of the chemical flux contributed by the thermal springs west of old Highway 395. Dividing the difference in chemical flux between upstream and downstream sites by the average $C l$ and $B$ concentrations in the thermal springs yields an estimate of the instantaneous discharge of the springs. These estimates are given below.

\begin{tabular}{lccc}
\hline \multicolumn{4}{c}{ Calculated spring flow $(\mathrm{L} / \mathrm{s})$} \\
\hline Date & From & From & Measured spring flow \\
& Cl flux & B flux & 32.3 \\
\hline $01 / 22 / 85$ & 36.0 & -- & 27.5 \\
$02 / 03 / 85$ & 30.9 & 30.4 & 1.99 \\
$03 / 19 / 85$ & 2.67 & 2.81 & 25.8 \\
$04 / 25 / 85$ & 28.1 & 30.7 & 10.2 \\
$10 / 18 / 85$ & 12.1 & 13.0 & 2 \\
\hline
\end{tabular}

Values of $\mathrm{Cl}$ and $\mathrm{B}$ concentration in the spring waters were assumed for these calculations to be $270 \mathrm{mg} / \mathrm{L}$ and $11 \mathrm{mg} / \mathrm{L}$, respectively. In each case the 
average calculated spring flow is greater than the measured spring flow. The difference results primarily from evaporation and infiltration of a fraction of the spring water before it reaches the downstream flume. These data suggest that losses between the upstream and downstream sites amount to 10 to 30 percent of the total thermal-spring discharge.

Additional thermal-fluid discharge in the vicinity of Casa Diablo occurs at Meadow Spring, Colton Spring, and Chance Spring. Water discharges seasonally from several seeps at Meadow Spring (MS in fig. 2) at temperatures near $60{ }^{\circ} \mathrm{C}$. During autumn 1985 no surface discharge was observed from this area. At Colton Spring (CS in fig. 2), across Mammoth Creek from the Sheriff's Substation, a 45-degree $V$-notch weir was installed in August, and the five measurements of flow given below were made.

\begin{tabular}{cc|c}
\hline Date & Time & $\begin{array}{c}\text { Discharge } \\
(\mathrm{L} / \mathrm{s})\end{array}$ \\
\hline $08 / 29 / 85$ & 1520 & 0.59 \\
$09 / 07 / 85$ & 1400 & 0.59 \\
$09 / 24 / 85$ & 1320 & 0.74 \\
$10 / 18 / 85$ & -- & 0.66 \\
$12 / 12 / 85$ & 0900 & 0.83 \\
\hline
\end{tabular}

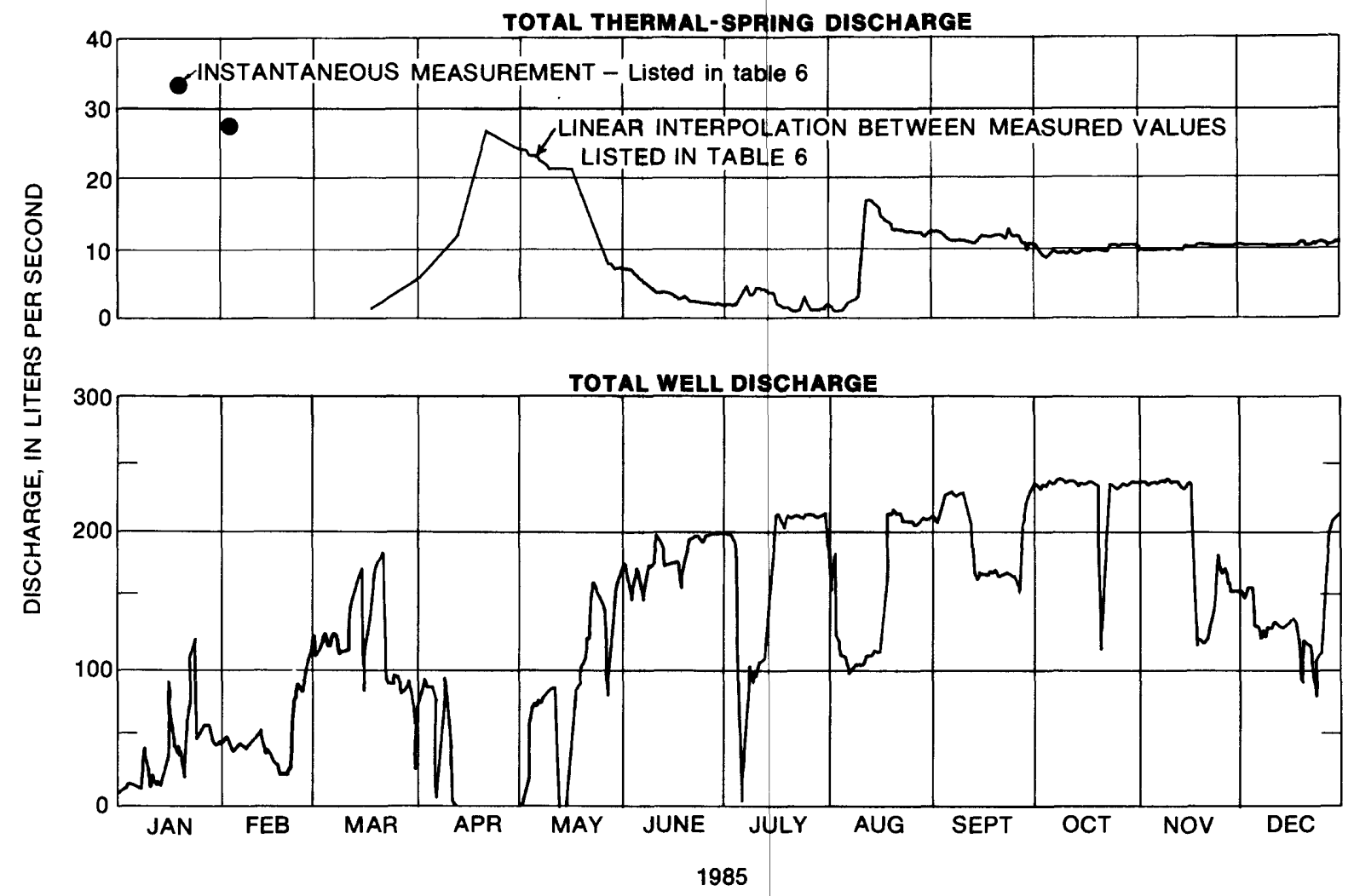

FIGURE 4. - Total thermal-spring discharge and total well discharge at Casa Diablo during 1985. 
Two areas of weak steam discharge on the hillside above Colton Spring continued to be active during 1985. Chance Spring, as distinct from Chance Meadow Spring, issues from the edge of a basalt flow at temperatures near $20{ }^{\circ} \mathrm{C}$ and flows directly into Mammoth Creek between the Mammoth Creek flume and the Sheriff's Substation. Water discharges from numerous vents in the area, access to which is made difficult by a thick brush cover. This area was not visited or sampled in 1985.

\section{Fish Hatchery Area}

The Fish Hatchery area is located in the south-central part of the caldera and includes parts of secs. 34 and 35, T. 3 S., R. 28 E. (fig. 2). A detailed map of the area (fig. 5) shows the location of only large springs; however, numerous smaller springs dot the area and in total may contribute significant flow to Mammoth Creek.

Two springs in the area are equipped with monitoring instrumentation that collects and records data at 15-minute intervals or on a continuous chart. For the Fish Hatchery spring group H-II, III, stage is sensed by a float and is recorded on a Leupold-Stevens type A-71 graphic recorder and a Fisher-Porter digital recorder at a point about 500 feet downstream of the spring vent. The control at this site is a 4-foot Cipolletti weir, which was installed February 22, 1985. Table 7 gives the mean daily discharge, in liters per second $(\mathrm{L} / \mathrm{s})$, for the period February 22 to December 31, 1985, as computed from the standard rating for Cipolletti weirs. Periods during parts of March, November, and December lack records due to ice in the stilling wel1. Daily mean discharges range from 139 to $155 \mathrm{~L} / \mathrm{s}$, and monthly mean discharges range from 139 to $153 \mathrm{~L} / \mathrm{s}$. Figure 6 shows these data graphically.

Water temperature and specific conductance are also recorded for spring group H-II, III using a U.S. Geological Survey minimonitor and Leupold-Stevens digital recorder with a sampling frequency of 15 minutes. The temperature and specific-conductance sensors are located in the main pool adjacent to the spring-vent area. Both the temperature and specific conductance are remarkably constant throughout the year. Temperature varies less than $0.5{ }^{\circ} \mathrm{C}$ from an average of about $11.5{ }^{\circ} \mathrm{C}$, and specific conductance varies by less than 5 microsiemens from an average of about 165 microsiemens per centimeter at $25^{\circ} \mathrm{C}$.

The other spring being monitored by the U.S. Geological Survey in this area is Hot Bubbling Pool (also referred to as Casa Diablo Hot Pool) (fig. 5). As its name implies, this spring is a hot pool of water supplied by discharge from numerous small vents around its perimeter and probably from several larger subaqueous vents. The pool changes in surface area through the seasons but is approximately 50 feet by 100 feet and has no liquid surface discharge. Pool stage and water temperature are monitored at this site and recorded on a Leupold-Stevens digital recorder at 15-minute intervals. Stage is sensed using a Schaevitz model P3061 transducer that senses gas pressure in a tube with an open end set below the water surface. The tube is supplied with a constant volumetric flow of nitrogen from a compressed-gas cylinder. Voltage output from the transducer is converted to 

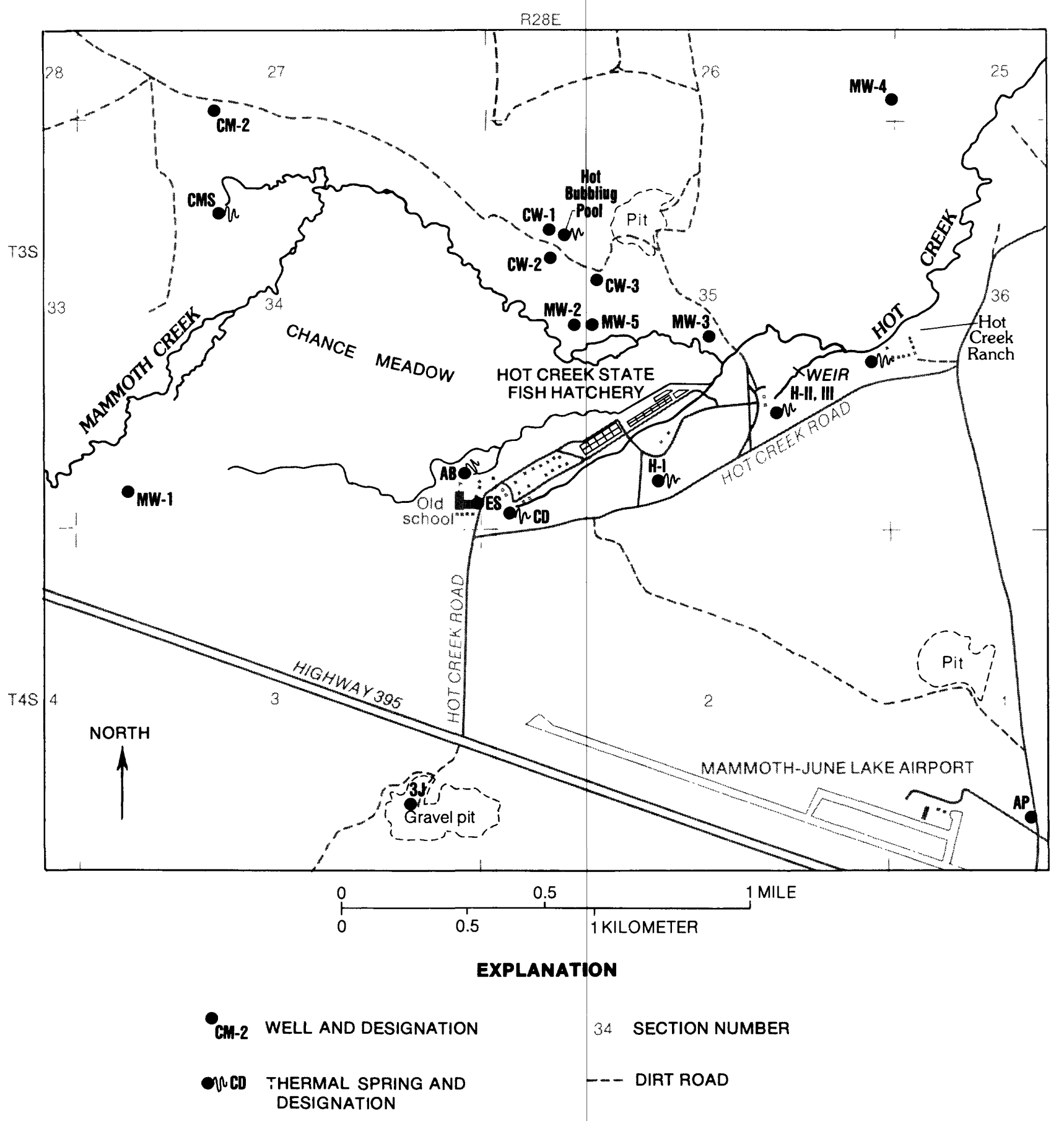

FIGURE 5. - Chance Meadow area showing location of wells and thermal springs in the vicinity of the Fish Hatchery and Hot Bubbling Pool. 


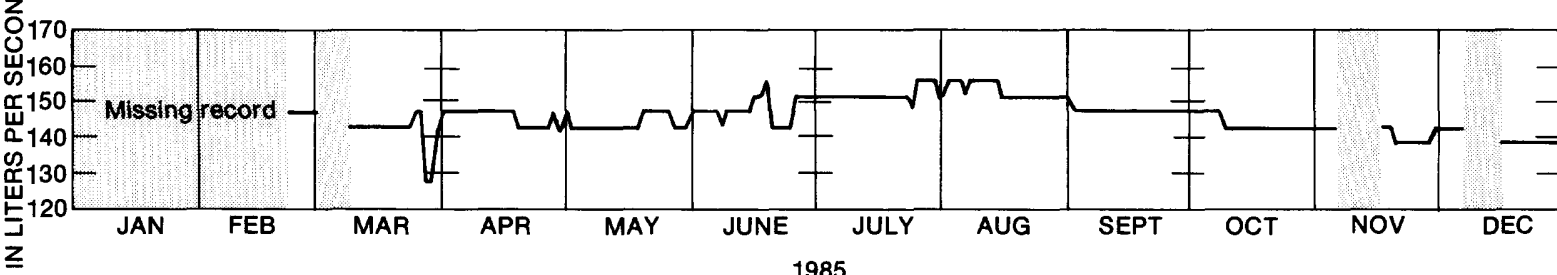

FIGURE 6. - Mean daily discharge of thermal-spring group H-II, III at the Fish Hatchery during 1985.

an equivalent height of water column over the tube orifice by a U.S. Geological Survey minimonitor. Temperature is sensed with a platinum resistance device and output is converted to degrees Celsius by the minimonitor.

Pool stage has been recorded since 1983 and is noted to fluctuate in response to the annual hydrologic cycle. The highest stage during 1985 was recorded in April (fig. 7), a time of recharge from snowmelt, and a steady decline was recorded from July through December when recharge is low. Pool stage also has pronounced cyclical behavior, with a period ranging between 3 and 5 hours (fig. 8). The amplitude of these fluctuations is on the order of 1.0 to 1.5 feet. The cyclical fluctuation in stage several times per day is similar to geyser activity. The temperature record shows that thermal-water inflow causes a rise in stage. Stage peaks when sufficient hydrostatic head blocks further inflow. Stage then declines, possibly due to subsurface flow of water laterally away from the pool. The variation in frequency and amplitude of the cyclical fluctuations may be related to changes in barometric pressure. Higher barometric pressure corresponds to shorter frequency and smaller amplitudes.

Water levels in a well (CW-1) about 100 feet west of Hot Bubbling Pool were recorded for a few weeks during March and April 1985 using the same type of instrumentation that was used for Hot Bubbling Pool. Figure 8 shows the water-level record acquired. Comparing the record from the well to that of the pool, the same type of oscillatory water-level fluctuations, with a period of about 5 hours, is evident. There is a phase shift between the two records; when the pool stage is at a local maximum the water level in the well is at or near a local minimum. The record from well CW-1 shows a more pronounced barometric influence than the Hot Bubbling Pool record. The response is that of a well tapping a confined aquifer in which high barometric pressure depresses the water level and low barometric pressure allows the water level to rise. 

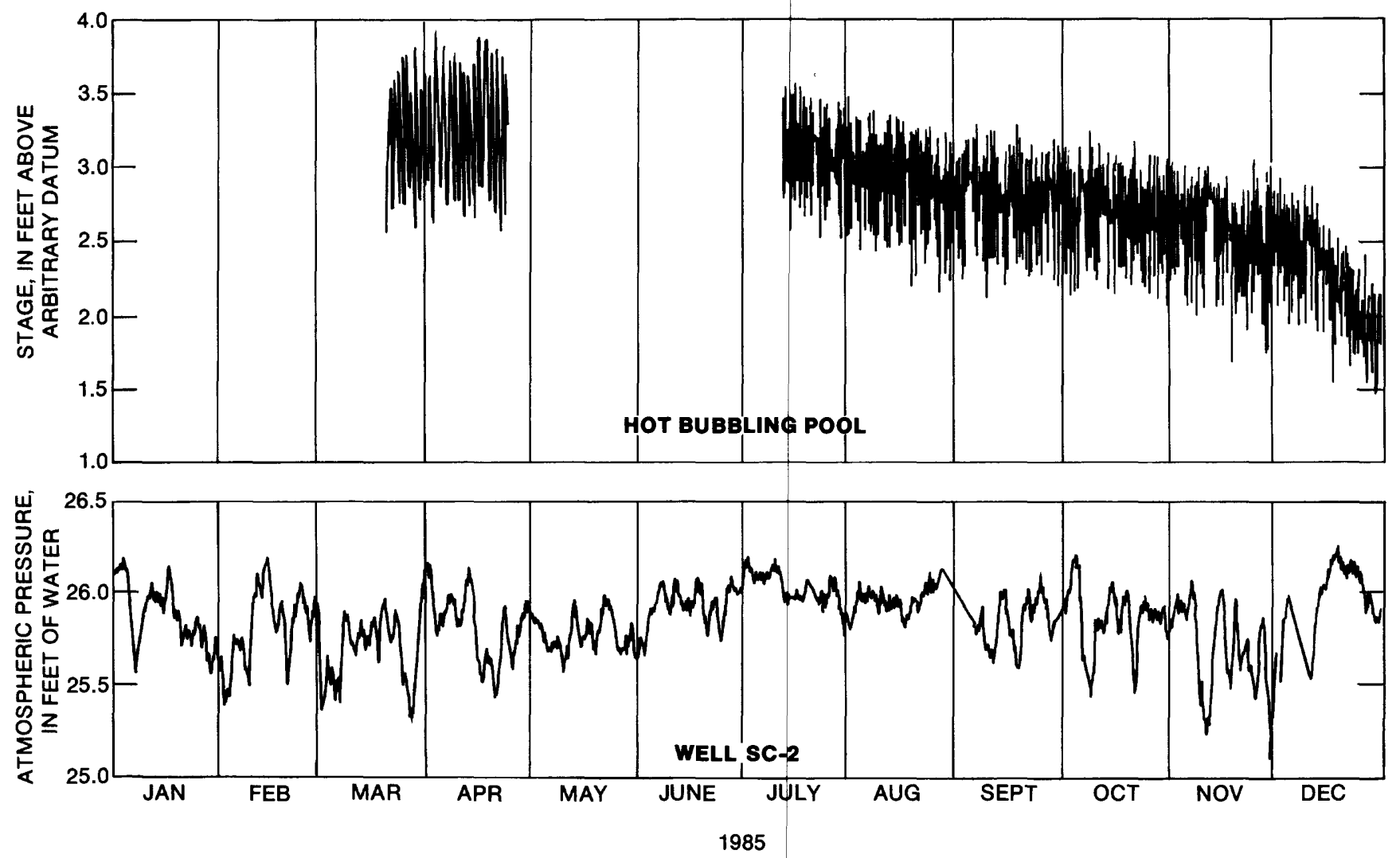

FIGURE 7. - Stage record for Hot Bubbling Pool and atmospheric pressure for well SC-2 during 1985. 

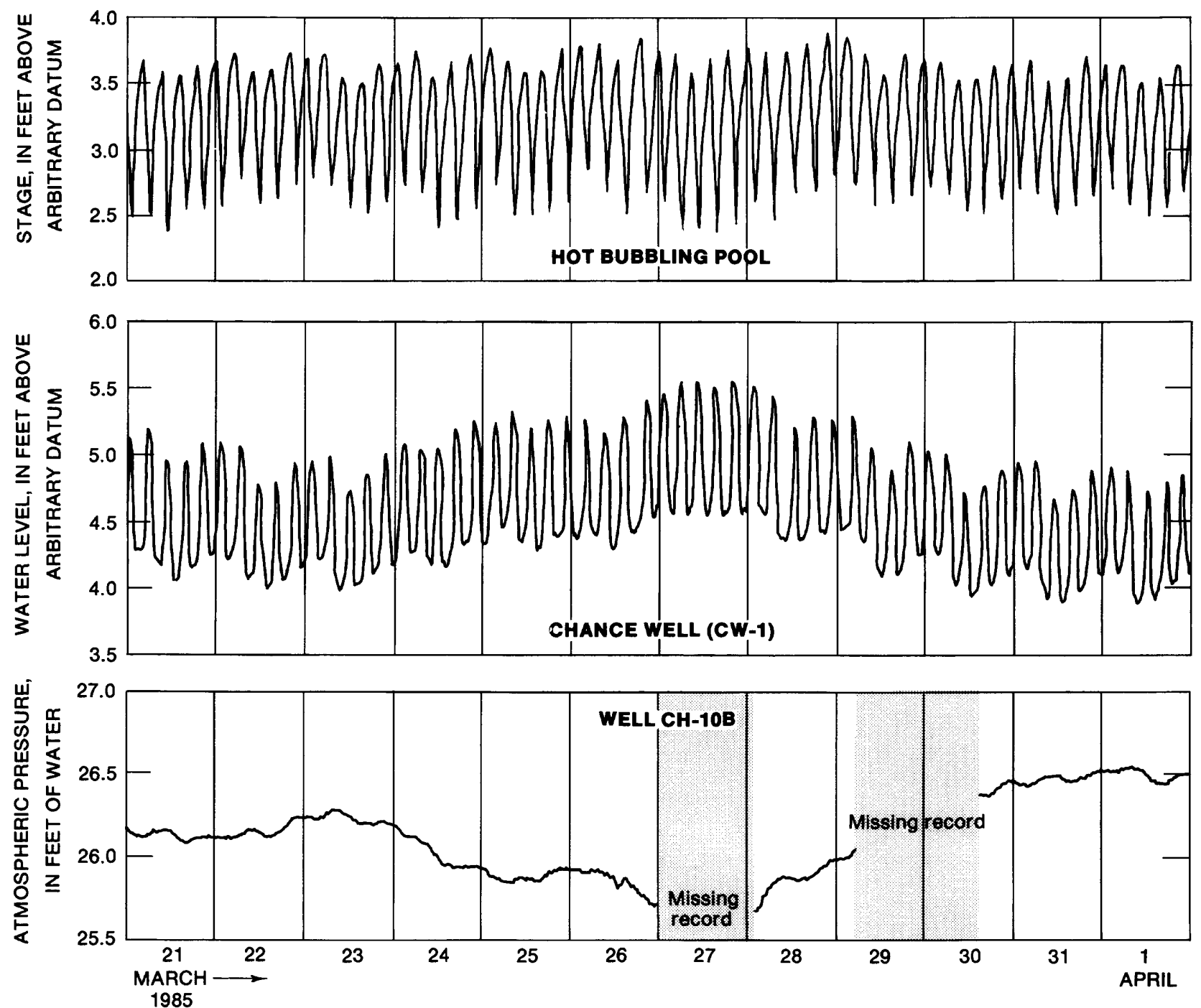

FIGURE 8. - Hydrographs for Hot Bubbling Pool and the Chance well (CW-1), and atmospheric pressure measured at well $\mathrm{CH}-10 \mathrm{~B}$ for a 12-day period in March and April 1985. 
The Little Hot Creek Springs area is in the central part of the caldera (fig. 2) in the northwest quarter of sec. 13, T. $3 \mathrm{~S} ., \mathrm{R} .28 \mathrm{E}$. In this area numerous springs discharge thermal water from an area of about 3 acres (fig. 9). The thermal waters provide perennial flow for Little Hot Creek, whose headwaters begin in Little Antelope Valley. Little Hot Creek flows eastward to join the Owens River north of Lake Crowley.

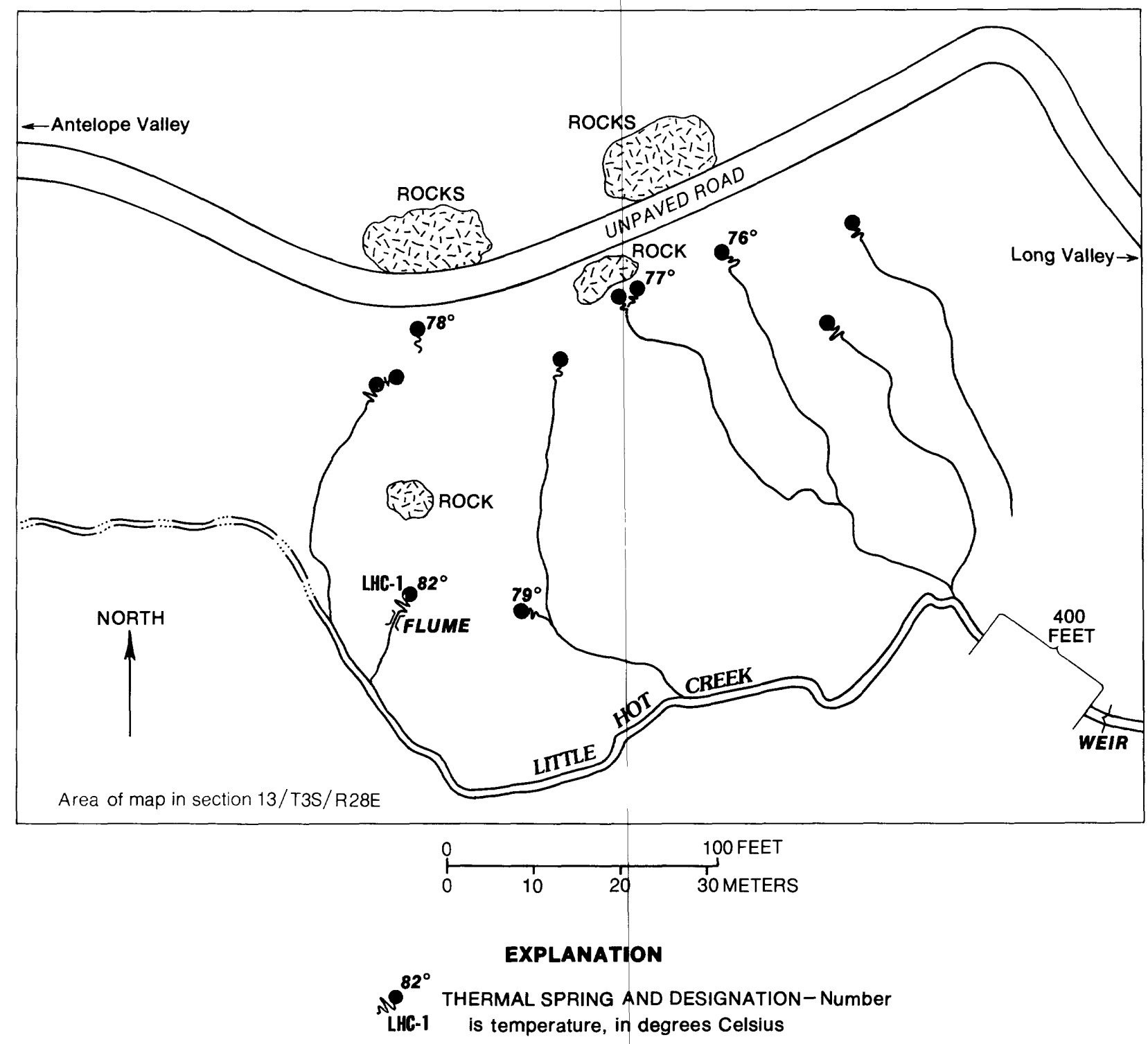

FIGURE 9. - Little Hot Creek thermal area showing location of thermal springs and gaging sites. 
The flow of Little Hot Creek below the thermal springs was monitored with a Leupold-Stevens A-71 graphic recorder that sensed stream stage with a float. Control for the site was provided by a 90-degree V-notch weir. Discharge was computed from a standard rating (table 8). A 3-inch modified Parshall flume was set up to measure the flow of one of the larger individual thermal-spring vents (LHC-1, fig. 9). The stage was sensed with a float and recorded on a Leupold-Stevens model A-71 graphic recorder. Standard tables were used to convert stage to discharge (table 9). A precipitation gage (Belfort Instrument Company universal raingage) was also set up at this site; the precipitation record for 1985 is shown in table 10.

The mean daily discharges of Little Hot Creek and the individual thermal spring (LHC-1) and daily precipitation totals are shown graphically for 1985 in figure 10. The discharge record for Little Hot Creek shows very minor seasonal variations, influenced by snowmelt and precipitation events. Discharge for spring vent LHC-1 shows virtually no change during the period.
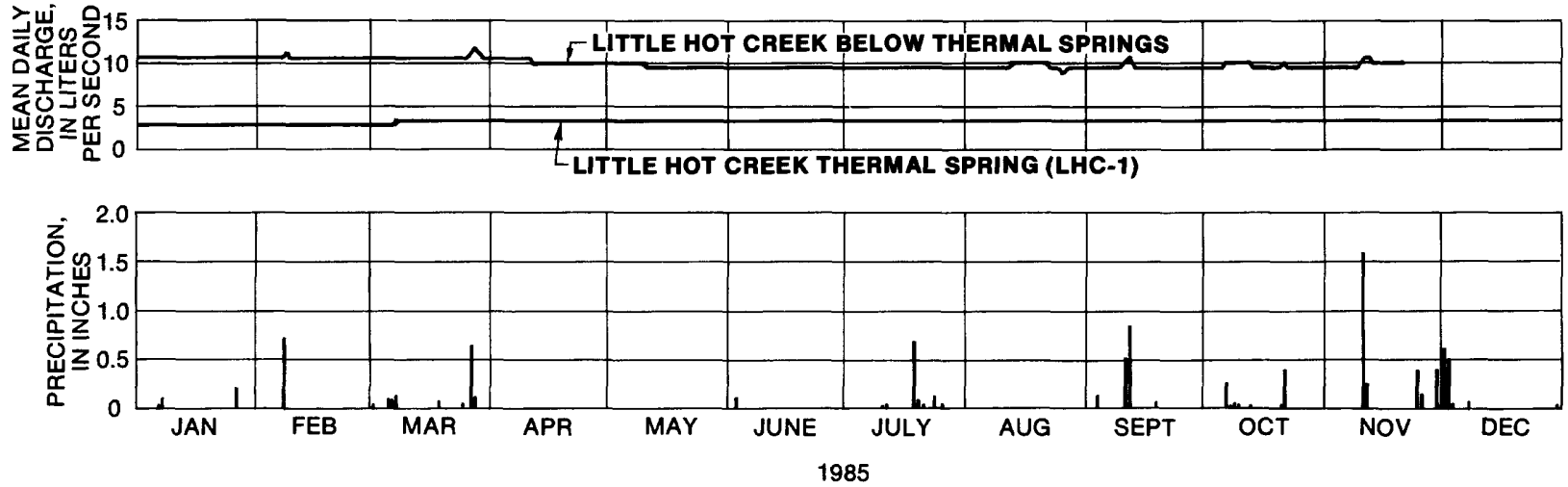

FIGURE 10. - Streamflow and precipitation during 1985 at gaging site below the thermal springs along Little Hot Creek, and flow from thermal spring LHC-1. (Location of sites shown in fig. 9.)

\section{Hot Creek Gorge}

Hot creek gorge (fig. 2; sec. 25, T. 3 S., R. 28 E.), which has approximately 100 feet of relief, was cut by Hot creek into the 0.28-million-year-old Hot Creek Rhyolite (Bailey and others, 1976). Numerous thermal springs discharge into the creek along a l-mile section of the gorge bounded by northwest-trending faults that form a graben within the rhyolite flow (fig. 11). Temperatures of individual springs in this reach range from ambient to $94{ }^{\circ} \mathrm{C}$, and are generally highest near the eastern graben fault. Most of the spring discharge, including the flow from two large (unnamed) vents formed in the bed of the creek, occurs within about 500 feet of the bridge at the swimming area (fig. 12). Measuring sites used to make indirect 


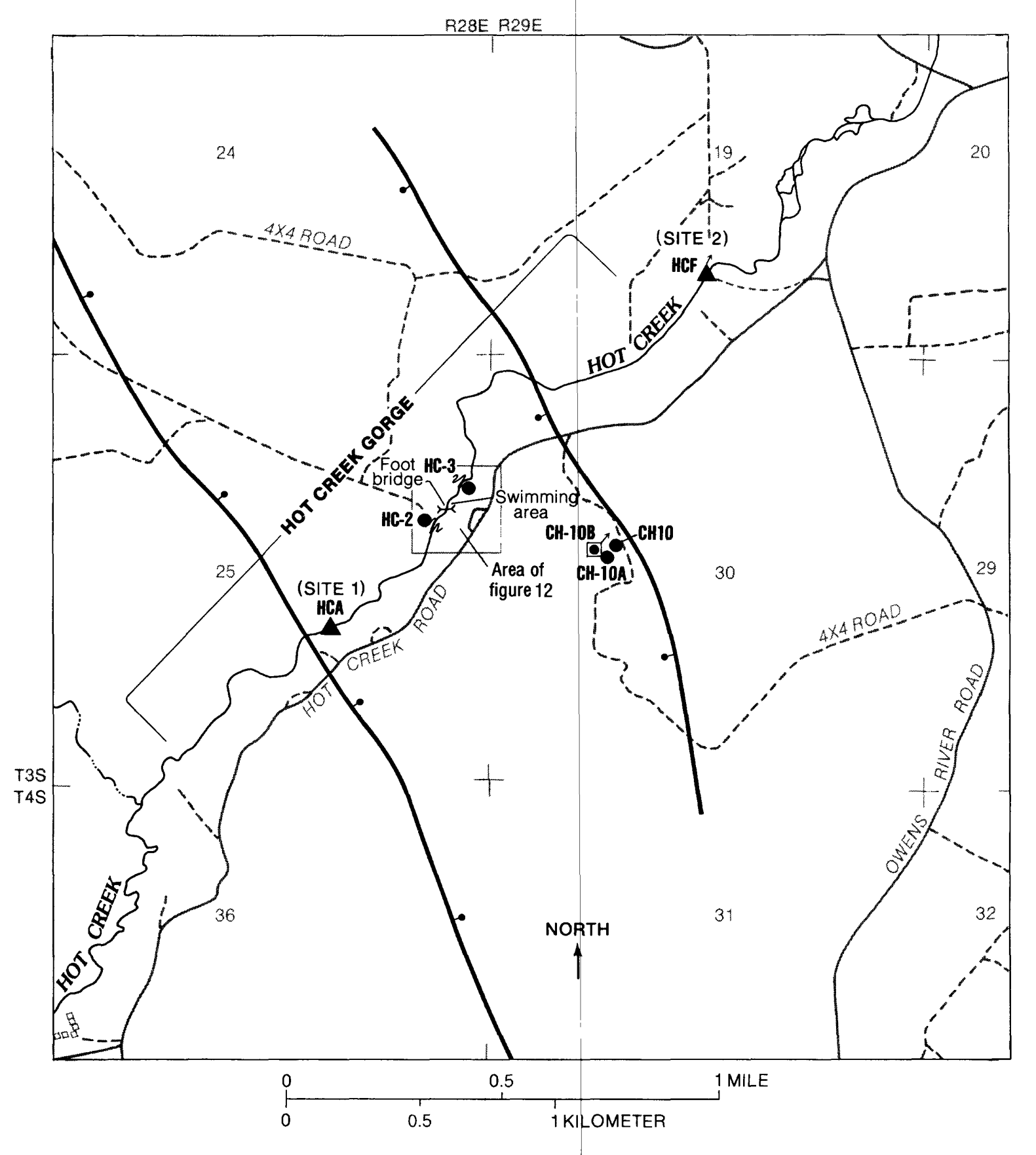

\section{EXPLANATION}
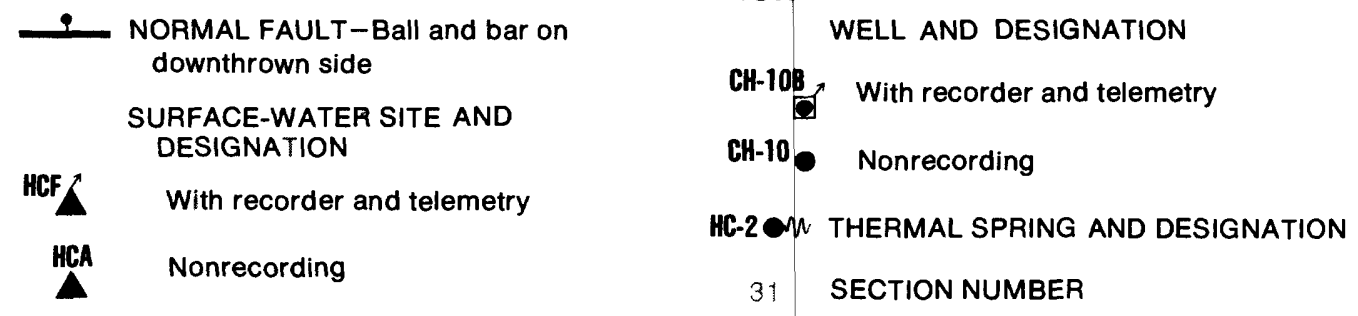

FIGURE 11. - Hot Creek gorge and vicinity showing location of wells, thermal springs, and surface-water sites. 


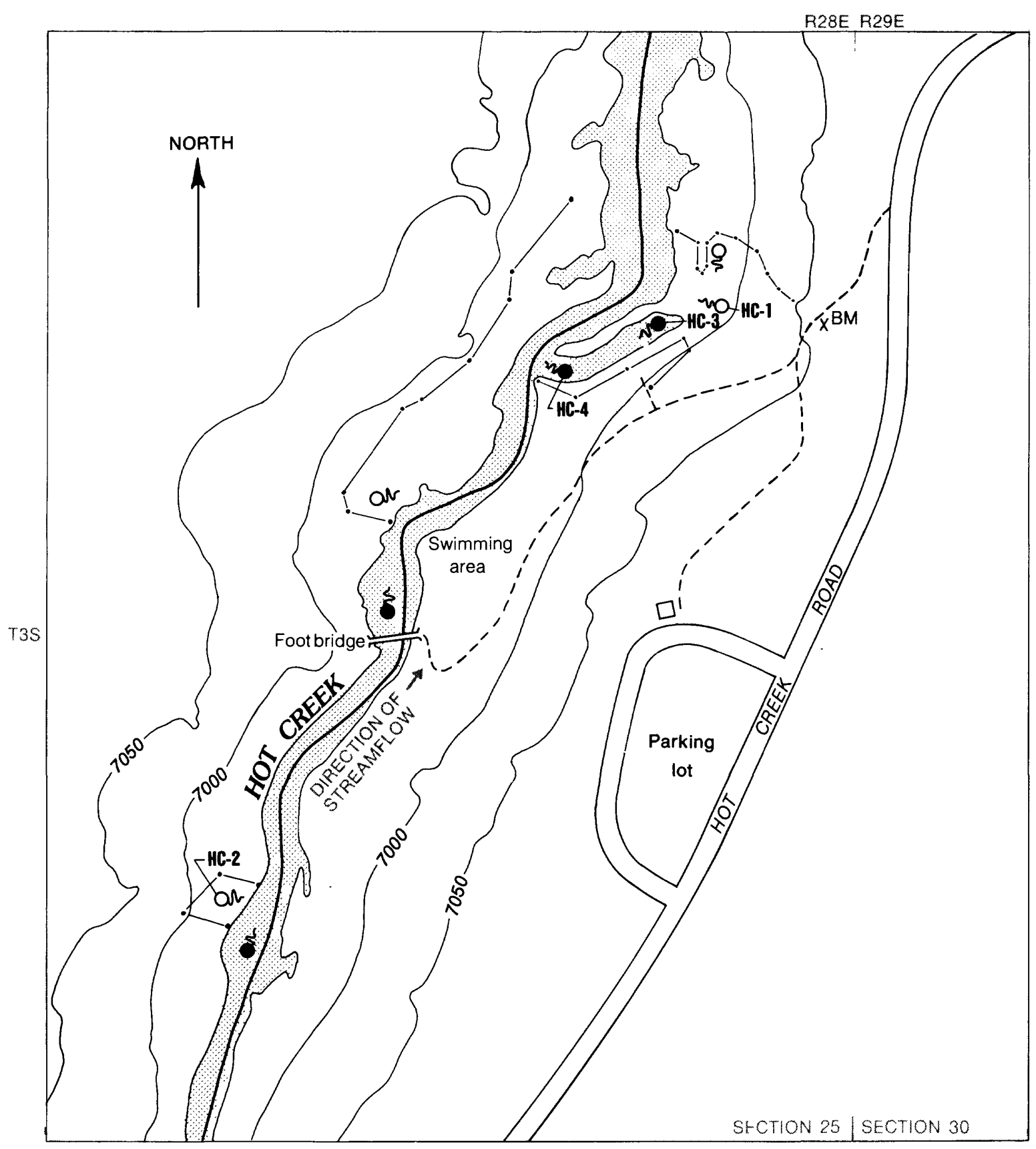

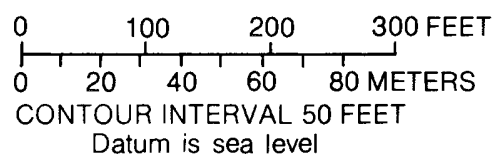

EXPLANATION

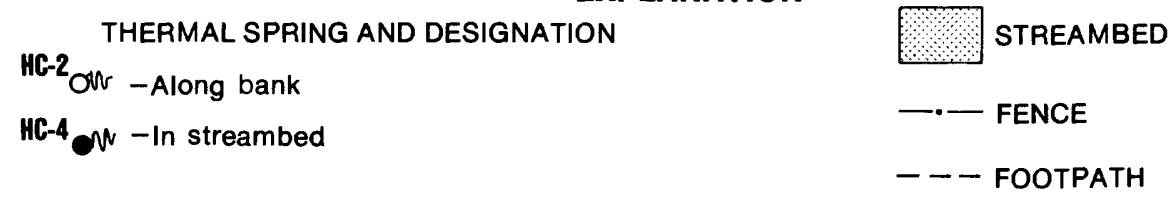

FIGURE 12. - Section of Hot Creek gorge showing location of thermal springs. 
determinations of total thermal-water discharge in the gorge are site 1 (HCA), approximately 0.3 mile upstream from the bridge, and site 2 (HCF), 1 mile below the bridge at the concrete flume built by Los Angeles Department of Water and Power. The location of these sites is shown in figure 11.

Measurements made at site 1 include periodic stream gaging and chemical sampling of Hot Creek. Stream gaging was done by wading with a current meter at a marked section. Water samples for determinations of chloride and boron concentrations were collected from near the midsection of the stream.

Measurements at site 2 include periodic water sampling as outlined above and observations of stream stage at the flume. Current-meter measurements of streamflow at this site during the 1983-85 period enable a revised rating curve to be established for the flume. Computations based on this revised (RI) rating curve yield streamflow values that are approximately 10 percent less than values obtained from the standard rating for this structure, a 10-foot modified Parshall flume.

The continuous record of stream stage, temperature, and specific conductance begun at site 2 in September 1983 (Farrar and others, 1985) was continued during 1985. Measurements of stream temperature and conductance were recorded at 15-minute intervals and both stored onsite (using a U.S. Geological Survey minimonitor data logger) and telemetered by satellite. Measurements of stream stage, recorded at 15-minute intervals, only were stored onsite. To relate specific conductance (SC) to chloride and boron concentrations, the following relations were established from analyses of 28 samples collected in 1985 .

$$
\begin{aligned}
& C l(\mathrm{mg} / \mathrm{L})=0.1312 \times S C-23.1 \\
& B(\mathrm{mg} / \mathrm{L})=0.005149 \times S C-0.659
\end{aligned}
$$

These relations differ somewhat from those given by Farrar and others (1985) that were based on analyses of samples collected during 1982-84. The 1982-84 sample set includes several values from periods of streamflow significantly greater than observed in 1985. The differences in Cl-B-SC relations result primarily from the lack of samples collected in 1985 during conditions of such high streamflow. The relations shown above provided a better fit to the 1985 data.

Calculated values of chloride and boron flux and equivalent thermal-spring discharge for Hot Creek are given in table 11 . In the equations shown for calculation of thermal-spring discharge, $220 \mathrm{mg} / \mathrm{L}$ and 10 $\mathrm{mg} / \mathrm{L}$ are the average $\mathrm{Cl}$ and $\mathrm{B}$ concentrations in thermal-spring waters in Hot Creek gorge. (See table 1.)

For the seven occasions when flux determinations were made at both sites 1 and 2, the average calculated value of total thermal-spring discharge is $244 \mathrm{~L} / \mathrm{s}$ from the chloride data and $243 \mathrm{~L} / \mathrm{s}$ from the boron data. Close agreement between these two values and the size of the standard deviations about the means indicate that errors associated with the chemical analyses were small and that variations in spring discharge during August-December 1985 were relatively minor. For comparison, the average value of thermal-spring discharge based on eight chloride-flux measurements between October 1973 and November 1984 is 271 L/S (Farrar and others, 1985). The 
difference between this value and the 1985 values is due to the use of the standard rating curve for streamflow at the flume for pre-1985 data, which results in overestimation of streamflow by about 10 percent.

The flux of chloride and boron at site 1 upstream from the gorge thermal springs is most likely derived from thermal springs to the west of the gorge. For August-December 1985, chloride flux at site 1 averaged $8,530 \mathrm{mg} / \mathrm{s}$. This is equivalent to an input of $32 \mathrm{~L} / \mathrm{s}$ of thermal-spring flow with chloride concentration equal to that of the springs at Casa Diablo $(270 \mathrm{mg} / \mathrm{L})$. Table 12 shows data on chloride discharge from thermal springs west of the gorge for which total spring flow was measured or estimated in 1985. The total Cl flux contributed by these springs to Mammoth Creek and Hot Creek is close to the average $\mathrm{Cl}$ flux measured at site 1 in the gorge during autumn 1985 . A similar result was obtained for the boron flux.

Chloride flux measured at site 1 in May 1985 is approximately twice as high as the average noted above. This is consistent with results from Farrar and others (1985) for flux measurements made in spring 1984; higher Cl flux in the spring was attributed by these authors to release of $\mathrm{Cl}$ from storage within the drainage basin west of the gorge. One additional source of $\mathrm{Cl}$ above the gorge is Chance Spring (CHS in fig. 2) near the Sheriff's Substation. Although Sorey and Lewis (1976) estimated the flow of this $20{ }^{\circ} \mathrm{C}$ spring at $23 \mathrm{~L} / \mathrm{s}$, visual observations and preliminary measurements of temperature and $\mathrm{Cl}$ content in Mammoth Creek above and below Chance Spring in 1986 suggest that the total spring flow from this area may be 10 times higher. Data from Farrar and others (1985) indicate a Cl concentration of 31-55 $\mathrm{mg} / \mathrm{L}$ in the spring water. Thus its contribution of $\mathrm{Cl}$ to Mammoth Creek could double the estimated total $\mathrm{Cl}$ discharge from springs listed in table 12.

Results of continuous measurements of flow and conductance at site 2 during 1985 are plotted in figure 13 in terms of mean daily values of streamflow and chloride flux. Values of chloride flux from the periodic measurements (table 11) are also plotted in figure 13. Not plotted is the continuous record of chloride flux for June 6-December 31 because data from the conductivity probe were not reliable for that period. The increase in streamflow during late spring and early summer is related to snowmelt rather than to direct runoff from precipitation (table 13). The streamflow hydrograph is similar to that observed in 1984, except that the rate of increase in flow during the snowmelt period that begins in May was less rapid in 1985 and peak flows (near 3,500 L/s) were smaller than 1984 peak flows $(5,000 \mathrm{~L} / \mathrm{s})$.

Correlation of increasing chloride flux with increasing streamflow during late spring-early summer was not as obvious or as prolonged in the continuous record for 1985 as for 1984. This may be related to the differences in runoff noted above.

Small differences between mean daily-flux values and the periodic measurements of chloride flux can be attributed to diurnal variations in flux and to variability in the Cl-SC correlation. Errors associated with the conductance probe used in the flume, the field meter used to check readings from the probe, and laboratory determinations of specific conductance result in a level of precision in monitoring the stream conductance of about \pm 5 
percent under the best conditions. This implies a precision of \pm 8 percent in calculated values of $\mathrm{Cl}$ and $\mathrm{Cl}$ flux. Other factors, including sediment' and algal accumulation on the flume probe and errors in conductance readings with the field meter and in laboratory determinations of conductance, can further degrade the accuracy of the continuous measurements of $C l$ flux. In spite of these difficulties, the continuous flux record at the flume should be maintained, because it makes possible the early detection of significant changes in thermal-spring discharge that may be precursors to tectonic or magmatic events.
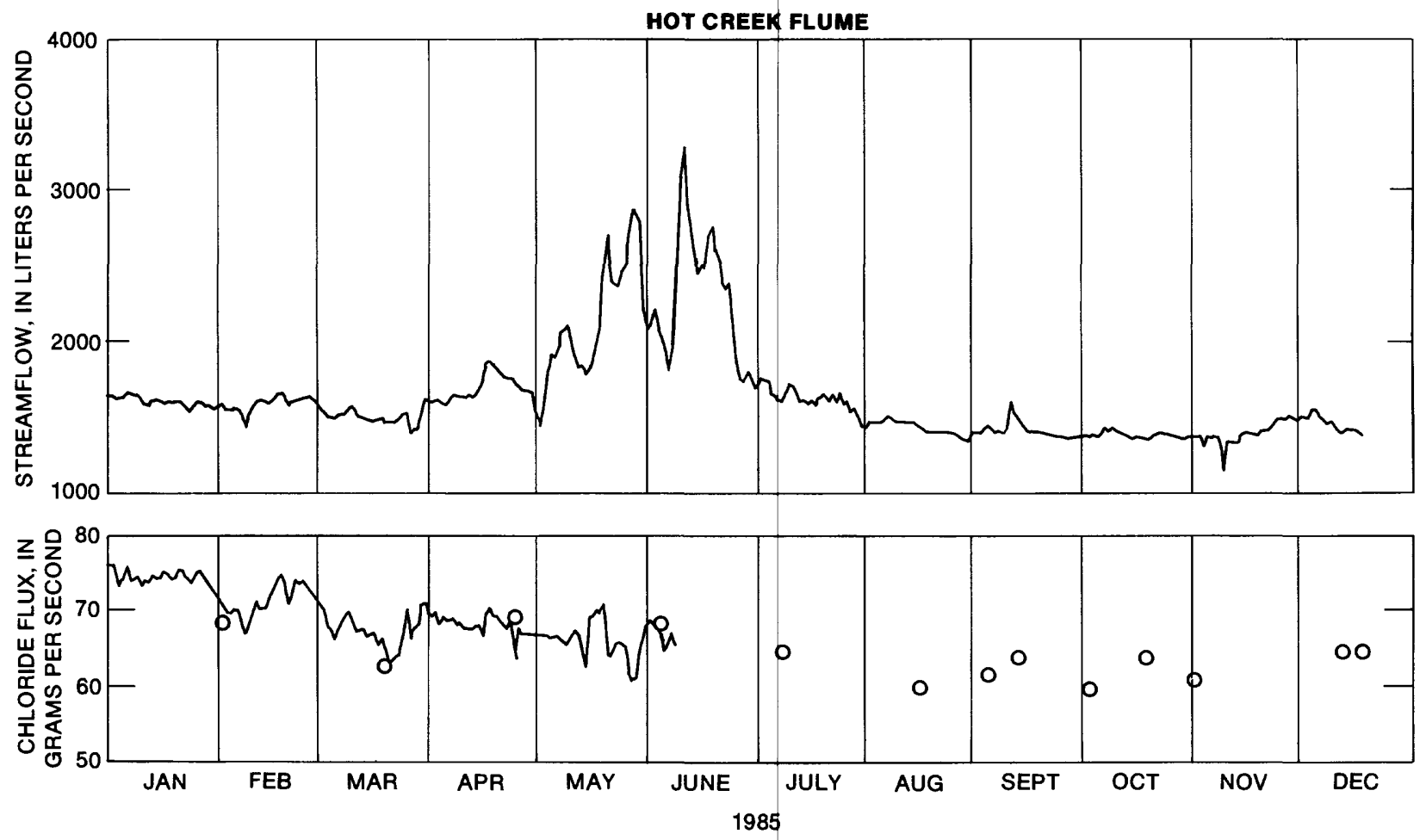

\section{EXPLANATION}

O INSTANTANEOUS MEASUREMENT

FIGURE 13. - Streamflow and chloride flux during 1985 at the Hot Creek flume based on values of river stage and specific conductance recorded at 15 -minute intervals and averaged over 24-hour periods. 


\section{Laurel Spring}

Laurel Spring (LS) is located along the southern boundary of the caldera, probably within the ring-fracture zone, in sec. 9, T. 4 S., R. 28 E. (fig. 2). The spring consists of one main vent area, in which a shallow pool about 5 feet across is fed from several sources around its perimeter. The water wells up or flows out from colluvium near the base of Laurel Mountain at an altitude of 7,200 feet. A 90-degree $V$-notch weir located in the discharge channel about 30 feet from the vent pool controls stage, which is recorded using a Stevens type-F stage recorder. The stage record is converted to discharge volume (table 14) using the standard rating for a V-notch weir. Figure 14 shows the nearly constant discharge rate for this spring for the year 1985. Discharge ranges from 34 to $37 \mathrm{~L} / \mathrm{s}$; the lower discharges through late summer and autumn may indicate a slight seasonal variation.

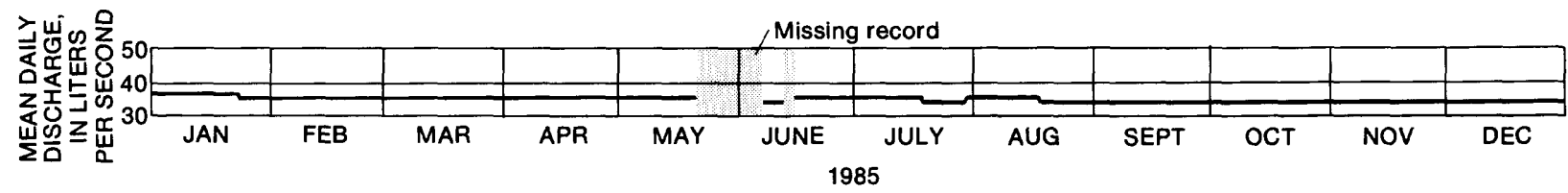

FIGURE 14. - Discharge during 1985 at Laurel Spring gaging site. 
Fluctuations in ground-water level within the caldera were determined from periodic measurements of the depth to water in some wells and continuous measurements of fluid pressure above sensing elements in other wells. In most cases, wells selected for periodic water-level measurement are perforated within the shallow nonthermal ground-water system, and changes in depth to water in these wells are related to seasonal variations in ground-water recharge and discharge. Wells selected for continuous water-level measurement are perforated within aquifers containing thermal ground water or within deeper nonthermal aquifers.

Well Inventory and Test Drilling

Information on wells not included in the previous well inventory by Farrar and others (1985) is given in table 15. Well-construction and altitude information for wells drilled for the Mammoth/Chance Geothermal Project was provided by Higginson and Barnett Consulting Engineers, Salt Lake City, Utah, and by TRIAD Engineering, Mammoth Lakes, California. Township-range-section locations follow the numbering system shown in figure 15. The number and letter preceding the slash, as in $3 S / 29 E-2 A$, indicate the township (T. $3 \mathrm{~S}$.$) ; the number and letter following the slash$ indicate the range (R. $29 \mathrm{E}$.); the number following the hyphen indicates the section (sec. 2); and the letter following the section number indicates the 40-acre subdivision of the section. Some numbers have a final digit, which is a sequence number for wells in the subdivision. The township and range lines are based on the Mount Diablo base line and meridian.

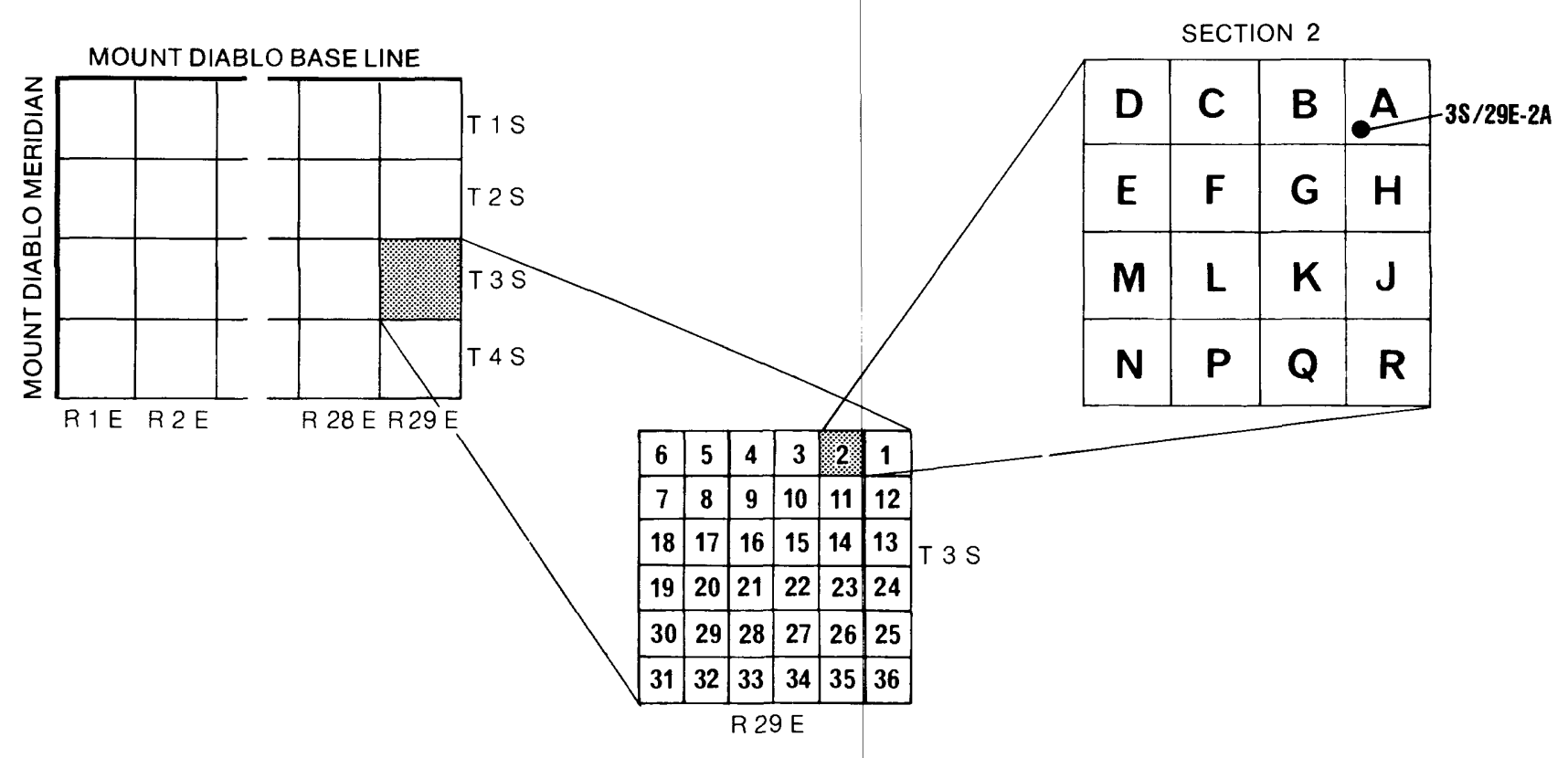

FIGURE 15. - Well-numbering system. 


\section{Periodic Water-Level Measurements}

Water-level data collected periodically in 1985 are given in table 16. Additional water-level data for these and other wells prior to 1985 are given by Farrar and others (1985), Lewis (1974), and California Department of Water Resources (1973). Wells CW-1 and CW-3, near Hot Bubbling Pool, show cyclic water-level fluctuations with amplitudes of 1 foot and periods of 3 to 8 hours. The fluctuations probably are related to the inflow and outflow of thermal water. Data for monitor wells MW-1, -2, $-3,-4$, and -5 may be influenced by low-permeability connections with the shallow ground-water system and by partial sediment filling in perforated sections of their casings.

\section{Continuous Water-Level Measurements}

Six wells were continuously monitored for water-level fluctuations during 1985 in an effort to detect deformation within the Long Valley caldera. In each of these wells except $\mathrm{CH}-10 \mathrm{~B}$, pressure transducers with a resolution of approximately 0.003 foot of water-level change were submerged less than 10 feet below the water surface for fluid-pressure measurements. At $\mathrm{CH}-10 \mathrm{~B}$, fluid temperatures of nearly $80^{\circ} \mathrm{C}$ required the use of a nitrogen-bubble gage attached to an uphole strain-bridge transducer with a resolution of about 0.02 foot. Apparent diurnal fluctuations in water level displayed in the records for $\mathrm{CH}-10 \mathrm{~B}$ of \pm 0.15 foot are probably caused by minor temperaturedependent gas leaks in the pressure-regulating system and by temperaturedependent-measurement error in the transducer itself. Atmospheric pressure also is recorded at each site. Wells $\mathrm{CH}-1, \mathrm{CH}-5, \mathrm{CH}-10 \mathrm{~B}$, and $\mathrm{SC}-2$ were equipped with satellite telemetry platforms that transmit data collected at 15-minute intervals. At wells LM and PLV-2, the data are recorded onsite at 15-minute intervals.

Water-level data from the wells are plotted in figures 16-21 in terms of depth to water below measuring point. Recorded water-level fluctuations were converted to depths to water and adjusted for drift and changes in transducer position (except at PLV-2) using periodic measurements made with a handheld electric sounder. At well PLV-2, the apparent rise in water level on June 3 is thought to have been caused by an inadvertent change made in position of the transducer level following a temperature-logging run. Atmospheric pressure is plotted in terms of equivalent water-level change at standard temperature and pressure. The atmospheric-pressure sensors at each site provide a resolution of approximately 0.3 millibars ( 0.01 foot of water).

Periods of missing record due to transducer or telemetry failures were minimal at all sites except $\mathrm{CH}-5$. Although the continuous water-level records were not filtered to remove the effects of atmospheric-pressure fluctuations, a general trend of declining water level is evident at each site during 1985. The total drop in water level ranged from about 0.5 foot in $\mathrm{CH}-5$ to 15 feet in PLV-2. These declines are thought to be related to the reduction in precipitation and ground-water recharge since the above-normal precipitation experienced during the winter of 1982-83. These well hydrographs show no evidence of deformation caused by seismic events or magmatic intrusion during 1985. 
The relatively rapid decline in water level of about 0.25 foot at $\mathrm{CH}-10 \mathrm{~B}$ in late December may have been caused by fluid production from well CW-2 during a two-week flow test that began December 13 (WESTEC, 1986). Fluid production averaged $1,200 \mathrm{gal} / \mathrm{min}$ during the test, and approximately 95 percent of the fluid was injected in well $\mathrm{CW}-1$. Although the water-level decline continued until about January 12, 1986, no subsequent rise in water level was observed.
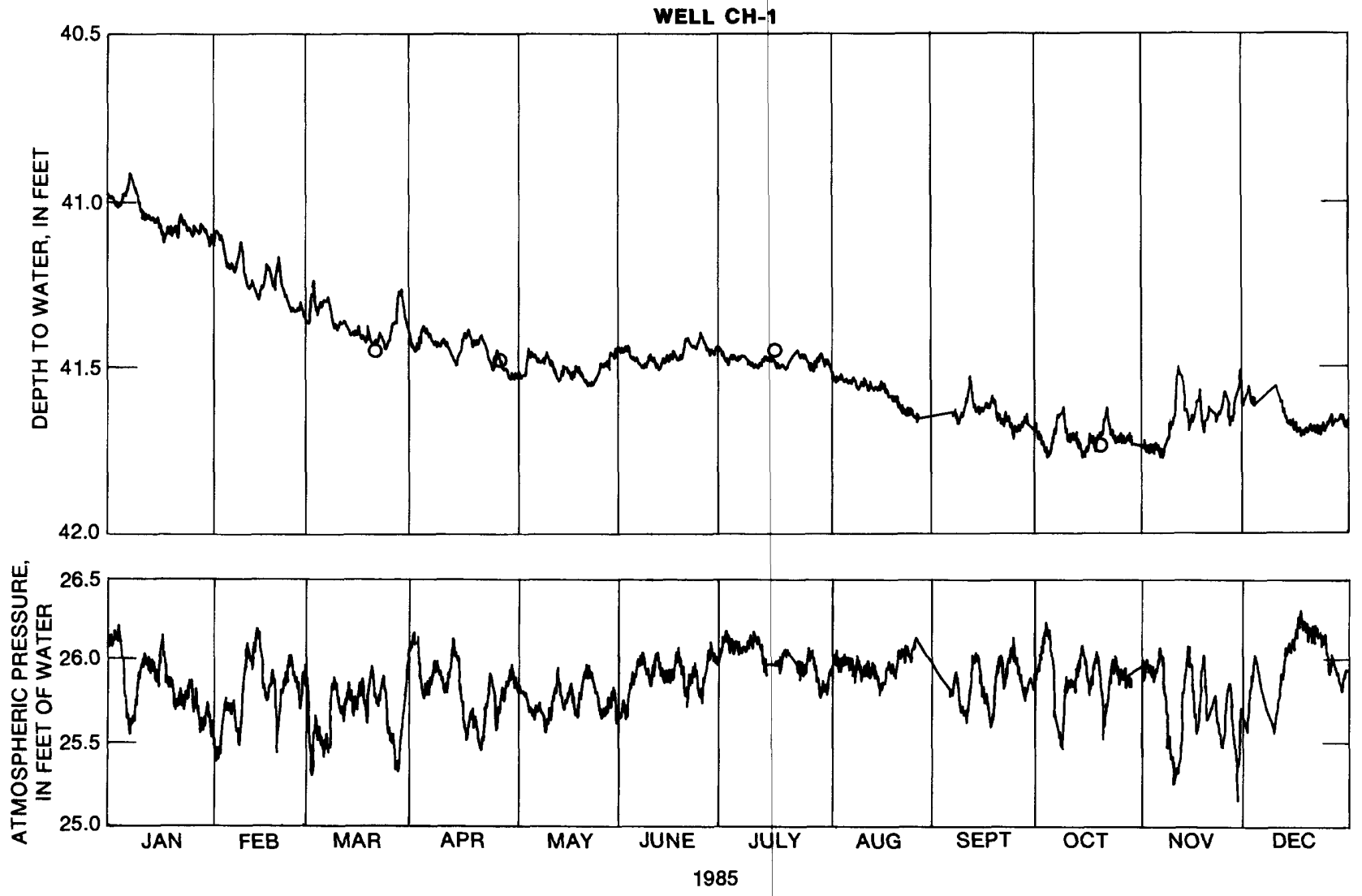

EXPLANATION

○ WATER-LEVEL MEASUREMENT

FIGURE 16. - Continuous records of depth to water and atmospheric pressure for well CH-1 during 1985. 

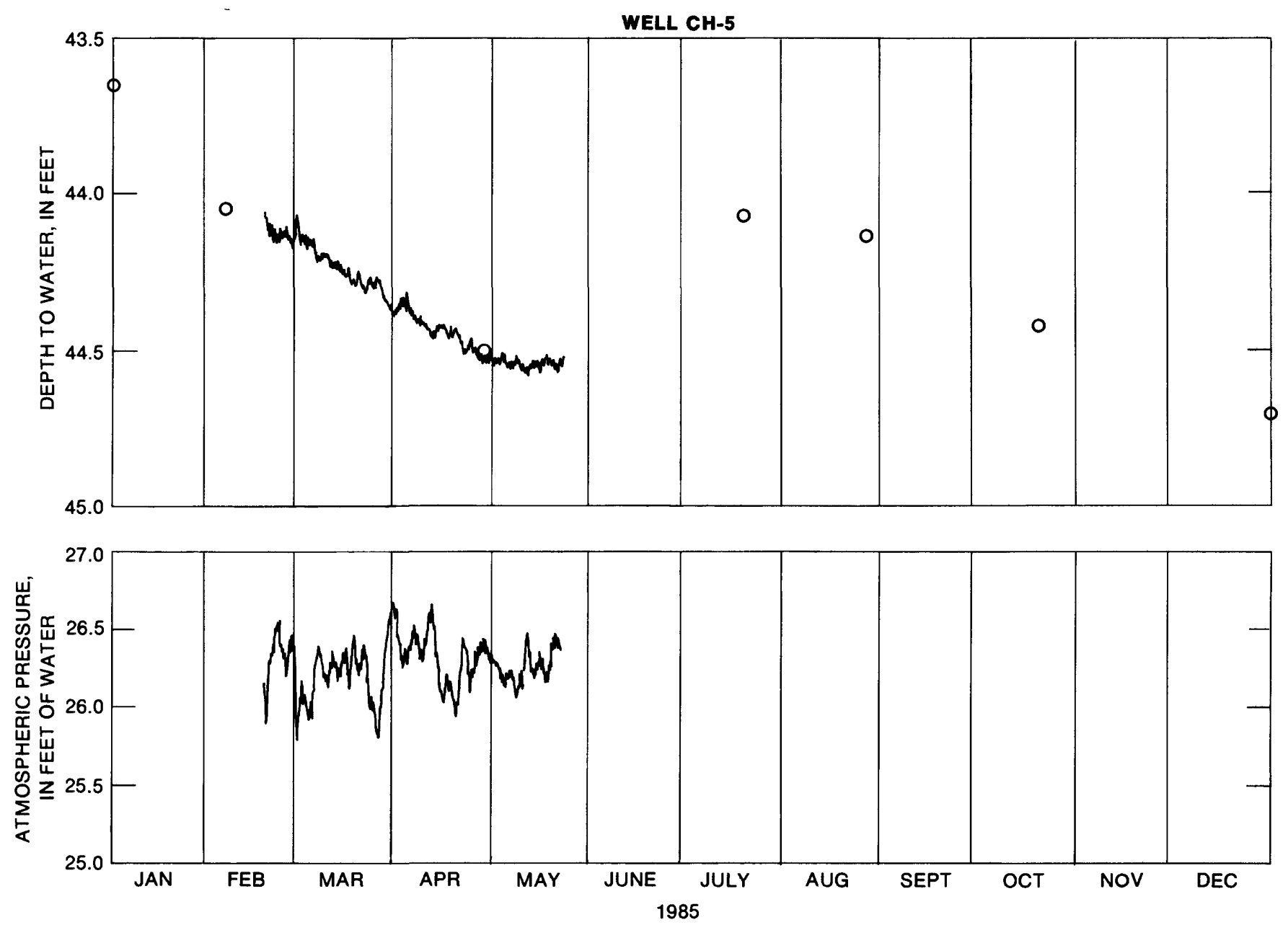

EXPLANATION

○ WATER-LEVEL MEASUREMENT

FIGURE 17. - Continuous records of depth to water and atmospheric pressure for well $\mathrm{CH}-5$ during February-May 1985. 
WELL CH-10B
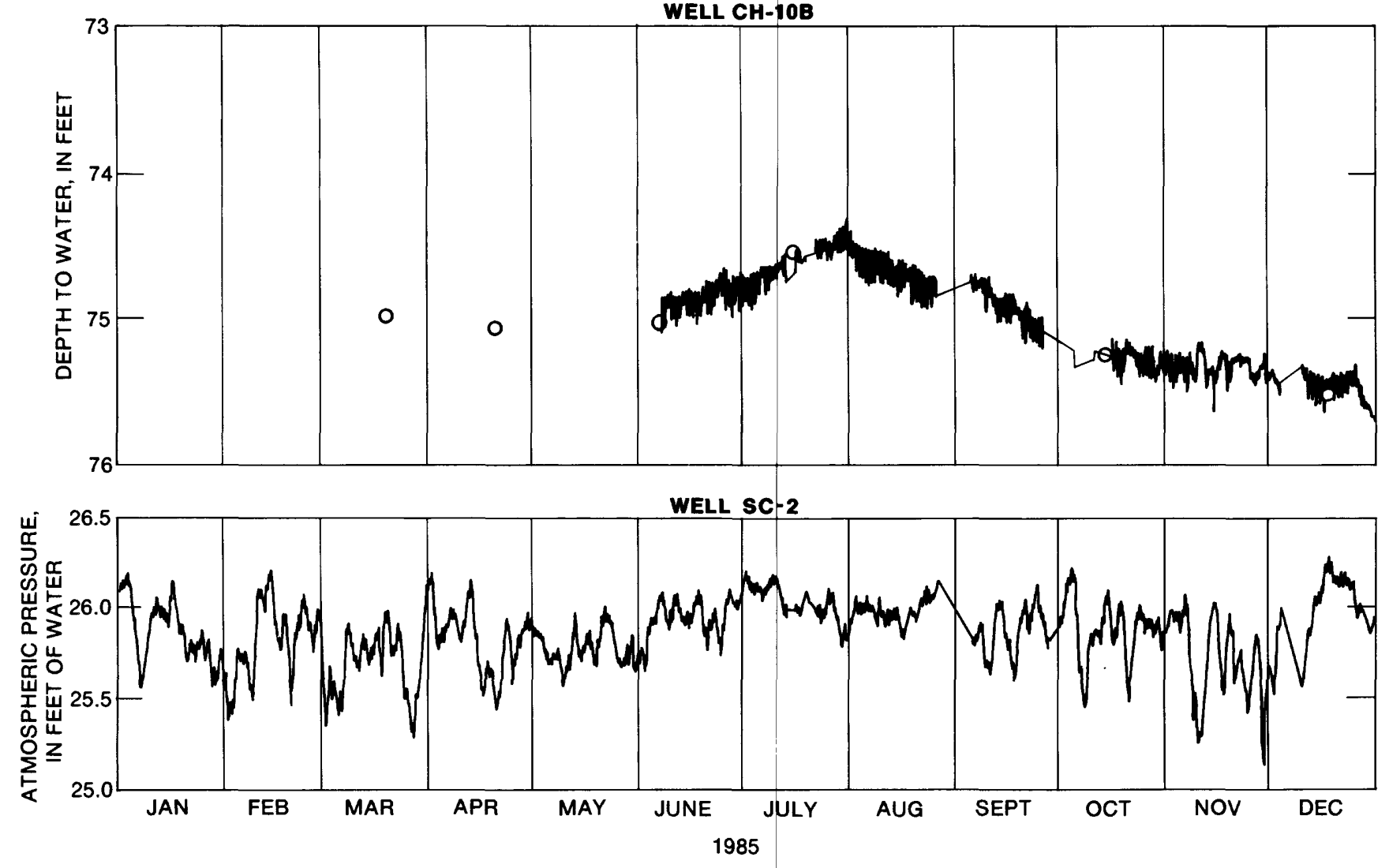

EXPLANATION

O WATER-LEVEL MEASUREMENT

Linear interpolations were made for periods of missing records

FIGURE 18. - Continuous records of depth to water for well $\mathrm{CH}-10 \mathrm{~B}$ and atmospheric pressure for well SC-2 during 1985. 

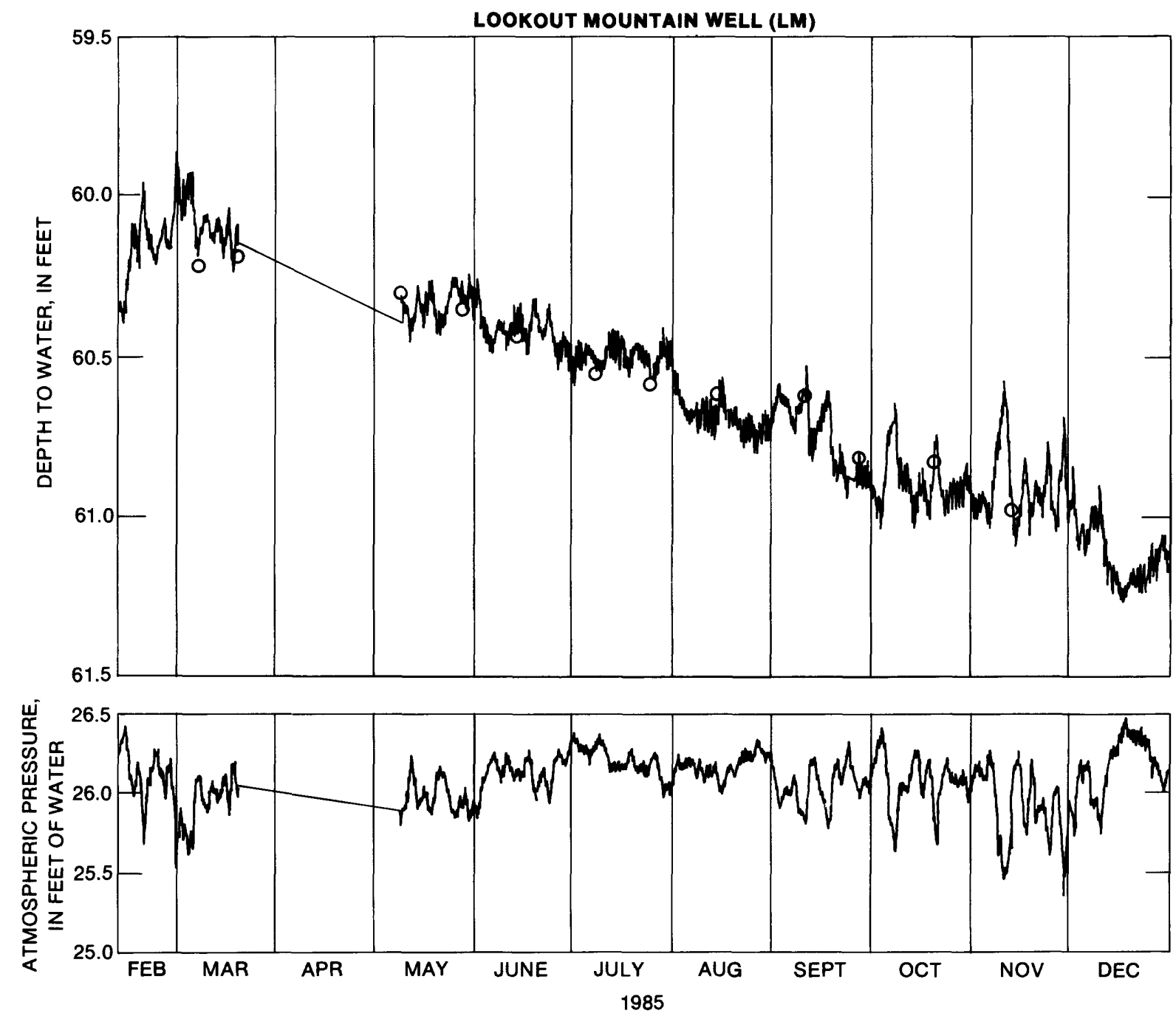

EXPLANATION

O WATER-LEVEL MEASUREMENT

Linear interpolations were made for periods of missing records

FIGURE 19. - Continuous records of depth to water and atmospheric pressure for well LM during 1985. 

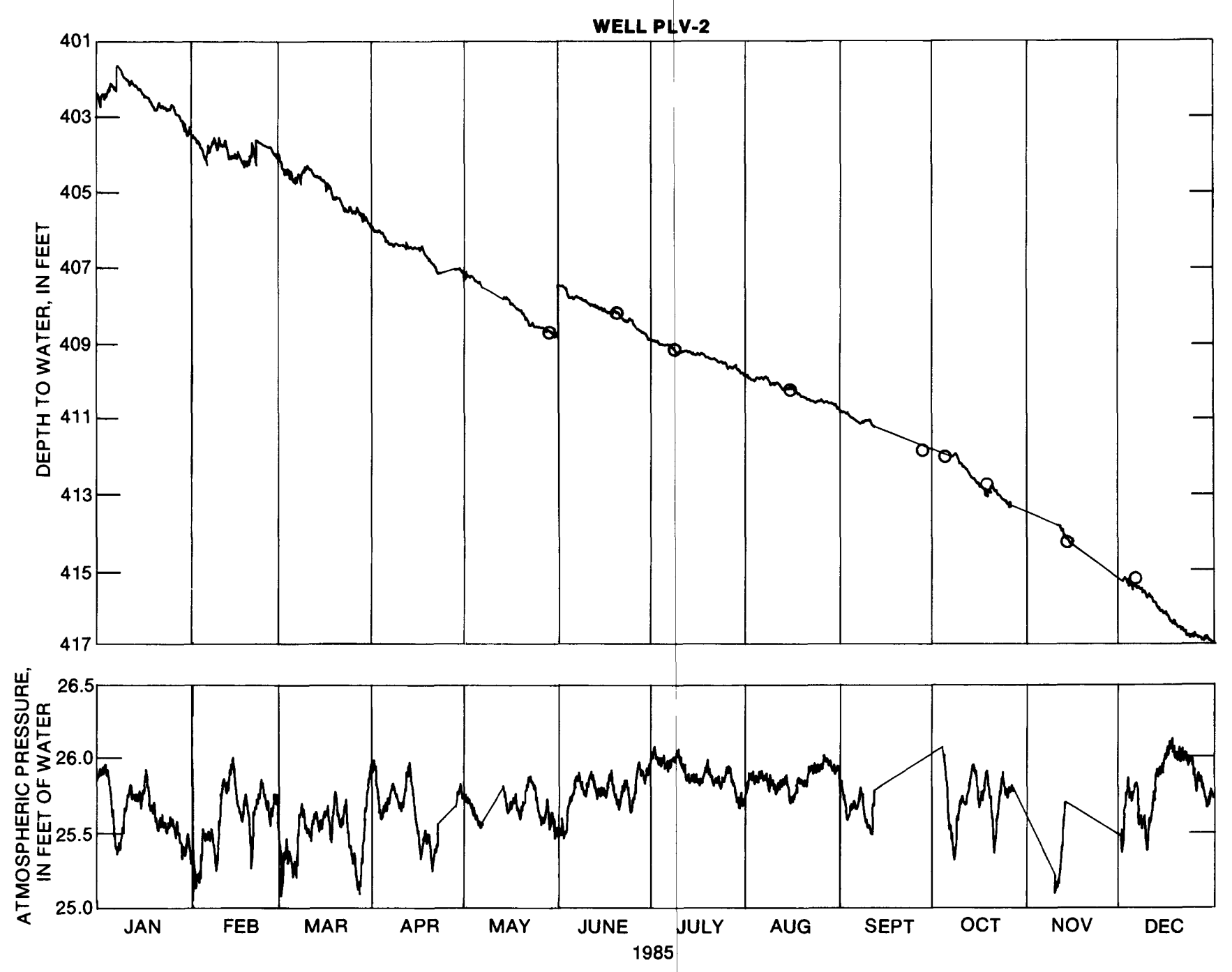

EXPLANATION

O WATER-LEVEL MEASUREMENT

Linear interpolations were made for periods of missing records

FIGURE 20. - Continuous records of depth to water and atmospheric pressure for well PLV-2 during 1985. 

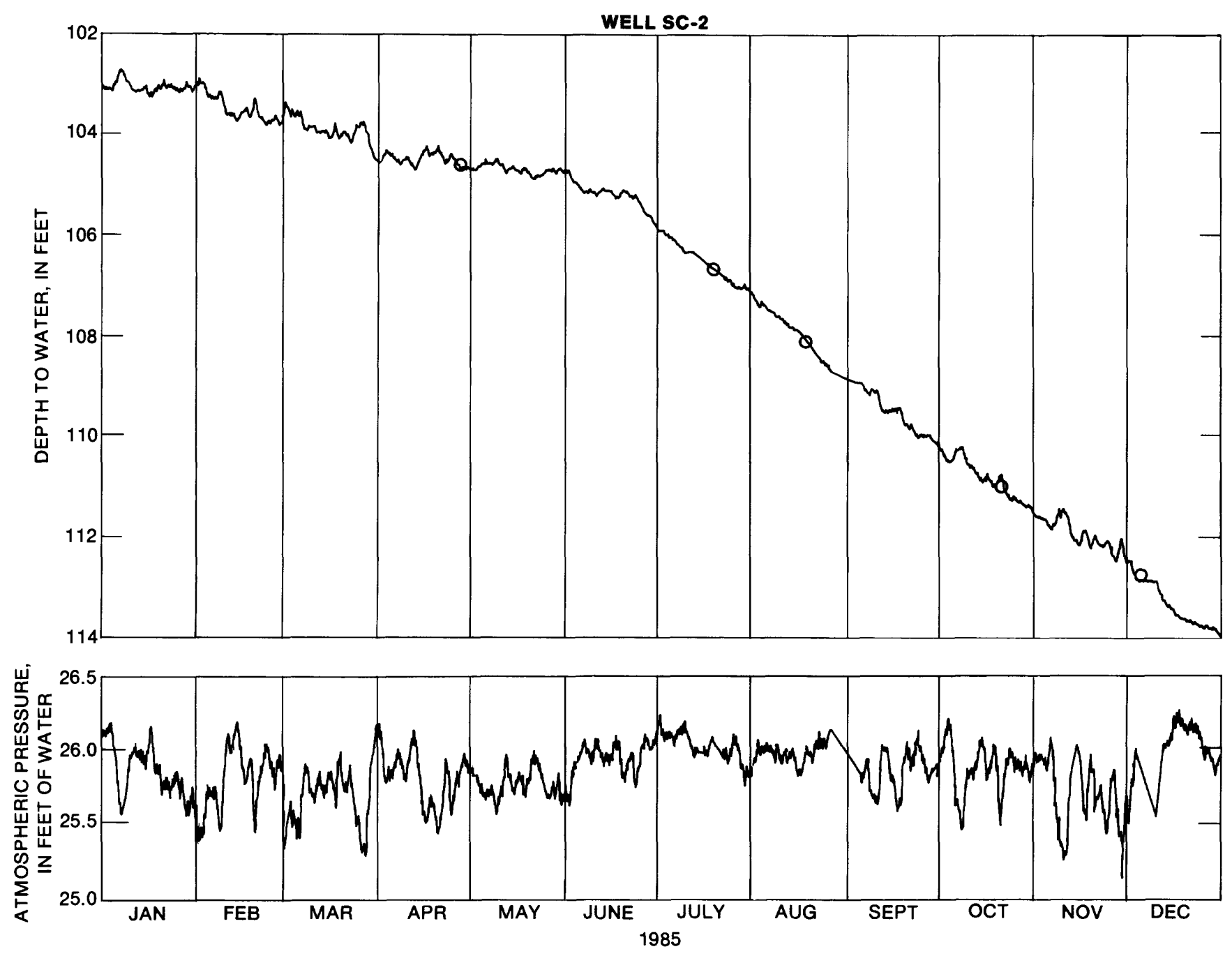

EXPLANATION

O WATER-LEVEL MEASUREMENT Linear interpolations were made for periods
of missing records

FIGURE 21. - Continuous records of depth to water and atmospheric pressure for well SC-2 during 1985. 
Temperature measurements during 1985 were made on a continuous basis at four thermal-discharge areas, and temperature profiles were recorded on one or more occasions in 14 wells. In this section, the 1985 temperature profiles are compared with profiles recorded in 1984, and continuous temperature measurements are plotted and described.

\section{Continuous Temperature Measurements}

A platinum resistance detector (RTD) was installed in a steam vent referred to as Basalt Fumarole (BF) (fig. 2; sec. 31, T. 3 S., R. 28 E.) on October 16, 1985, to measure gas temperature. Near-surface gas temperatures ranging from $71{ }^{\circ} \mathrm{C}$ to $85{ }^{\circ} \mathrm{C}$ have been measured on several occasions since 1983 at this site of weak steam discharge near the western margin of the resurgent dome. The RTD was set several inches into the bottom of a two-foot-deep sand-filled cavity and connected to a data logger set to sample temperatures at 10-minute intervals and to record the average temperature each hour.

The recorded temperature data are plotted in figure 22--along with atmospheric pressures recorded at well SC-2, 1.5 miles south of Basalt Fumarole. Variations in steam-vent temperature are seen to be strongly correlated with variations in atmospheric pressure. It is an inverse correlation, and thus steam-vent temperatures decrease as atmospheric pressures increase. The correlation applies to diurnal as well as longer term variations. A possible explanation for this correlation is that changes in atmospheric pressure cause changes in the rate of steam discharge, which in turn affects the surficial temperature in the steam vent.

If vent temperature is related to the quantity of vapor discharge from the steam vent, then this may be a useful site for detecting future changes in steam discharge that may result from crustal processes. Additional handheld temperature measurements made at Basalt Fumarole on six occasions since June 1983 are listed below.

\begin{tabular}{ccccc}
\hline Date & $\begin{array}{c}\text { Vent } \\
\text { temperature } \\
\text { (deg. Celsius) }\end{array}$ & Date & $\begin{array}{c}\text { Vent } \\
\text { temperature } \\
\text { (deg. Celsius) }\end{array}$ \\
\hline June 1, 1983 & 85 & 0ctober 9, 1984 & 75 \\
May 30, 1984 & 71 & July 7, 1985 & 81 \\
June 1, 1984 & 72 & 0ctober 16, 1985 & 76 \\
\hline
\end{tabular}

In contrast, changes in steam discharge at more vigorous vents at Casa Diablo are more difficult to detect from temperature measurements because the vent temperature is controlled mainly by the boiling point of water at local elevations $\left(93^{\circ} \mathrm{C}\right)$. 

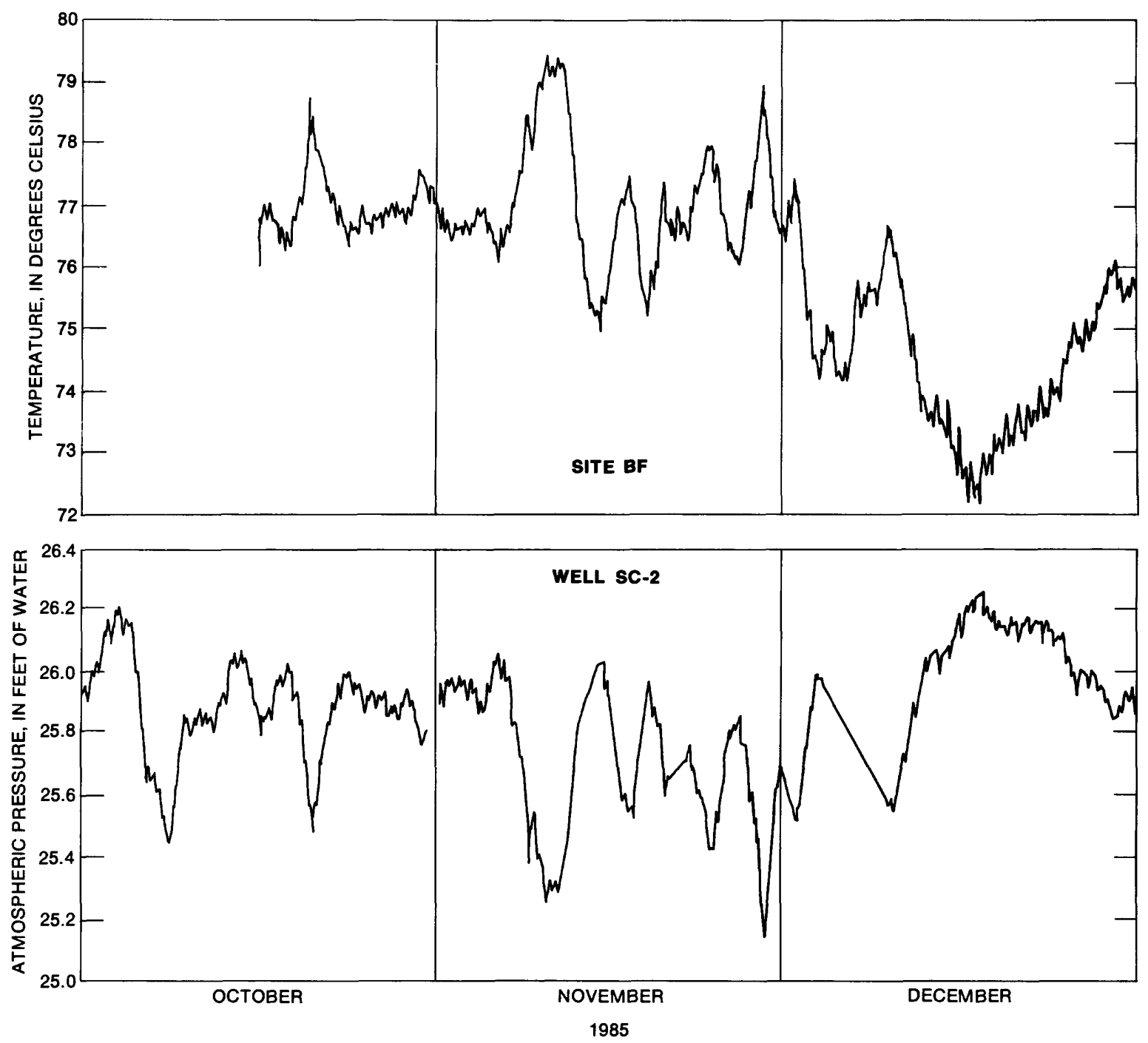

FIGURE 22. - Steam-vent temperature at site BF and atmospheric pressure at well SC-2, October-December 1985. 
Areas of abnormally high soil temperatures have been noted in the Long Valley caldera. Some of these areas, such as at Casa Diablo and near Hot Bubbling Pool, are associated with thermal springs or fumaroles. At other areas the only indications of high soil temperatures are stands of dead conifers or other vegetation and bare patches of ground following light snowfalls.

The soil temperature was recorded at one site that has no surface discharge of thermal water. The site is in the central part of Long Valley caldera in sec. 28, T. $3 \mathrm{~S} .$, R. $28 \mathrm{E}$. This site is on the resurgent dome along the west side of Long Canyon (LCF in fig. 2). Northwest-trending faults transect the area and may provide paths for convective transport of heat toward the land surface. The abnormal heat flow is evidenced by a large number of dead conifers and ground that is noticeably warm to the touch.

The soil temperature was recorded between January 1 and October 19, 1985, using a mercury-actuated mechanical recorder with a sensor placed approximately 3 feet below land surface. Mean daily temperatures (fig. 23) ranged from $78{ }^{\circ} \mathrm{C}$ to $80^{\circ} \mathrm{C}$ for the period.

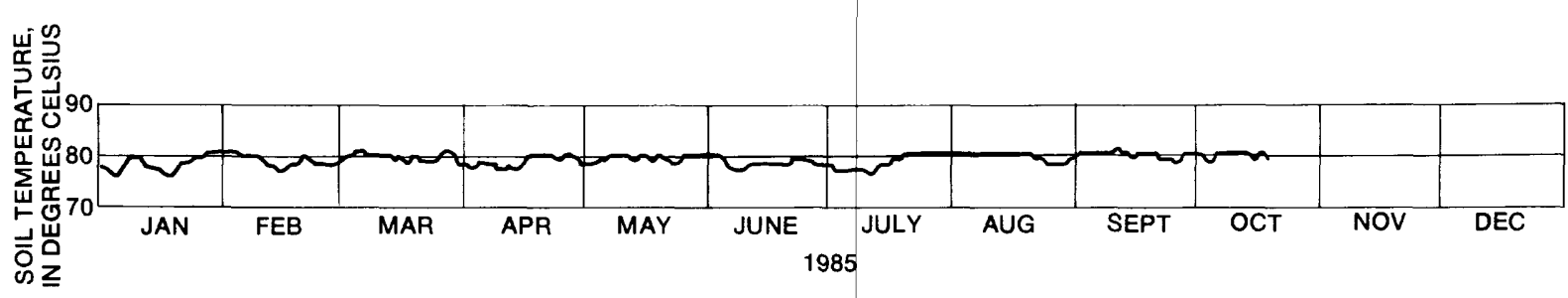

FIGURE 23. - Soil temperature at site LCF on the west side of Long Canyon, January-0ctober 1985.

\section{Temperature Profiles}

Temperature measurements in wells during 1985 were obtained for the most part from discrete-point resistance readings on a glass-bead thermistor. The same equipment was used to make temperature logs in 1984, except that logs for wells PLV-1 and PLV-2 were made by Tom Moses, U.S. Geological Survey, Menlo Park, California, using a continuously recording system with a glass-bead thermistor. Resistance values were converted to temperatures using calibration data obtained under laboratory conditions by R. J. Munroe, U.S. Geological Survey, Menlo Park, California. Profiles also were measured in 1985 in some wells using a continuous recording system with platinum-wire thermistors. Data from this system were furnished by Tom Urban, U.S. Geological Survey, Denver, Colorado. In all but two cases, the temperature profiles plotted in this report are representative of subsurface conditions undisturbed by the effects of well drilling, production, or injection. The profile in well CM-2 was disturbed November 1, 1984, by drilling and completion operations, and the profile in well CW-1 was disturbed Apri1 27, 
1985, by injection of relatively cool water during a 3-hour flow test earlier that day. Details of well construction and completion for the wells discussed in this section are given in table 15, and in Farrar and others (1985).

Temperature profiles in wells $\mathrm{CH}-10, \mathrm{CH}-10 \mathrm{~A}$, and $\mathrm{CH}-10 \mathrm{~B}$ are shown in figure 24. These wells are approximately 0.4 mile southeast of the springs in Hot Creek gorge. Differences between the 1984 and 1985 profiles at depths below the water level in each well are minor for $\mathrm{CH}-10 \mathrm{~B}$ but range from 0 to $15{ }^{\circ} \mathrm{C}$ for wells $\mathrm{CH}-10$ and $\mathrm{CH}-10 \mathrm{~A}$. In each case the 1984 and 1985 data were obtained with different logging equipment. The similarity of the 1984 and 1985 profiles in well $\mathrm{CH}-10 \mathrm{~B}$ indicates that the two temperature-measuring devices used at different times provide compatible data for detecting temperature changes over time. The reasons for the differences in the 1984 and 1985 profiles for $\mathrm{CH}-10$ and $\mathrm{CH}-10 \mathrm{~A}$ are unknown. Differences of similar magnitude between profiles on different dates prior to 1985 in these wells were also reported by Farrar and others (1985).

Temperature profiles are plotted in figures 25-28 for wells CM-2, CW-1, MW-1, MW-2, MW-3, MW-4, and MW-5, near Hot Bubbling Pool, and wells FP-1, PLV-1, PLV-2, and SC-2 (fig. 2). Well CW-1 is the so-called 01d Chance Well drilled in 1961 and used in 1985 for injection of water produced during two flow tests conducted on well $\mathrm{CW}-2$. Exploration wells $\mathrm{CW}-2$ and $\mathrm{CW}-3$ and the MW series of monitor wells were drilled for the Mammoth/Chance Geothermal Project in 1985. Well CM-2 was drilled by the U.S. Geological Survey for borehole seismic and pressure measurement but was never used for that purpose because of the high temperatures encountered.

As seen in figure 27, differences between the general thermal regimes at each of these sites are large. Conductive-temperature gradients are observed in all but well CW-1, and measured gradients range from $390{ }^{\circ} \mathrm{C} / \mathrm{km}$ in wells $\mathrm{MW}-4$ and MW-5 to $2,500{ }^{\circ} \mathrm{C} / \mathrm{km}$ in well $\mathrm{CM}-2$. Such large gradients suggest the presence of thermal aquifers not far below the bottoms of these wells, as evidenced in the temperature profile in well $\mathrm{CW}-1$ below a depth of about 200 feet. Temperature data for wells $\mathrm{CW}-2$ and $\mathrm{CW}-3$ are still proprietary.

Data on temperature changes with time are available only for wells CM-2 and CW-1 (fig. 25). As noted above, differences between the 1984 and 1985 profiles in well CM-2 are probably due mainly to the effects of drilling disturbances on the 1984 profile. For well CW-1 the cooling noted by Farrar and others (1985) below a depth of 230 feet between 1976 and 1983 continued into 1985. This effect was attributed to inflow of water at depths between 500 and 600 feet. The existence of a permeable formation within this interval is evidenced by the temperature minimum in the $\log$ of April 27, 1985, which appears to result from the loss of cooler injection water into this zone during the flow test noted above.

Differences between temperature profiles in 1984 and 1985 in wells PLV-1, PLV-2, and SC-2 (figs. 27-28) appear insignificant below the water level in each we11, except for the high-temperature-gradient zone below 1,800 feet in we11 PLV-1. The main reason for the differences seen in figure 27 are errors introduced in the process of digitizing the original graphical result furnished by Tom Moses, U.S. Geological Survey, Menlo Park, California. 

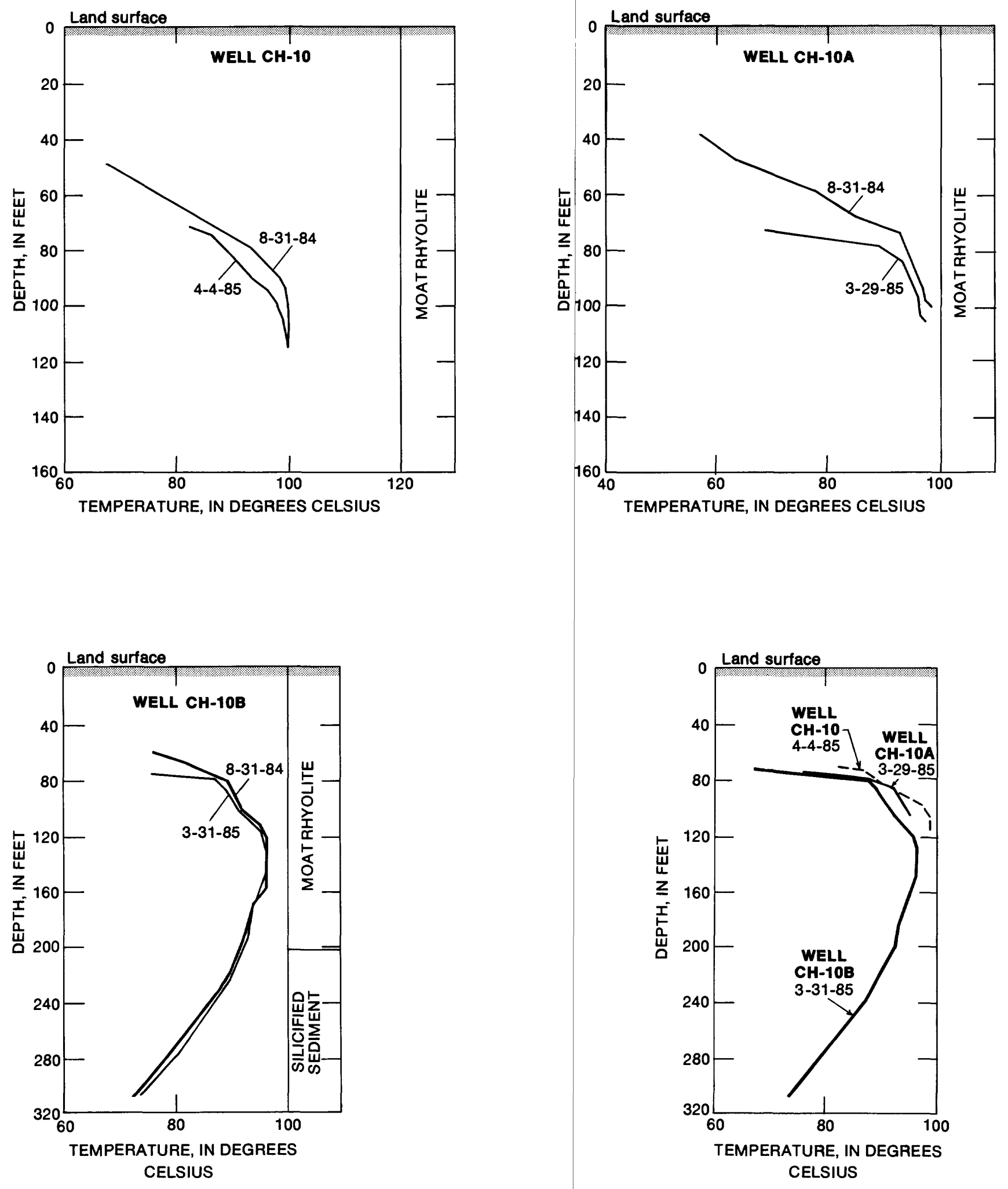

FIGURE 24. - Temperature profiles and lithology for wells $\mathrm{CH}-10, \mathrm{CH}-10 \mathrm{~A}$, and $\mathrm{CH}-10 \mathrm{~B}$. 

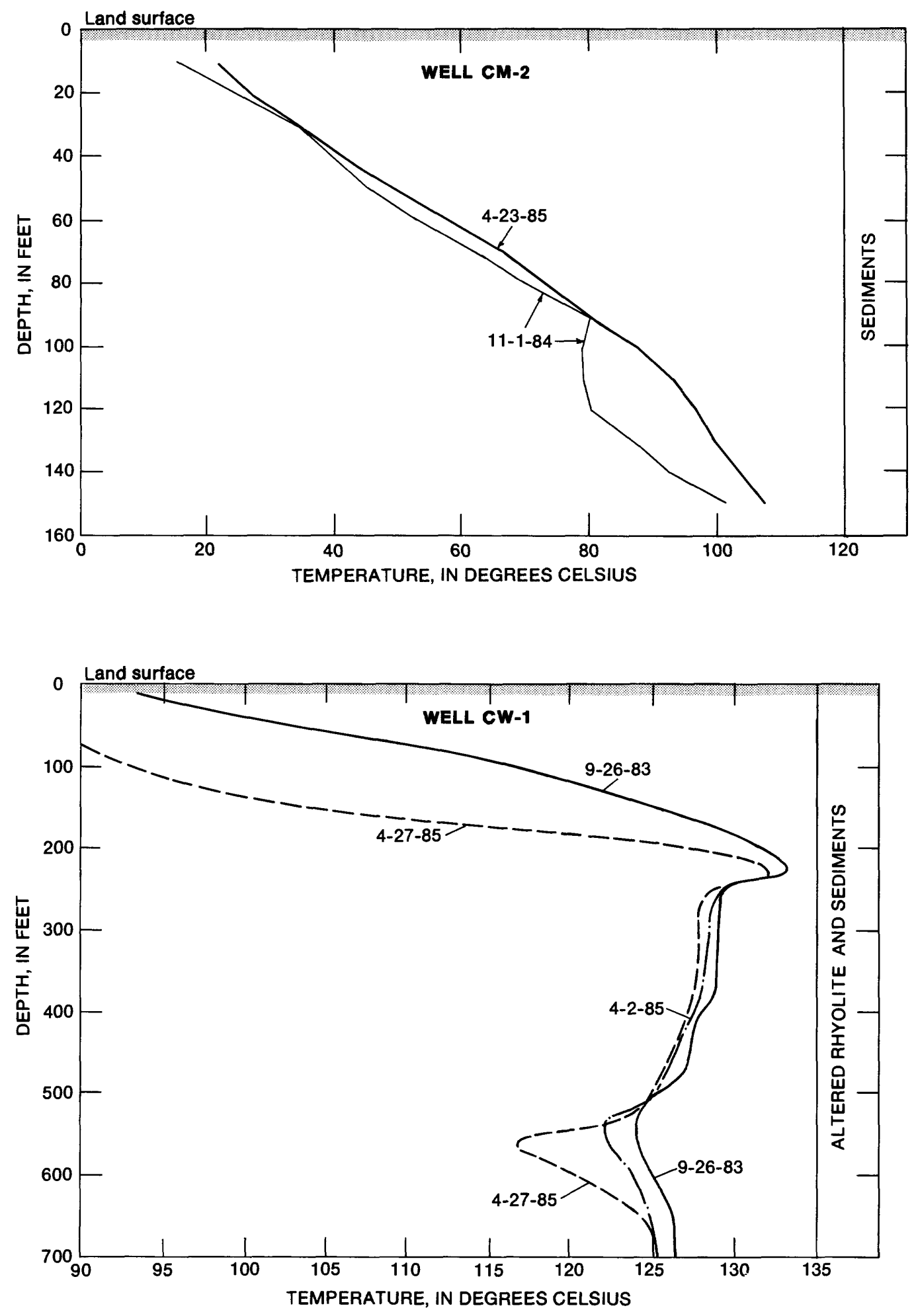

FIGURE 25. - Temperature profiles and lithology for wells CM-2 and CW-1. 

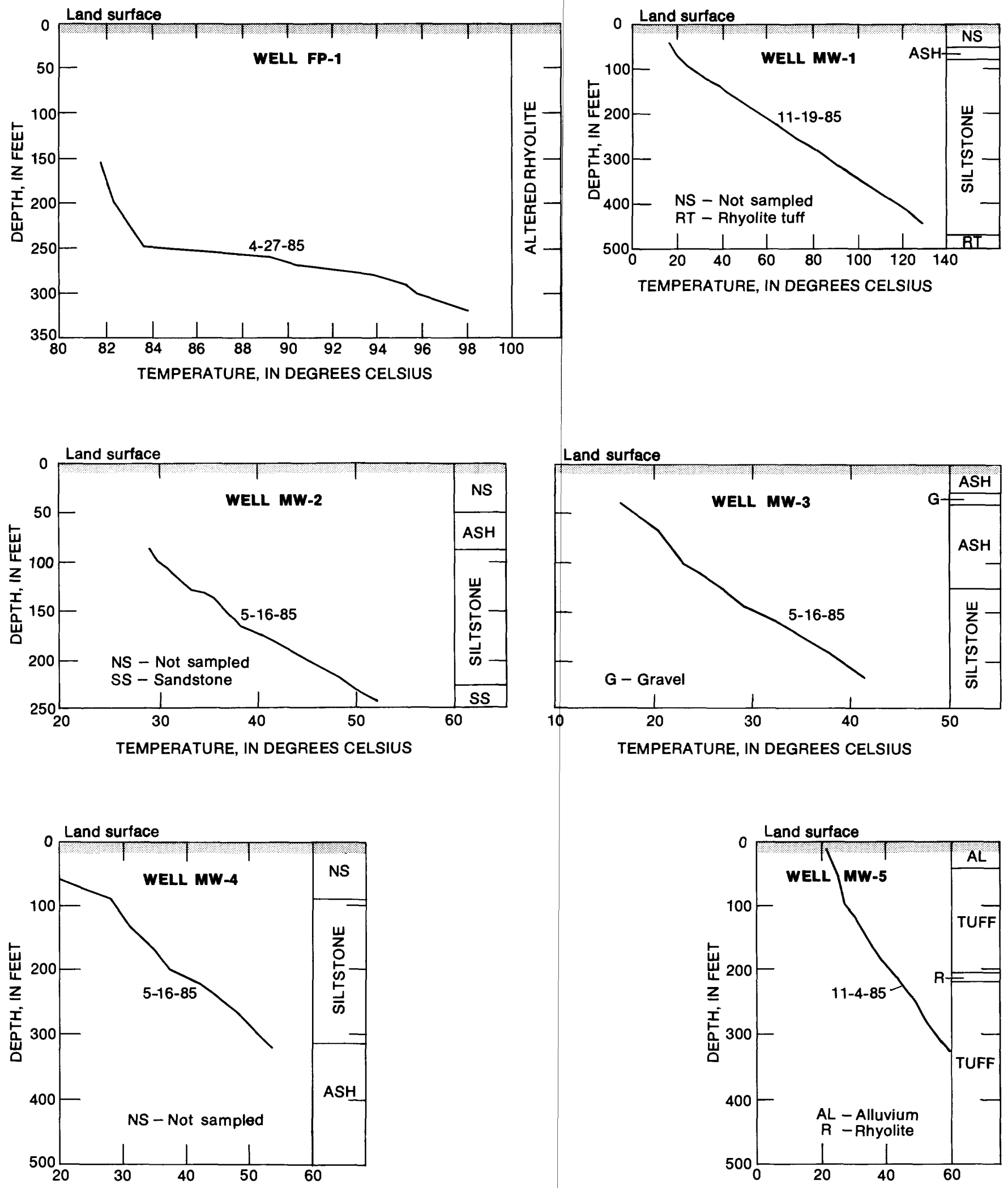

TEMPERATURE, IN DEGREES CELSIUS

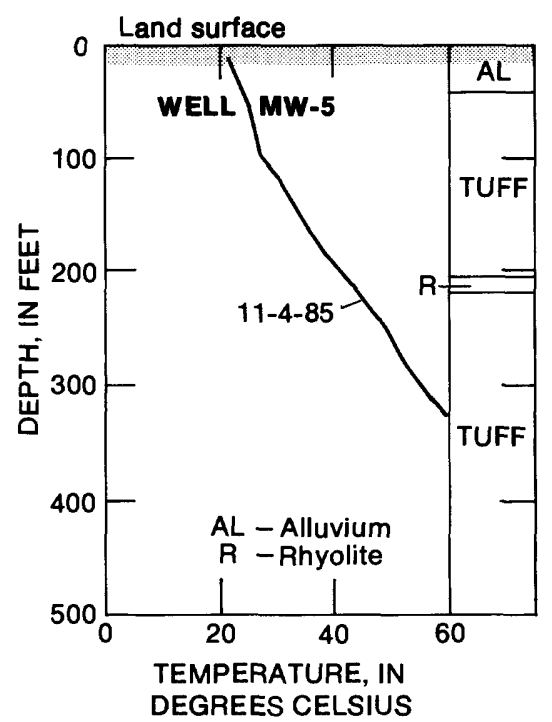

FIGURE 26. - Temperature profiles and lithology for wells FP-1, MW-1, MW-2, MW-3, MW-4, and MW-5. 

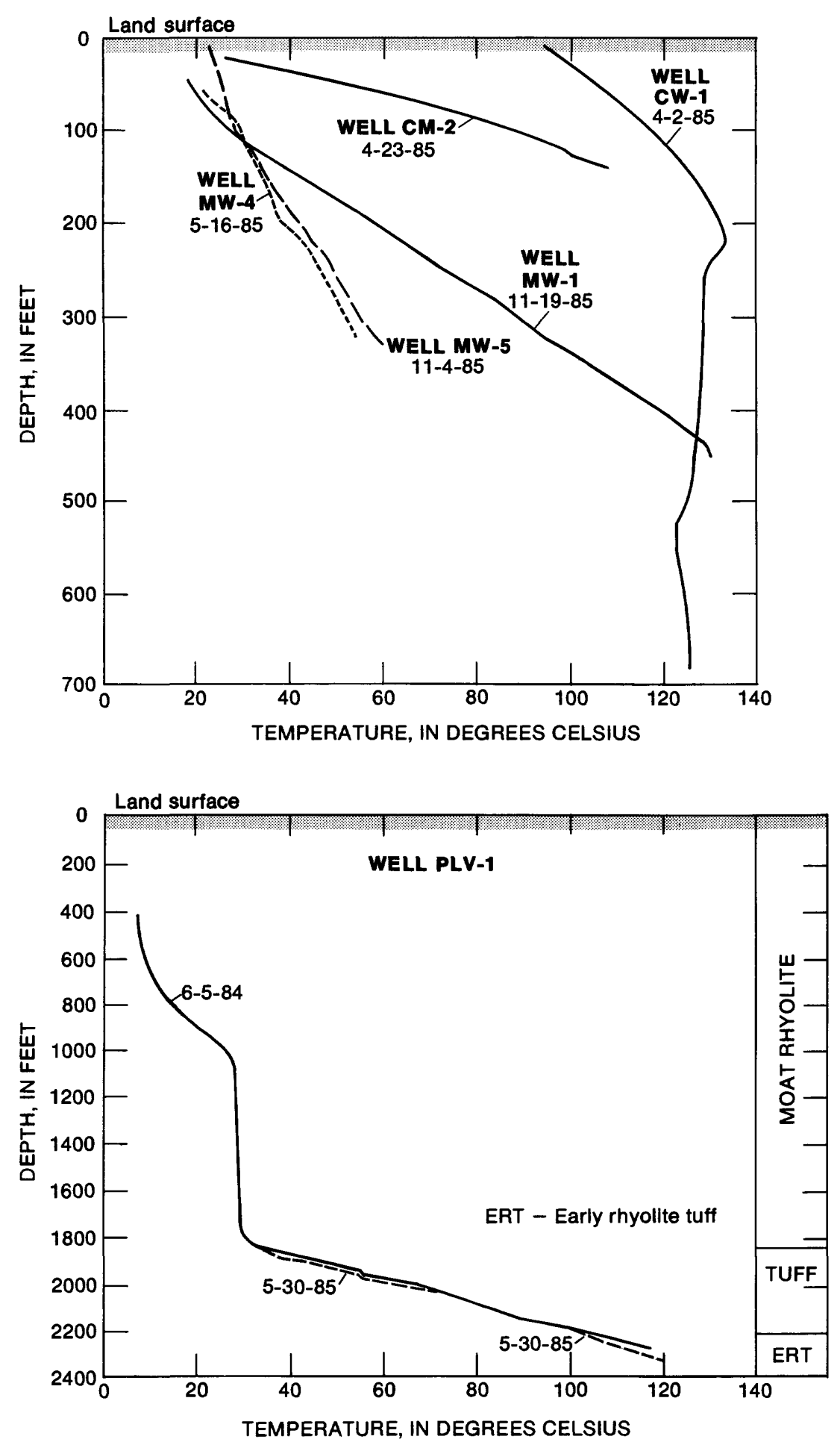

FIGURE 27. - Temperature profiles and lithology for well PLV-1, and comparison of most recent temperature profiles for wells CM-2, CW-1, MW-1, MW-4, and MW-5. 

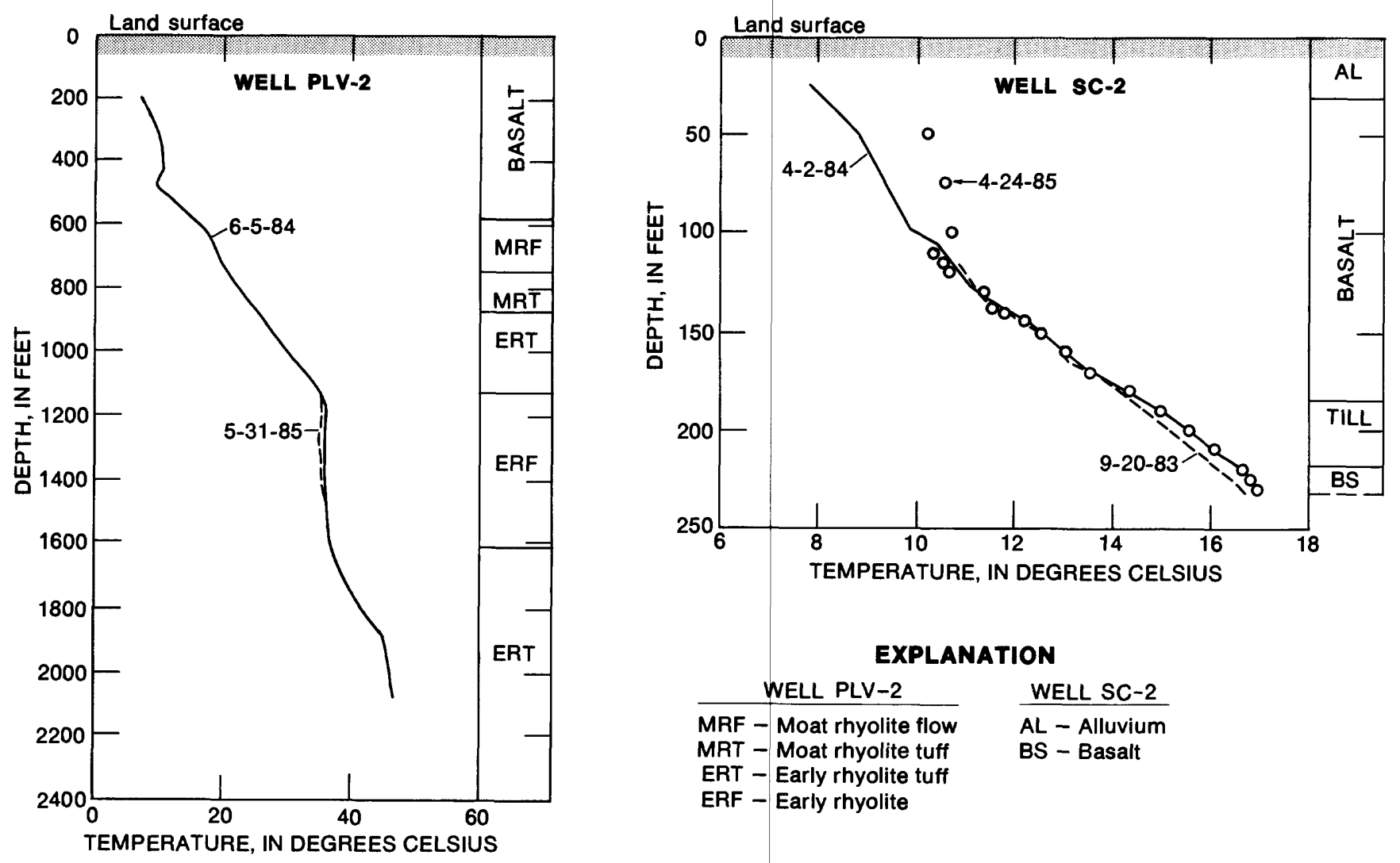

FIGURE 28. - Temperature profiles and lithology for wells PLV-2 and SC-2.

\section{REFERENCES CITED}

Bailey, R.A., Dalrymple, G.B., and Lanphere, M.A., 1976, Volcanism, structure, and geochronology of Long Valley caldera, Mono County, California: Journal of Geophysical Research, v. 81, no. 5, p. 725-744.

Bailey, R.A., and Koeppen, R.P., 1977, Preliminary geologic map of Long Valley caldera: U.S. Geological Survey Open-File Report 77-468.

Bezore, S.P. and Sherburne, R.W., 1985, Monitoring geothermal wells and spring conditions in selected areas of California for earthquake precursors: California Department of Conservation, Division of Mines and Geology, Final Technical Report Open-File Report 85-12, 56 p.

Brown, E., Skougstad, M.W., and Fishman, M.J., 1970, Methods for collection and analysis of water samples for dissolved minerals and gases: U.S. Geological Survey Techniques in Water-Resources Investigations, Book 5, Chapter Al, $160 \mathrm{p}$. 
California Department of Water Resources, 1967, Investigation of geothermal waters in the Long Valley area, Mono County, $141 \mathrm{p}$.

1973, Mammoth basin resources environmental study (Final Report), $70 \mathrm{p}$.

Claassen H.C., 1982, Guidelines and techniques for obtaining water samples that accurately represent the water chemistry of an aquifer: U.S. Geological Survey Open-File Report 81-1024, 40 p.

Craig, H., 1961, Standard for reporting concentrations of deuterium and oxygen-18 in natural waters: Science, v. 133, p. 1833.

Farrar, C.D., Sorey, M.L., Rojstaczer, S.A., Janik, C.J., Mariner, R.H., Winnett, T.L., and Clark, M.D., 1985, Hydrologic and geochemical monitoring in Long Valley caldera, Mono County, California, 1982-84: U.S. Geological Survey Water-Resources Investrgations Report 85-4183, $127 \mathrm{p}$.

Faure, G., 1977, Principles of Isotope Geology: John Wiley and Sons, New York, $464 \mathrm{p}$.

Fournier, R.0., and Rowe, J.J., 1966, Estimation of underground temperatures from the silica content of water from hot springs and wet-steam wells: American Journal of Science, v. 264, p. 685-672.

Fournier, R.0., Sorey, M.L., Mariner, R.H., and Truesde11, A.H., 1979, Chemical and isotopic prediction of aquifer temperatures in the geothermal system at Long Valley, California: Journal of Volcanology and Geothermal Research, v. 5, p. 17-34.

Fournier, R.0., and Truesdell, A.H., 1973, An empricial Na-K-Ca chemical geothermometer for natural waters: Geochemica et Cosmochimica Acta, v. 37, p. $1255-1275$.

Kharaka, Y.K., and Barnes, Ivan, 1973, SOLMNEQ: Solution-mineral equilibrium computations: U.S. Department of Commerce, Springfield, Virginia, NTIS Report PB 215-89y, 81 p.

Lewis, R.E., 1974, Data on wells, springs, and thermal springs in Long Valley, Mono County, California: U.S. Geological Survey Open-File Report, $52 \mathrm{p}$.

Lico, M.S., Kharaka, Y.K., Carothers, W.W., and Wright, V.A., 1982, Methods for collection and analysis of geopressured geothermal and oil field waters: U.S. Geological Survey Water-Supply Paper 2194, 21 p.

Mariner, R.H., and Willey, L.M., 1976, Geochemistry of thermal waters in Long Valley, Mono County, California: Journal of Geophysical Research, v. 81 , no. 5, p. 792-800.

Miller, C.D., 1985, Holocene eruptions at the Inyo volcanic chain, California: Implications for possible eruptions in Long Valley caldera: Geology, v. 13, p. 14-17. 
Miller, C.D., Mullineaux, D.R., Crandell, D.R., and Bailey, R.A., 1982, Potential hazards from future volcanic eruptions in the Long Valley-Mono Lake Area, east-central California and southwest Nevada--A preliminary assessment: U.S. Geological Survey Circular 877,10 p.

Skougstad, M.W., Fishman, M.J., Friedman, L.C. Erdmann, D.E., and Duncan, S.S., eds., 1979, Methods for determination of inorganic substances in water and fluvial sediments: U.S. Geological Survey, Techniques of Water-Resources Investigations, Book 5, Chapter A1, $626 \mathrm{p}$.

Sorey, M.L. and Clark, M.D., 1981, Changes in the discharge characteristics of thermal springs and fumaroles in the Long Valley caldera, Mono County, California, resulting for earthquakes on May 25-27, 1980: U.S. Geological Survey Open-File Report 81-203, 22 p.

Sorey, M.L., Farrar, C.D., and Wollenberg, H.A., eds., 1984, Proceedings of the workshop on hydrologic and geochemical monitoring in the Long Valley caldera: Lawrence Berkeley Laboratory Report LBL 20020, 82 p.

Sorey, M.L. and Lewis, R.E., 1976, Convective heat flow from hot springs in the Long Valley caldera, Mono County, California: Journal of Geophysical Research, v. 81, no. 5, p. 785-791.

Sorey, M.L., Lewis, R.E., and 01msted, F.H., 1978, The hydrothermal system of Long Valley caldera, California: U.S. Geological Survey Professional Paper 1044-A, 60 p.

Thompson, J.M., 1975, Selecting and collecting thermal springs for chemical analysis: A method for field personnel, U.S. Geological Survey Open-File Report 75-68, $11 \mathrm{p}$.

U.S. Forest Service, 1980-84, Water resources data for Mammoth Ranger District, Inyo National Forest, California: Annual Reports.

WESTEC Services, Inc., 1986 Draft environmental impact report Mammoth/Chance geothermal project: Prepared for County of Mono, Office of Energy Management, Mammoth Lakes, California, Volume I, 260 p.

Willey, L.M., O'Neil, J.R., and Rapp, J.B., 1974, Chemistry of thermal waters in Long Valley, Mono County, California: U.S. Geological Survey Open-File Report, $19 \mathrm{p}$.

Wood, W.W., 1976, Guidelines for collection and field analysis of ground-water samples for selected unstable constituents: U.S. Geological Survey Techniques in Water-Resources Investigations, Book 1 , Chapter D2, $24 \mathrm{p}$. 
TABLES

- 
TABLE 1.---Chemical analyses of water

Feature: Name of sample site and designation (in parentheses) used in figures and tables throughout report.

Laboratory: $B A B C$ : Babcock and Sons, Riverside, CA; LBL: Lawrence Berkeley Laboratory (A. White); USGS-C: U.S. Geological Survey Central Laboratory, Arvada, C0; LANL: LoS Alamos National Laboratory (analyzed by P. Trujillo and D. Counce): USGS-M: U.S. Geological Survey, Menlo Park, CA (analyzed by $T$. Presser).

\begin{tabular}{|c|c|c|c|c|c|c|c|c|c|}
\hline $\begin{array}{c}\text { Feature } \\
\text { (designation) }\end{array}$ & $\begin{array}{l}\text { Collec- } \\
\text { tion } \\
\text { date }\end{array}$ & $\begin{array}{l}\text { Labor- } \\
\text { atory }\end{array}$ & $\begin{array}{l}\text { Temper- } \\
\text { a ture } \\
\left({ }^{\circ} \mathrm{C}\right)\end{array}$ & $\mathrm{pH}$ & $\mathrm{Ca}$ & $\mathrm{Mg}$ & $\mathrm{Na}$ & $K$ & $\begin{array}{l}\text { Alka- } \\
\text { linity }\end{array}$ \\
\hline
\end{tabular}

Alkali Lakes-Lake Crowley area - springs in secs. 21 and 36, T. 3 S., R. 29 E.

$\begin{array}{lllllllllll}\text { Unnamed spring, } & 05-25-85 & \text { LANL } & 57.6 & 6.8 & 25.0 & 0.65 & 382 & 31 & 635 L\end{array}$
sec. $21 \mathrm{Pl}$

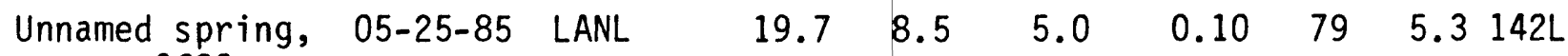
sec. 3602

Casa Diablo area - springs in secs. 15, 31, 32, and 33, T. 3 S., R. 28 E.

\begin{tabular}{|c|c|c|c|c|c|c|c|c|c|}
\hline $\begin{array}{l}\text { Colton Spring } \\
\text { (CS) }\end{array}$ & $\begin{array}{l}02-04-85 \\
05-26-85 \\
12-18-85\end{array}$ & $\begin{array}{l}\text { USGS-C } \\
\text { LANL } \\
\text { USGS-C }\end{array}$ & $\begin{array}{l}93.1 \\
93.8 \\
92.9\end{array}$ & $\begin{array}{l}8.3 \\
8.7 \\
8.5\end{array}$ & $\begin{array}{l}1.4 \\
2.0 \\
1.4\end{array}$ & $\begin{array}{r}<0.01 \\
0.05 \\
<0.01\end{array}$ & $\begin{array}{l}360 \\
408 \\
380\end{array}$ & $\begin{array}{l}26 \\
27 \\
27\end{array}$ & $\begin{array}{l}335 \\
365 L \\
393\end{array}$ \\
\hline $\begin{array}{l}\text { North Spring } \\
\text { (CDNS) }\end{array}$ & $\begin{array}{l}02-06-85 \\
07-16-85\end{array}$ & $\begin{array}{l}\text { USGS-C } \\
\text { USGS-C } \\
\text { LANL }\end{array}$ & $\begin{array}{l}86.1 \\
90.0 \\
90.0\end{array}$ & $\begin{array}{l}6.3 \\
6.7 \\
6.7\end{array}$ & $\begin{array}{l}11.0 \\
12.0 \\
11.2\end{array}$ & $\begin{array}{l}1.4 \\
1.5 \\
1.6\end{array}$ & $\begin{array}{l}230 \\
250 \\
241\end{array}$ & $\begin{array}{l}21 \\
23 \\
24\end{array}$ & $\begin{array}{l}43 \\
39 L \\
44 L\end{array}$ \\
\hline $\begin{array}{c}\text { Milky Pool } 3 \\
(M P-3)\end{array}$ & $\begin{array}{l}02-06-85 \\
07-16-85\end{array}$ & $\begin{array}{l}\text { USGS-C } \\
\text { USGS-C }\end{array}$ & $\begin{array}{l}77.7 \\
88.5\end{array}$ & $\begin{array}{l}7.0 \\
8.4\end{array}$ & $\begin{array}{l}1.7 \\
1.0\end{array}$ & $\begin{array}{r}0.01 \\
<0.01\end{array}$ & $\begin{array}{l}260 \\
330\end{array}$ & $\begin{array}{l}28 \\
26\end{array}$ & $\begin{array}{l}101 \\
175 \mathrm{~L}\end{array}$ \\
\hline Geyser (CDG) & $05-28-85$ & LANL & 92 & 9.1 & 2.2 & 0.06 & 458 & 44 & 395L \\
\hline $\begin{array}{l}\text { Meadow Spring } \\
\text { (MS) }\end{array}$ & $05-26-85$ & LANL & 62.5 & 6.2 & 4.2 & 0.65 & 241 & 36 & 106 \\
\hline
\end{tabular}

Casa Diablo area - wells in secs. 32 and 33, T. 3 S., R. 28 E.

\begin{tabular}{|c|c|c|c|c|c|c|c|c|c|}
\hline MBP-1 & $107-11-85$ & $\begin{array}{l}\text { USGS-C } \\
\text { LANL } \\
\text { LBL }\end{array}$ & $\begin{array}{l}168 \\
168 \\
168\end{array}$ & $\begin{array}{c}6.2 \\
6.2 \\
--\end{array}$ & $\begin{array}{l}3.9 \\
2.2 \\
1.8\end{array}$ & $\begin{array}{l}0.10 \\
0.15 \\
0.12\end{array}$ & $\begin{array}{l}360 \\
352 \\
348\end{array}$ & $\begin{array}{l}33 \\
38 \\
35\end{array}$ & $\begin{array}{l}355 \mathrm{~L} \\
348 \mathrm{~L} \\
360 \mathrm{~L}\end{array}$ \\
\hline MBP-3 & $107-12-85$ & $\begin{array}{l}\text { USGS-C } \\
\text { LANL } \\
\text { LBL }\end{array}$ & $\begin{array}{l}171 \\
171 \\
171\end{array}$ & $\begin{array}{l}6.1 \\
6.1 \\
--\end{array}$ & $\begin{array}{l}1.2 \\
1.2 \\
3.2\end{array}$ & $\begin{array}{l}0.10 \\
0.19 \\
0.12\end{array}$ & $\begin{array}{l}350 \\
344 \\
349\end{array}$ & $\begin{array}{l}36 \\
38 \\
35\end{array}$ & 36 \\
\hline
\end{tabular}

See footnotes at end of table. 
from selected springs and wells

Results are in milligrams per liter except iron $(\mathrm{Fe})$, mercury $(\mathrm{Hg})$, manganese $(\mathrm{Mg})$, and zinc $(\mathrm{Zn})$, which are in micrograms per liter, and $\mathrm{pH}$, which is in standard units. <, less than; --, no data.

Alkalinity: Calculated as the equivalent concentration of calcium carbonate;

field measurement except for laboratory measurements noted by "L".

Dissolved solids: Residue on evaporation at $180^{\circ} \mathrm{C}$, except calculated values indicated by "c".

\begin{tabular}{rrrrrrrrrrrrr}
\hline $\mathrm{SO}_{4}$ & $\mathrm{Cl}$ & $\mathrm{F}$ & $\mathrm{SiO}_{2}$ & $\begin{array}{c}\text { Dis- } \\
\text { solved } \\
\text { solids }\end{array}$ & As & $\mathrm{B}$ & $\mathrm{Li}$ & $\mathrm{Fe}$ & $\mathrm{Hg}$ & $\mathrm{Mn}$ & $\mathrm{Zn}$ \\
\hline & & & & & & & & & & & & \\
62 & 150 & 4.5 & 195 & 1,400 & 0.3 & 6.5 & 1.8 & 160 & $<50$ & 160 & $<10$ \\
17 & 21 & 1.7 & 73 & 309 & $<0.1$ & 0.6 & 0.2 & $<10$ & $<50$ & 10 & $<10$
\end{tabular}

$\begin{array}{rrrrrrrrrrrr}130 & 270 & 11.0 & 300 & 1,320 & 1.7 & 11.0 & 2.5 & <3 & 0.3 & 10 & <3 \\ 133 & 260 & 10.7 & 250 & 1,266 & 1.5 & 11.6 & 3.5 & <20 & <50 & 20 & <10 \\ 140 & 270 & 13.0 & 250 & 1,310 & 1.7 & 12.0 & 3.0 & <3 & 0.3 & 24 & <3 \\ 180 & 260 & 8.9 & 260 & 1,020 & 1.9 & 11.0 & 1.0 & 37 & 0.2 & 49 & 11 \\ 170 & 270 & 10.0 & 230 & 1,010 & 1.5 & 11.0 & 1.2 & 45 & 1.2 & 42 & 4 \\ 170 & 254 & 8.4 & 227 & 974 \mathrm{c} & 1.8 & 11.8 & 1.3 & 40 & <100 & 50 & <10 \\ 150 & 260 & 12.0 & 220 & 1,030 & 1.9 & 11.0 & 1.0 & 33 & 0.2 & 24 & 11 \\ 140 & 290 & 13.0 & 230 & 1,160 & 2.2 & 12.0 & 1.9 & 12 & 0.9 & 1 & <3 \\ 137 & 298 & 13.7 & 300 & 1,326 & 1.9 & 13.5 & 3.8 & 130 & <50 & <20 & <10 \\ 122 & 212 & 7.9 & 189 & 768 & 2.1 & 9.3 & 1.6 & <20 & <50 & <20 & <10\end{array}$

$\begin{array}{rrrrlrlllrrr}110 & 260 & 11.0 & 250 & 1,270 & 1.0 & 11.0 & 2.7 & 39 & 2.6 & 8 & 11 \\ 107 & 245 & 11.0 & 257 & 1,240 \mathrm{c} & 1.1 & 11.0 & 3.1 & 30 & <100 & <10 & <10 \\ 50 & 262 & 10.4 & 362 & 1,251 \mathrm{c} & -- & 10.8 & 2.5 & 111 & -- & -- & -- \\ 120 & 270 & 11.0 & 250 & 1,250 & 1.1 & 11.0 & 2.6 & 35 & 2.3 & 5 & 8 \\ 106 & 237 & 10.2 & 259 & 1,212 \mathrm{c} & 0.8 & 10.7 & 3.1 & 80 & <100 & <10 & <10 \\ 64 & 253 & 10.3 & 315 & 1,205 \mathrm{c} & -- & 10.4 & 2.5 & 21 & -- & -- & --\end{array}$


from selected springs and wells--Continued

Dis-

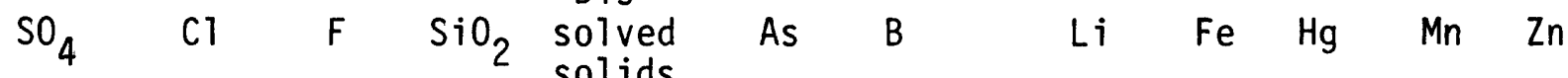

$\begin{array}{llllllllllll}110 & 270 & 10.5 & 240 & 1,270 & 1.2 & 11.0 & 2.6 & 36 & 1.9 & 3 & 4\end{array}$

$\begin{array}{llllllllllll}110 & 270 & 10.5 & 240 & 1,270 & 0.7 & 11.0 & 2.7 & 35 & 1.8 & 24 & <3\end{array}$

$\begin{array}{llllllllllll}11 & 15 & 0.4 & 53 & 182 & 0.05 & 0.36 & 0.10 & 46 & 0.2 & 22 & 35\end{array}$

$\begin{array}{llllllllllll}10 & 10 & -- & 50 & 125 & 0.02 & 0.4 & -- & 20 & <1 & -- & 30\end{array}$

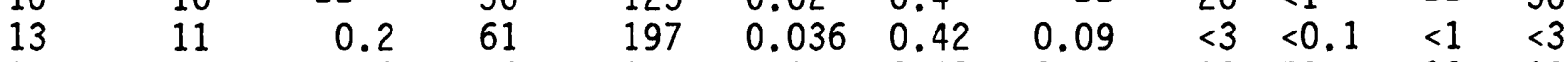

$\begin{array}{lllllllllll}10.5 & 12.1 & 0.3 & 56 & 190 & <0.1 & 0.48 & 0.07 & <20<50 & <10 & <10\end{array}$

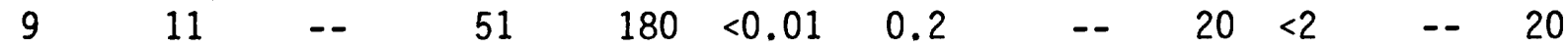

$\begin{array}{rlllllllllll}11 & 3.9 & 0.3 & 57 & 167 & 0.039 & 0.20 & 0.063 & 3 & -- & 1 & 3 \\ 8 & 4 & -- & 46 & 170 & 0.01 & 0.3 & -- & 40 & <2 & -- & 1\end{array}$

$\begin{array}{llllllllllll}11 & 2.1 & 0.3 & 51 & 143 & 0.036 & 0.12 & 0.046 & <3 & -- & <1 & 4\end{array}$

$\begin{array}{lllllllllll}10 & 1.7 & 0.2 & 40 & 118 & 0.023 & 0.080 & 0.030 & <3 & <0.1 & <1\end{array}$

$\begin{array}{llllllllllll}120 & 244 & 10.6 & 215 & 1,271 & 1.5 & 11.1 & 3.0 & <20<50 & 200 & 10\end{array}$

$\begin{array}{lllllllllll}111 & 233 & 9.8 & 173 & 1,109 & 1.3 & 10.6 & 3.0 & <20<50 & <20 & 10\end{array}$

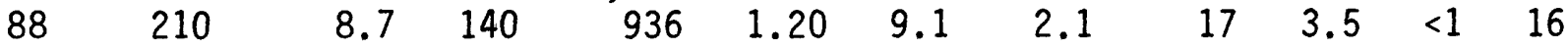

$\begin{array}{llllllllllll}95 & 210 & 8.1 & 160 & 929 & 0.76 & 8.7 & 1.6 & 27 & -- & 100 & 19\end{array}$

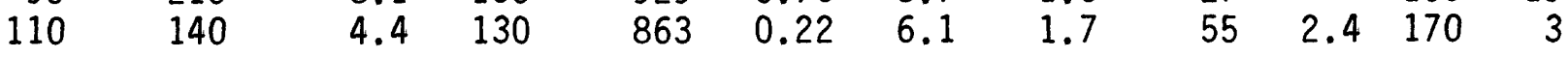

$\begin{array}{rrrrrrrrrrrr}100 & 220 & 9.5 & 180 & 1,130 & 0.98 & 9.5 & 2.3 & <3 & <0.1 & 12 & 7 \\ -- & 230 & -- & 140 & -- & -- & 10.0 & -- & -- & -- & -- & --\end{array}$

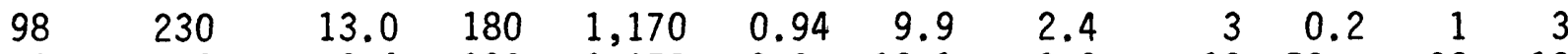

$\begin{array}{rrrrlllllrrr}92 & 209 & 9.4 & 139 & 1,175 \mathrm{c} & 0.9 & 10.1 & 2.9 & <10 & <50 & <20 & <10 \\ 98 & 220 & 9.7 & 140 & 1,190 & 1.10 & 10.0 & 2.5 & <3 & 0.4 & 3 & 4\end{array}$

$\begin{array}{rrrrlllllllr}95 & 210 & 7.9 & 100 & 1,210 & 0.60 & 8.7 & 2.70 & 37 & 0.1 & 200 & 8 \\ 95 & 199 & 7.7 & 88 & 1,230 \mathrm{c} & 0.6 & 8.9 & 3.00 & 40 & <50 & 220 & <10\end{array}$ 
TABLE 1.--Chemical analyses of water

\begin{tabular}{|c|c|c|c|c|c|c|c|c|c|}
\hline $\begin{array}{c}\text { Feature } \\
\text { (designation) }\end{array}$ & $\begin{array}{l}\text { Collec- } \\
\text { tion } \\
\text { date }\end{array}$ & $\begin{array}{l}\text { Labor- } \\
\text { atory }\end{array}$ & $\begin{array}{l}\text { Temper- } \\
\text { a ture } \\
\left({ }^{\circ} \mathrm{C}\right)\end{array}$ & $\mathrm{pH}$ & $\mathrm{Ca}$ & $\mathrm{Mg}$ & $\mathrm{Na}$ & $k$ & $\begin{array}{l}\text { Alka- } \\
\text { linity }\end{array}$ \\
\hline
\end{tabular}

Springs along caldera margin or outside caldera

\begin{tabular}{|c|c|c|c|c|c|c|c|c|c|}
\hline $\begin{array}{c}\text { Laurel Spring } \\
\text { (LS) }\end{array}$ & $\begin{array}{l}02-02-85 \\
05-26-85\end{array}$ & $\begin{array}{l}\text { USGS-C } \\
\text { LANL }\end{array}$ & $\begin{array}{l}12.0 \\
11.8\end{array}$ & $\begin{array}{l}8.9 \\
8.6\end{array}$ & $\begin{array}{l}17 \\
15.7\end{array}$ & $\begin{array}{l}0.60 \\
0.59\end{array}$ & $\begin{array}{l}6.2 \\
6.1\end{array}$ & $\begin{array}{l}1.3 \\
1.2\end{array}$ & $\begin{array}{l}38 \\
38 \mathrm{~L}\end{array}$ \\
\hline Big Spring (BS) & $07-18-85$ & USGS-C & 11.5 & 7.1 & 5.3 & 6.6 & 24 & 4.0 & 81 \\
\hline $\begin{array}{l}\text { Reds Meadow Tub } \\
\text { spring (RMT) }\end{array}$ & $07-18-85$ & $\begin{array}{l}\text { USGS-C } \\
\text { LANL }\end{array}$ & $\begin{array}{l}47.9 \\
47.9\end{array}$ & & $\begin{array}{l}69 \\
64\end{array}$ & $\begin{array}{l}2.3 \\
2.3\end{array}$ & $\begin{array}{l}140 \\
134\end{array}$ & $\begin{array}{l}5.7 \\
5.7\end{array}$ & $\begin{array}{l}426 \\
403 \mathrm{~L}\end{array}$ \\
\hline $\begin{array}{l}\text { Devils Postpile } \\
\text { Soda Spring } \\
\text { (SSP) }\end{array}$ & $\begin{array}{l}{ }^{4} 11-16-77 \\
{ }^{4} 10-02-84\end{array}$ & $\begin{array}{l}\text { USGS-M } \\
\text { LANL }\end{array}$ & $\begin{array}{r}8 \\
13\end{array}$ & $\begin{array}{l}6.1 \\
6.3\end{array}$ & $\begin{array}{r}130 \\
43\end{array}$ & $\begin{array}{l}32 \\
26\end{array}$ & $\begin{array}{l}400 \\
485\end{array}$ & $\begin{array}{l}20 \\
19\end{array}$ & $\begin{array}{l}1040 \\
861 \mathrm{~L}\end{array}$ \\
\hline
\end{tabular}

${ }^{1}$ Total-flow sample--collected by condensing single-phase flow in discharge pipe through stainless-steel tubing in ice bath.

${ }^{2}$ Total flow of two-phase fluid at 4.5 psig (pounds per square inch--gage) and $104{ }^{\circ} \mathrm{C}$ collected through separator at same conditions, 4.4 percent steam fraction; analys is is for separate water.

${ }^{3}$ Total flow of two-phase fluid at $4.5 \mathrm{psig}$ and $104{ }^{\circ} \mathrm{C}$ collected through stainless-steel tubing in ice bath; analys is is for total-flow sample.

41977 and 1984 samples may have been collected from different vents in same general area. 
from selected springs and wells--Continued

\begin{tabular}{|c|c|c|c|c|c|c|c|c|c|c|c|}
\hline $\mathrm{SO}_{4}$ & $\mathrm{Cl}$ & $F$ & $\mathrm{SiO}_{2}$ & $\begin{array}{l}\text { Dis- } \\
\text { solved } \\
\text { solids }\end{array}$ & As & B & Li & $\mathrm{Fe}$ & $\mathrm{Hg}$ & $M n$ & $\mathrm{Zn}$ \\
\hline
\end{tabular}

$\begin{array}{rlllllllllrr}19.0 & 0.6 & 0.2 & 22 & 85 & 0.001 & 0.020 & 0.004 & 7 & <0.1 & <1 & 6 \\ 18.4 & 2.0 & 0.12 & 21 & 91 & 0.2 & 0.04 & <0.01 & <10 & <50 & <10 & <10\end{array}$

$\begin{array}{llllllllllll}6.4 & 4.5 & 0.5 & 60 & 147 & 0.022 & 0.26 & 0.038 & <3 & <0.1 & 2 & 4\end{array}$

$\begin{array}{llllllllllll}28.0 & 6.9 & 4.7 & 150 & 616 & 0.010 & 1.7 & 0.85 & <3 & <0.1 & 550 & 18\end{array}$

$\begin{array}{lllllllllll}29.5 & 6.2 & 4.6 & 149 & 610 & 0.4 & 1.8 & 0.89 & 10<100 & 570 & 20\end{array}$

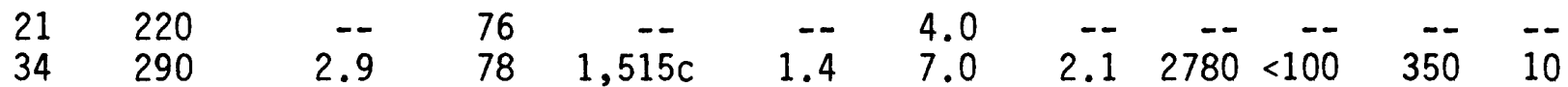


TABLE 2.--Isotopic analyses of water and gas from selected springs, fumaroles, and wells

Results represent ratios of deuterium to hydrogen $(\delta D)$ in water, oxygen 18 to oxygen $16\left(\delta^{18} 0\right)$ in water, and carbon 13 to carbon $12\left(\delta^{13} \mathrm{C}\right)$ in water and gas expressed in standard delta notation in parts per thousand $(0 / 00)$. WA, waiting for completion of laboratory analysis; --, no data.

Feature: Name of sample site and (in parentheses) designation used in figures and tables throughout report.

Laboratory: USGS-m1, U.S. Geological Survey, Men1o Park, CA (C. Janik); USGS-m2, U.S. Geological Survey, Menlo Park, CA (R. Mariner); LBL, Lawrence Berkeley Laboratory, Berkeley, CA (A. White); USGS-R, U.S. Geological Survey Laboratory, Reston, VA (T. Coplen); USGS-C, U.S. Geological Survey Central Laboratory, Arvada, CO

\begin{tabular}{|c|c|c|c|c|c|c|}
\hline $\begin{array}{c}\text { Feature } \\
\text { (designation) }\end{array}$ & $\begin{array}{c}\text { Collection } \\
\text { date }\end{array}$ & Laboratory & $\begin{array}{c}\delta D \\
(0 / 00)\end{array}$ & $\begin{array}{l}\delta^{180} \\
(0 / 00)\end{array}$ & $\begin{array}{l}\delta^{13} \mathrm{C} \\
(0 / 00)\end{array}$ & $\begin{array}{l}\text { Comments } \\
\text { (phase) }\end{array}$ \\
\hline
\end{tabular}

Casa Diablo area - springs and fumaroles in secs. 32 and $33 ;$ T. 3 S., R. 28 E.

\begin{tabular}{lllr|rrr} 
Colton Spr. & $02-05-85$ & USGS-R & -115 & -14.2 & -4.1 & liquid \\
(CS) & $05-26-85$ & USGS-m1 & -115 & -14.2 & -3.0 & liquid \\
& & & -- & -- & -12.8 & gas \\
Colton Fuma- & $05-26-85$ & USGS-m1 & -- & -- & -8.8 & gas \\
role (CF)1 & & & & & & \\
$\begin{array}{l}\text { North Spring } \\
\text { (CDNS) }\end{array}$ & $02-06-85$ & USGS-R & -115 & -14.0 & -6.8 & liquid \\
$\begin{array}{l}\text { Milky Pool 3 } \\
\text { (MP-3) }\end{array}$ & $07-16-85$ & USGS-R & -115 & -14.1 & -3.7 & liquid \\
$\quad 07-16-85$ & USGS-R & -115 & -13.9 & -4.2 & liquid \\
$\begin{array}{l}\text { Meadow Spring } \\
\text { (MS) }\end{array}$ & $05-26-85$ & USGS-C & -118 & -13.8 & -2.2 & liquid \\
Geyser (CDG) & $05-29-85$ & USGS-m1 & -121 & -13.7 & -3.1 & liquid \\
Clay Pit Fuma- & $05-29-85$ & USGS-m1 & -114 & -13.5 & -4.0 & liquid \\
role (CDF) & & & -152 & -21.0 & -6.5 & gas
\end{tabular}

Casa Diablo area - wells in secs. 32 and 33, T. 3 S., R. 28 E. Well (MBP-1) ${ }^{205-29-85}$ USGS-m1 WA 17.7 - WA

\begin{tabular}{rrr|rr}
${ }^{3} 07-11-85$ & & -128 & -17.7 & -5.0 \\
& & -116 & -14.2 & -4.5 \\
${ }^{4} 07-11-84$ & USGS-C & -117 & -14.8 & -4.3 \\
${ }^{4} 07-11-85$ & USGS-m1 & -118 & -14.7 & -5.2 \\
& & -- & -- & -6.2
\end{tabular}

separated gas separated liquid separated gas separated liquid total-flow liquid total-flow liquid

See footnotes at end of table. 
TABLE 2.--Isotopic analyses of water and gas from selected springs, fumaroles, and wells--Continued

\begin{tabular}{|c|c|c|c|c|c|c|}
\hline $\begin{array}{c}\text { Feature } \\
\text { (designation) }\end{array}$ & $\begin{array}{l}\text { Collection } \\
\text { date }\end{array}$ & Laboratory & $\begin{array}{c}\delta D \\
(0 / 00)\end{array}$ & $\begin{array}{l}\delta^{18} 0 \\
(0 / 00)\end{array}$ & $\begin{array}{l}\delta^{13} \mathrm{C} \\
(0 / 00)\end{array}$ & $\begin{array}{r}\text { Comments } \\
\text { (phase) }\end{array}$ \\
\hline
\end{tabular}

Casa Diablo area - wells in secs. 32 and 33, T. 3 S., R. 28 E.--Continued

\begin{tabular}{|c|c|c|c|c|c|c|}
\hline Well $(\mathrm{MBP}-3)$ & $\begin{array}{l}{ }^{3} 07-12-85 \\
{ }^{4} 07-12-85 \\
{ }^{4} 07-12-85\end{array}$ & $\begin{array}{l}\text { USGS-C } \\
\text { USGS-m1 }\end{array}$ & $\begin{array}{r}-127 \\
-118 \\
\text { WA } \\
\text { WA } \\
-116 \\
\text { WA } \\
--\end{array}$ & $\begin{array}{r}-18.3 \\
-14.6 \\
-17.6 \\
-14.7 \\
-14.8 \\
\text { WA } \\
--\end{array}$ & $\begin{array}{l}-5.3 \\
-5.4 \\
-4.6 \\
-5.9 \\
-4.4 \\
-5.0 \\
-5.8\end{array}$ & $\begin{array}{l}\text { separated gas } \\
\text { separated liquid } \\
\text { separated gas } \\
\text { separated liquid } \\
\text { total-flow liquid } \\
\text { total-flow liquid } \\
\text { total-flow gas }\end{array}$ \\
\hline We11 (MBP-4) & ${ }^{4} 10-13-85$ & USGS-C & WA & WA & WA & total-flow liquid \\
\hline Well (MBP-5) & ${ }^{4} 10-13-85$ & USGS-C & -115 & -14.4 & -5.9 & total-flow liquid \\
\hline $\begin{array}{l}\text { Sheriff's Sta- } \\
\text { tion well } \\
\text { (SS-2) }\end{array}$ & $07-16-85$ & USGS-C & -114 & -15.0 & -- & liquid \\
\hline
\end{tabular}

Fish Hatchery area - springs and wells in secs. 34 and $35, T .3$ S., R. 28 E.

\begin{tabular}{|c|c|c|c|c|c|c|}
\hline $\begin{array}{l}\text { Supply spring } \\
(A B)\end{array}$ & $04-28-85$ & USGS-R & -115 & -15.2 & -- & liquid \\
\hline $\begin{array}{l}\text { Supply spring } \\
\text { (CD) }\end{array}$ & $04-28-85$ & USGS-R & -118 & -15.8 & -- & liquid \\
\hline $\begin{array}{r}\text { Springs } \\
(H-I)\end{array}$ & $04-28-85$ & USGS-R & -120 & -16.1 & -- & liquid \\
\hline$(H-I I, I I I)$ & $04-28-85$ & USGS-R & -123 & -16.5 & -- & liquid \\
\hline $\begin{array}{l}\text { Hot Bubbling } \\
\text { Pool (HBP) }\end{array}$ & $05-28-85$ & USGS-m1 & $\begin{array}{r}-113 \\
--\end{array}$ & $\begin{array}{r}-13.2 \\
--\end{array}$ & $\begin{array}{l}-3.2 \\
-5.3\end{array}$ & $\begin{array}{l}\text { liquid } \\
\text { gas }\end{array}$ \\
\hline $\begin{array}{c}\text { Chance } \\
\text { Noll } \\
\text { (CW-2) }\end{array}$ & $\begin{array}{l}505-28-85 \\
{ }^{6} 06-03-85\end{array}$ & USGS-m1 & $\begin{array}{l}-117 \\
-140 \\
-121\end{array}$ & $\begin{array}{l}-14.3 \\
-18.9 \\
-15.2\end{array}$ & $\begin{array}{l}-3.5 \\
-6.5 \\
-6.9\end{array}$ & $\begin{array}{l}\text { separated liquid } \\
\text { separated gas } \\
\text { total-flow liquid }\end{array}$ \\
\hline
\end{tabular}

Hot Creek Gorge area - springs and geysers in sec. $25, T .3$ S., R. 28 E.

\begin{tabular}{|c|c|c|c|c|c|c|}
\hline $\begin{array}{l}\text { Spring above } \\
\text { bridge (HC-2) }\end{array}$ & $\begin{array}{l}02-04-85 \\
07-16-85\end{array}$ & $\begin{array}{l}\text { USGS-R } \\
\text { USGS-C }\end{array}$ & $\begin{array}{l}-119 \\
-120\end{array}$ & $\begin{array}{l}-14.6 \\
-14.7\end{array}$ & -3.9 & $\begin{array}{l}\text { Tiquid } \\
\text { liquid }\end{array}$ \\
\hline Geyser (HC-3) & $\begin{array}{l}02-04-85 \\
07-16-85\end{array}$ & $\begin{array}{l}\text { USGS-R } \\
\text { USGS-C }\end{array}$ & $\begin{array}{l}-119 \\
-119\end{array}$ & $\begin{array}{l}-14.9 \\
-15.2\end{array}$ & $\begin{array}{l}-4.6 \\
-3.4\end{array}$ & $\begin{array}{l}\text { liquid } \\
\text { liquid }\end{array}$ \\
\hline Geyser $(\mathrm{HC}-4)$ & $05-29-85$ & USGS-m1 & -121 & $\begin{array}{r}-14.9 \\
\ldots-\end{array}$ & $\begin{array}{l}-3.8 \\
-5.0\end{array}$ & $\begin{array}{l}\text { liquid } \\
\text { gas }\end{array}$ \\
\hline
\end{tabular}

See footnotes at end of table. 
TABLE 2.--Isotopic analyses of water and gas from selected springs, fumaroles, and wells--Continued

\begin{tabular}{|c|c|c|c|c|c|c|}
\hline $\begin{array}{c}\text { Feature } \\
\text { (designation) }\end{array}$ & $\begin{array}{c}\text { Collection } \\
\text { date }\end{array}$ & Laboratory & $\begin{array}{c}\delta D \\
(0 / 00)\end{array}$ & $\begin{array}{l}\delta^{180} \\
(0 / 00)\end{array}$ & $\begin{array}{l}\delta^{13} C \\
(0 / 00)\end{array}$ & $\begin{array}{r}\text { Comments } \\
\text { (phase) }\end{array}$ \\
\hline
\end{tabular}

Little Hot Creek area - springs in sec. 13, T. 3 S., R. 28 E.

$\begin{array}{crlrrrl}\text { Flume Spring } & 03-21-85 & \text { USGS-R } & -124 & -15.7 & -4.5 & \text { liquid } \\ (\text { LHC-1) } & 05-25-85 & \text { USGS-m1 } & \text { WA } & -15.6 & -4.3 & \text { liquid } \\ & & & -- & -- & -6.4 & \text { gas }\end{array}$

Cold springs along caldera margin

$\begin{array}{lrlrrrr}\text { Laurel Spring } & 02-06-85 & \text { USGS-R } & -126 & -17.1 & -- & \text { liquid } \\ (\text { LS) } & 05-26-85 & \text { USGS-m1 } & -127 & -17.0 & -11.6 & \text { liquid }\end{array}$

$\begin{array}{crlrrrr}\text { Big Spring } & 05-29-85 & \text { USGS-mI } & \text { WA } & -15.8 & -8.8 & \text { liquid } \\ \text { (BS) } & 07-18-85 & \text { USGS-R } & -115 & -15.7 & -- & \text { liquid }\end{array}$

Springs outside Long Valley caldera

$\begin{array}{lllrrrl}\begin{array}{l}\text { Reds Meadow } \\ \text { Tub Spring } \\ \text { (RMT) }\end{array} & 07-18-85 & \text { USGS-R } & -112 & -15.2 & -5.6 & \text { liquid } \\ & & & & & & \\ \text { Devils } & 711-16-77 & \text { USGS-m2 } & -107 & -14.8 & -4.2 & \text { liquid } \\ \text { Postpile } & & -- & -5.8 & \text { gas } \\ \text { Soda Spring } & { }^{7} 10-02-84 & \text { USGS-m1 } & -108 & -14.6 & -5.6 & \text { liquid } \\ \text { (SSP) } & & & -- & -- & -8.8 & \text { gas }\end{array}$

ISteam vent 100 feet above Colton Spring.

2Separator conditions: $38 \mathrm{psig}$ (pounds per square inch--gage), $138{ }^{\circ} \mathrm{C}, 6.0$ percent steam fraction for MBP-1; $65 \mathrm{psig}, 154^{\circ} \mathrm{C}, 3.5$ percent steam fraction for MBP-3.

${ }^{3}$ Separator conditions: $65 \mathrm{psig}, 157{ }^{\circ} \mathrm{C}, 2.9$ percent steam fraction for MBP-1; $87 \mathrm{psig}, 164{ }^{\circ} \mathrm{C}, 1.5$ percent steam fraction for MBP-3.

"Total flow of single-phase fluid collected by cooling flow through stainless-steel tubing in ice-and-water bath.

${ }^{5}$ Total flow of two-phase fluid at $4.5 \mathrm{psig}, 104{ }^{\circ} \mathrm{C}$, collected through separator at same conditions, 4.4 percent steam fraction. Gas-phase results are for separated steam-gas fraction; liquid-phase results are for separated water sample.

${ }^{6}$ Total flow of two-phase fluid at $4.5 \mathrm{psig}, 104{ }^{\circ} \mathrm{C}$, condensed through stainless-steel tubing in ice-and-water bath.

${ }^{7} 1977$ and 1984 samples may have been collected from different vents within same general area. 
TABLE 3.--Chemical-geothermometer temperatures for selected well and spring samples

[Laboratory: USGS-M: U.S. Geological Survey, Menlo Park, CA (analyzed by L. Tilley); USGS-C: U.S. Geological Survey Central Laboratory, Arvada, Co; LANL: Los Alamos National Laboratory (analyzed by P. Trujillo and D. Counce); LBL: Lawrence Berkeley Laboratory (A. White)]

\begin{tabular}{|c|c|c|c|c|c|c|}
\hline \multirow{3}{*}{ Site } & \multirow{3}{*}{$\begin{array}{c}\text { Sample } \\
\text { date }\end{array}$} & \multicolumn{5}{|c|}{ Temperatures $\left({ }^{\circ} \mathrm{C}\right)$ based on specified geothermometer ${ }^{1}$} \\
\hline & & Labor= & Quartz- & & Cation & \\
\hline & & atory & conductive & $\overline{\mathrm{Na} / \mathrm{K}}$ & $1 / 3(\mathrm{Na}-\mathrm{K}-\mathrm{Ca})$ & $\mathrm{Mg} / \mathrm{Li}$ \\
\hline
\end{tabular}

Casa Diablo area - wells in secs. 31 and $32, T .3$ S., R. 28 E.

$\begin{array}{lllllll}\text { END-5 } & 05-19-72 & \text { USGS-M } & 219 & 230 & 238 & 201 \\ \text { MBP-1 } & 05-29-85 & \text { LANL } & 203 & 213 & 219 & 213 \\ & 07-11-85 & \text { USGS-C } & 196 & 210 & 205 & 212 \\ & & \text { LANL } & 198 & 224 & 221 & 209 \\ & & \text { LBL } & 224 & 218 & 218 & 204 \\ \text { MBP-3 } & 05-28-85 & \text { LANL } & 200 & 211 & 211 & 204 \\ & 07-12-85 & \text { USGS-C } & 196 & 219 & 224 & 210 \\ & & \text { LANL } & 198 & 226 & 228 & 203 \\ & & \text { LBL } & 213 & 217 & 212 & 204 \\ \text { MBP-4 } & 10-13-85 & \text { USGS-C } & 193 & 220 & 220 & 210 \\ \text { MBP-5 } & 10-13-85 & \text { USGS-C } & 193 & 209 & 200 & 212\end{array}$

Casa Diablo area - springs in secs. 31,32 , and $33, T .3$ S., R. 28 E.

$\begin{array}{lllllll}\text { CDG } & 05-28-85 & \text { LANL } & 209 & 214 & 219 & 241 \\ \text { CDNS } & 02-06-85 & \text { USGS-C } & 198 & 209 & 186 & 124 \\ \text { CS } & 02-04-85 & \text { USGS-C } & 209 & 191 & 201 & 267\end{array}$

Fish Hatchery, Hot Creek Gorge, Little Hot Creek, Reds Meadow - springs and wells

\begin{tabular}{lllllll}
\hline CW-2 & $05-28-85$ & LANL & 170 & 171 & 180 & 206 \\
& $06-03-85$ & USGS-C & 157 & 187 & 194 & 200 \\
CMS & $01-16-85$ & USGS-C & 165 & 138 & 148 & 140 \\
& $10-18-85$ & USGS-C & 152 & 136 & 142 & 126 \\
HC-2 & $02-04-85$ & USGS-C & 173 & 177 & 177 & 189 \\
HC-3 & $02-04-85$ & USGS-C & 173 & 177 & 187 & 191 \\
LHC-1 & $03-21-85$ & USGS-C & 137 & 188 & 174 & 168 \\
RMT & $07-18-85$ & USGS-C & 161 & 150 & 125 & 111 \\
\hline
\end{tabular}

${ }^{1}$ See text for equations used in calculations. 


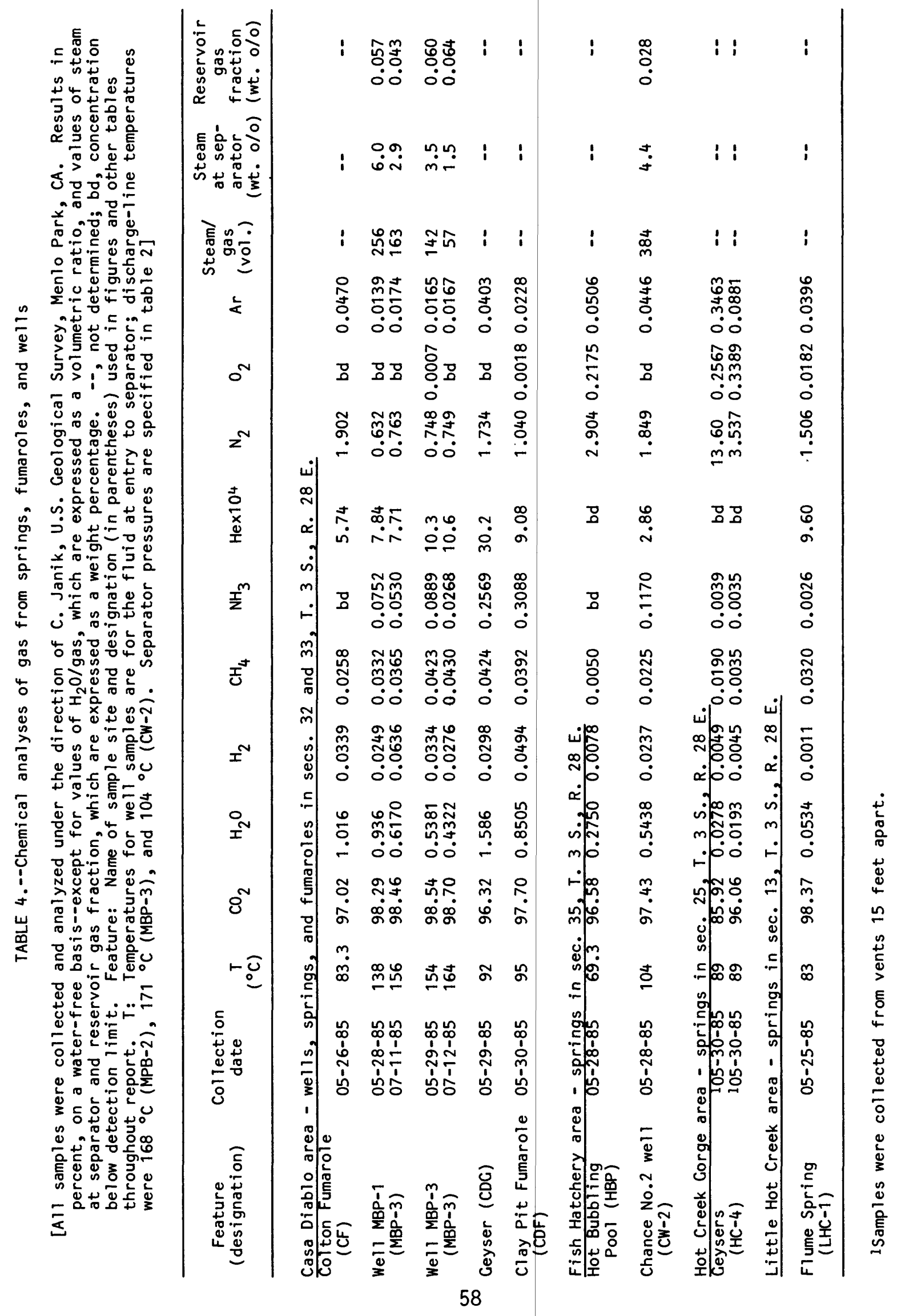



TABLE 5.--Ratios of ${ }^{3} \mathrm{HE} / 4 \mathrm{He}$ relative to air in helium gas from
various thermal features

[Samples collected by and analyzed under the direction of W. Rison (New Mexico Institute of Mining and Technology), except those shown with *, which were collected and analyzed under the direction of R. Poreda (Scripps Institute of Oceanography), and those shown with **, which were collected and analyzed under the direction of B.M. Kennedy (University of California at Berkeley). Values listed are corrected for air using measured He/Ne ratio. --, not sampled]

Feature
(designation)

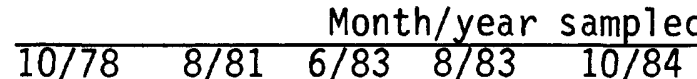

Reds Meadow Tub spring (RMT)

Soda Spring at Devils Postpile (SSP)

Mammoth Mountain

Fumarole (MMN)

We11 MBP-1

We11 MBP-3

Casa Diablo geyser (CDG)

Clay Pit Fumarole (CDF)

Colton Fumarole (CS) ${ }^{1}$

Hot Bubbling Pool (HBP)

Hot Creek geysers (HC-3)

Hot Creek geysers (HC-4)

$\begin{array}{llll}4.8 & 5.2 & 5.7 & 5.5\end{array}$

2.5

$5 / 85$

$7 / 85$ 


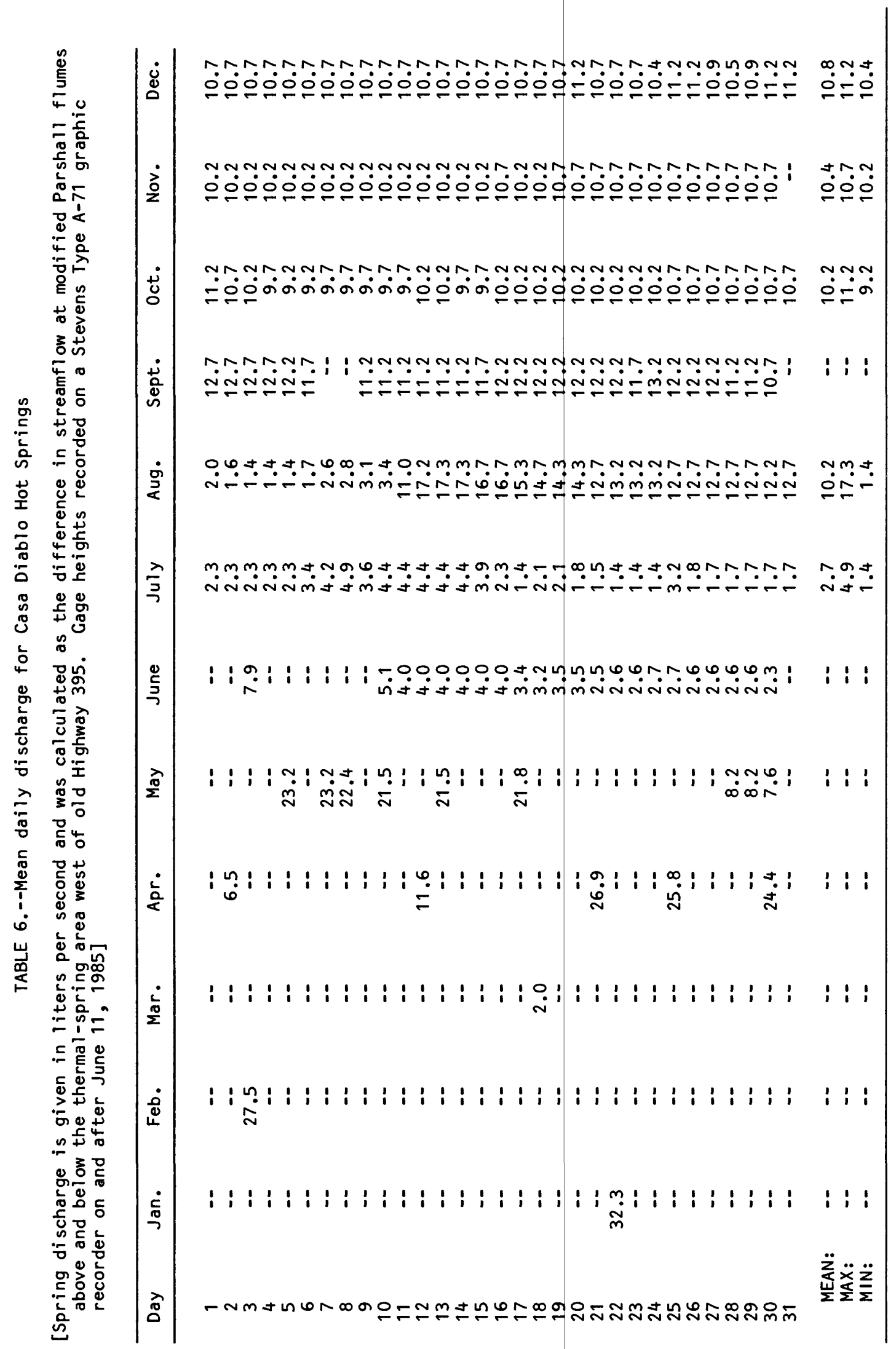




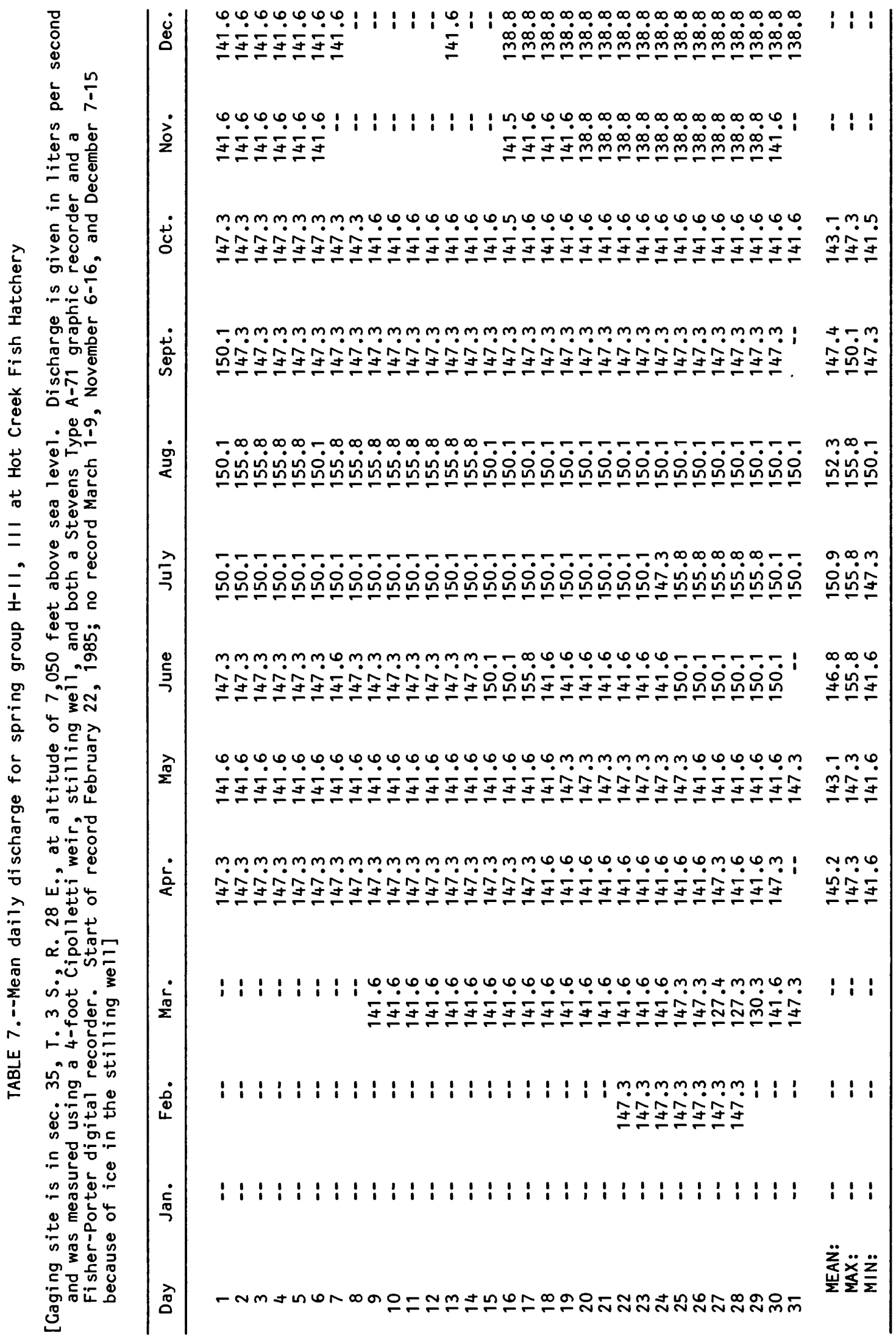




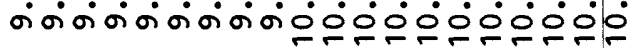

O6000NNNNNNNG0000600N0000000000

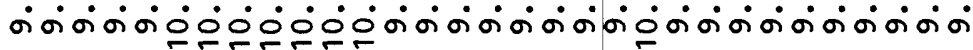

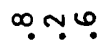

$000000000 \times \infty 00000000000000000001$

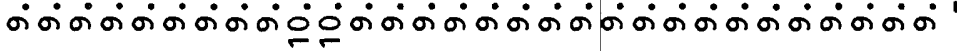

$\because \infty \varphi$ ตㅇํ

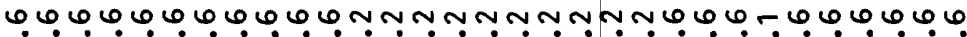

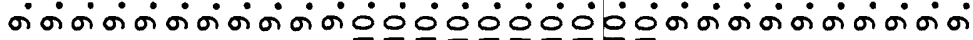

อุกา 으음

$\varphi \varphi \varphi \varphi \varphi \varphi \varphi \varphi \varphi \varphi \varphi \varphi \varphi \varphi \varphi \varphi \varphi \varphi \varphi \varphi \varphi \varphi \varphi \varphi \varphi \varphi \varphi \varphi \varphi \varphi$

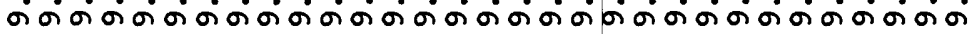

606 कisं

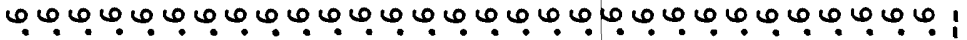

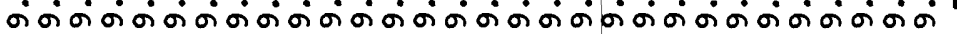

0.0

NNNNNNNNN0000000000000000000000

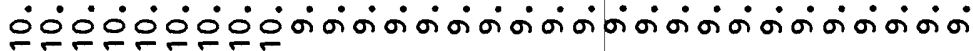

$9 \div 0$ ตㅇํํ סió,

$+\infty n$ 웅ㅇㅇ

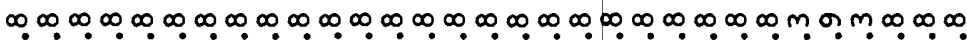

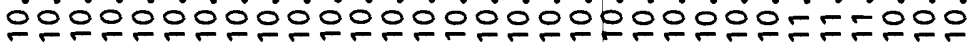

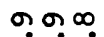
$\therefore \div 0$

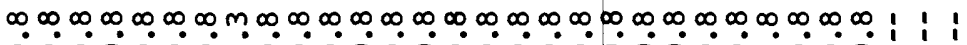
웅ㅇㅇㅇㅇㅇㅇㅇㅇㅇㅇㅇㅇㅇㅇㅇㅇㅇㅇㅇㅇㅇㅇㅇㅇㅇㅇㅇㅁ

$\infty m \infty$ 읃ㅇㅇ

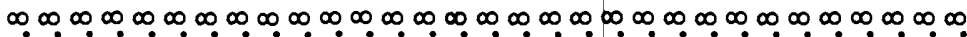

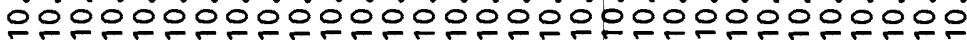

$\infty \infty \infty$ 웅ㅇㅇ

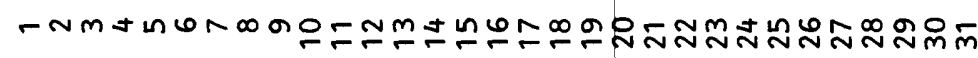




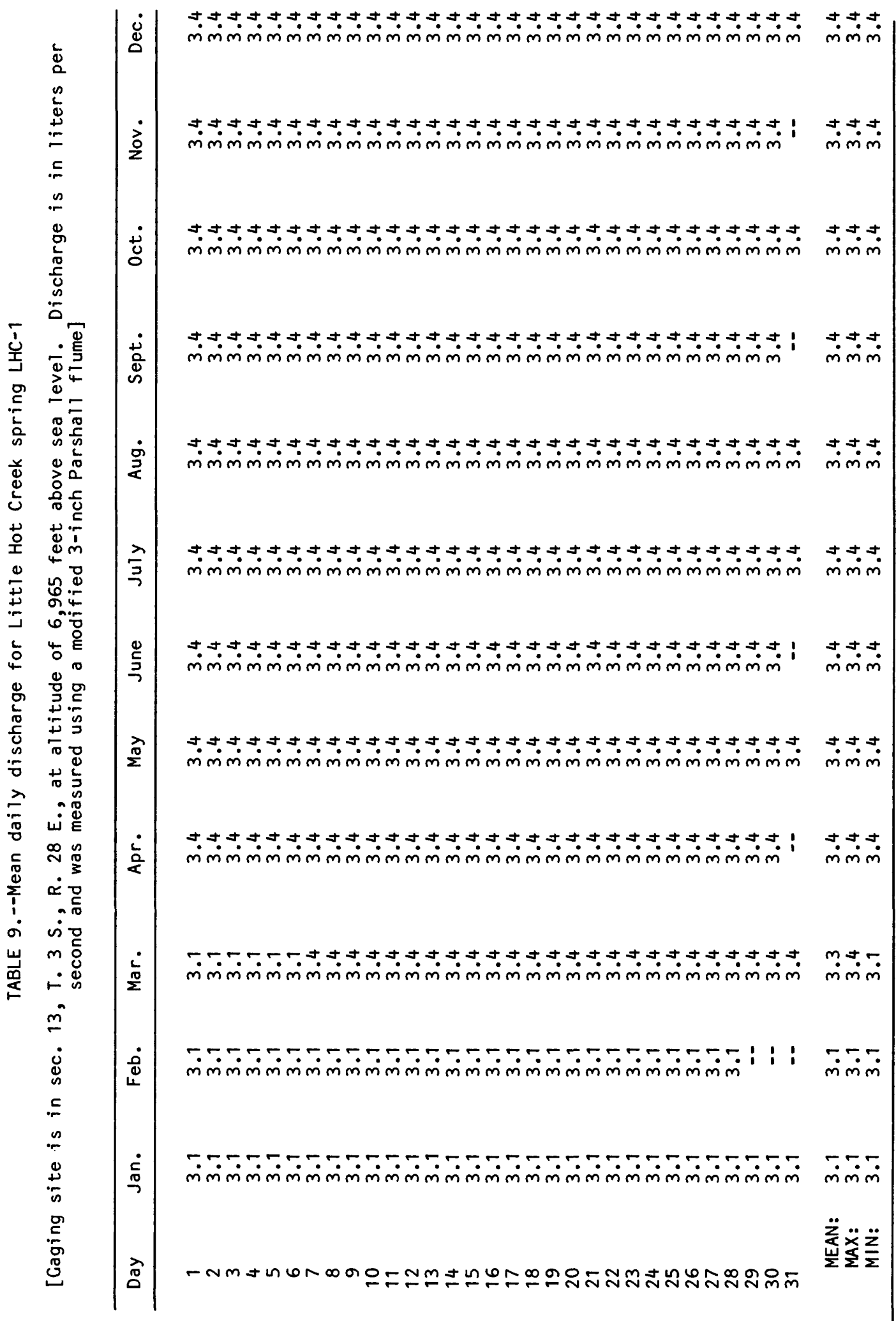




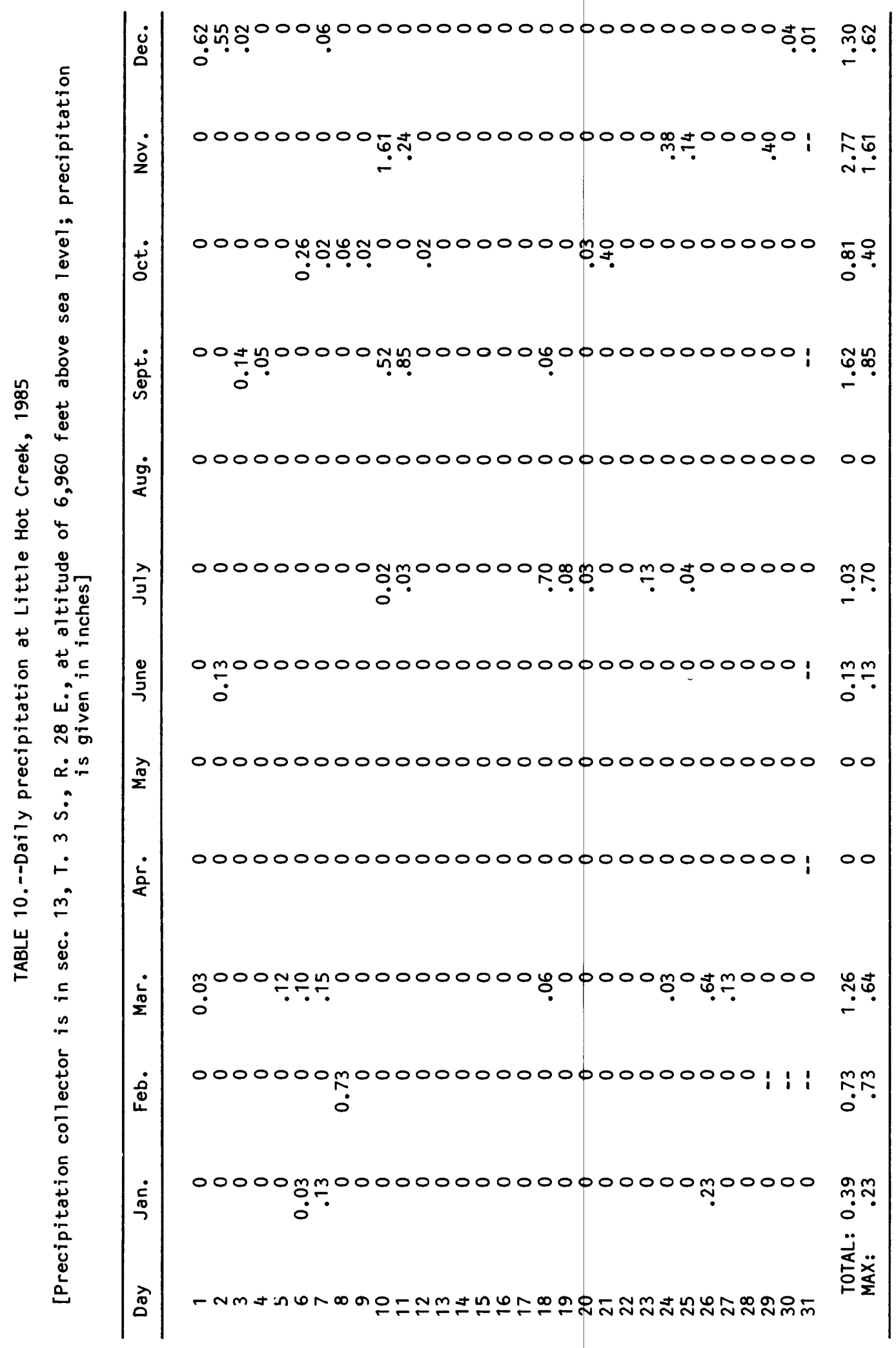




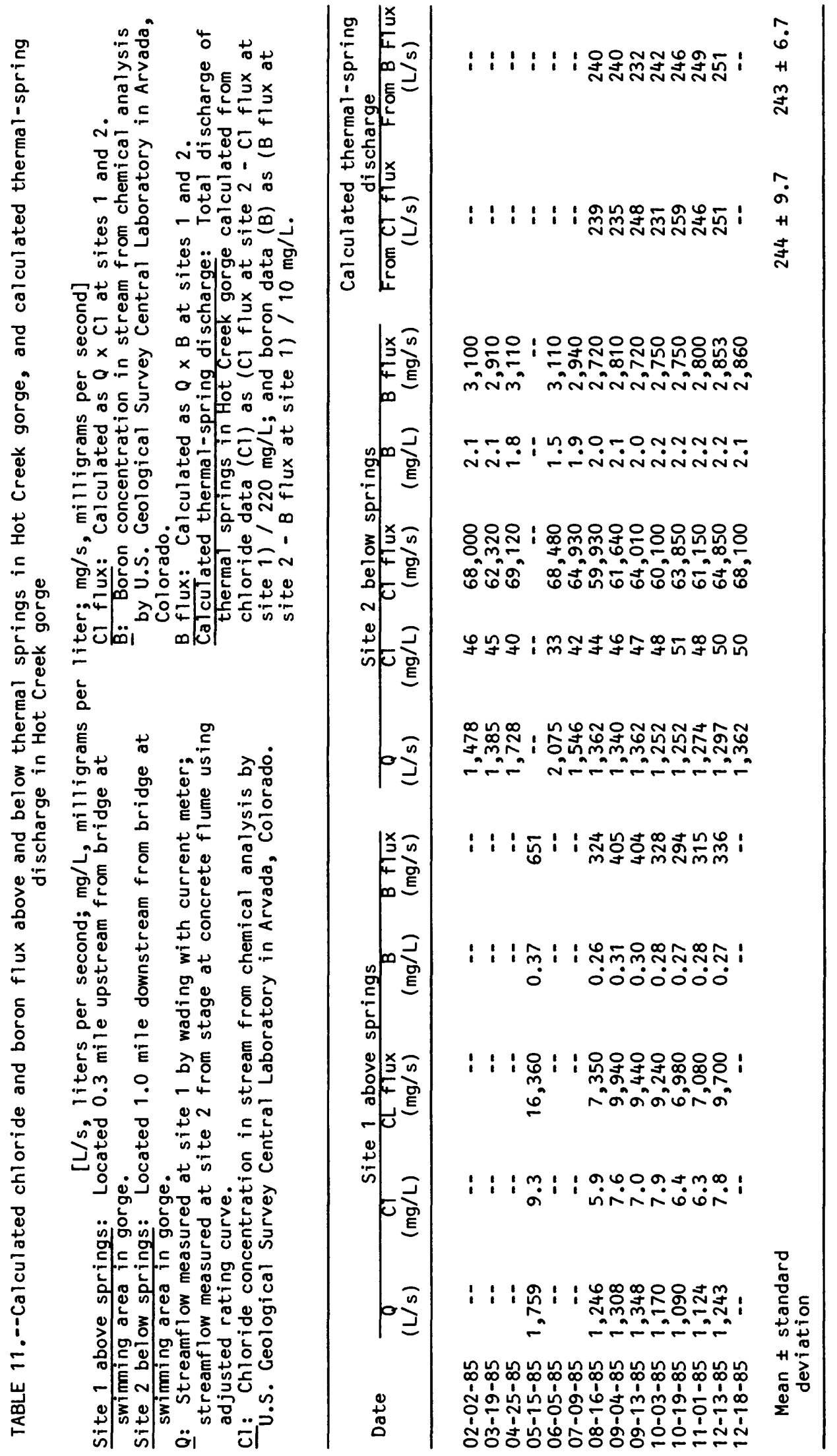


TABLE 12.--Measured and estimated chloride discharge from thermal springs west of Hot Creek gorge, autumn 1985

$[\mathrm{L} / \mathrm{s}$, liters per second; $\mathrm{mg} / \mathrm{L}$, milligrams per liter; $\mathrm{mg} / \mathrm{s}, \mathrm{milligrams}$ per second]

\begin{tabular}{|c|c|c|c|c|}
\hline $\begin{array}{l}\text { Spring } \\
\text { group }\end{array}$ & $\begin{array}{l}\text { Total } \\
\text { flow } \\
(L / s)\end{array}$ & $\begin{array}{l}\text { Average } \\
\text { chloride } \\
\text { concentration } \\
(\mathrm{mg} / \mathrm{L})\end{array}$ & $\begin{array}{l}\text { Chloride } \\
\text { discharge } \\
\text { (mg/s) }\end{array}$ & $\begin{array}{c}\text { Thermal } \\
\text { component } \\
(\mathrm{L} / \mathrm{s})\end{array}$ \\
\hline $\begin{array}{l}\text { Fish Hatchery } \\
\text { Casa Diablo } \\
\text { Hot Bubbling Pool } \\
\text { Colton Spring } \\
\text { Meadow Spring } \\
\text { Total }\end{array}$ & $\begin{array}{r}21,020 \\
310 \\
45 \\
50.7 \\
60 \\
1,035.7\end{array}$ & $\begin{array}{l}4.6 \\
270 \\
244 \\
270 \\
210 \\
-\end{array}$ & $\begin{array}{r}4,700 \\
2,600 \\
1,200 \\
180 \\
0 \\
8,680\end{array}$ & $\begin{array}{r}17.4 \\
9.6 \\
4.4 \\
0.7 \\
0 \\
32.1\end{array}$ \\
\hline
\end{tabular}

${ }^{1}$ Total flow $\times \mathrm{Cl}$ concentration/270.

2Measured July 1984 (Farrar and others, 1985, p. 41).

${ }^{3}$ Figure 4.

${ }^{4}$ Estimated subsurface discharge based on the rate of thermal-water upflow that must $\mathrm{coO} 7$ from $130{ }^{\circ} \mathrm{C}$ to $60^{\circ} \mathrm{C}$ to sustain a heat loss by radiation and evaporation of $1.3(\mathrm{Kcal} / \mathrm{s}) / \mathrm{m}^{2}$ and an evaporation rate of $36 \mathrm{~m} / \mathrm{yr}$ over a pool area of $650 \mathrm{~m}^{2}$.

5 Measured with 45-degree V-notch weir.

${ }^{6}$ No surface flow during autumn 1985. 


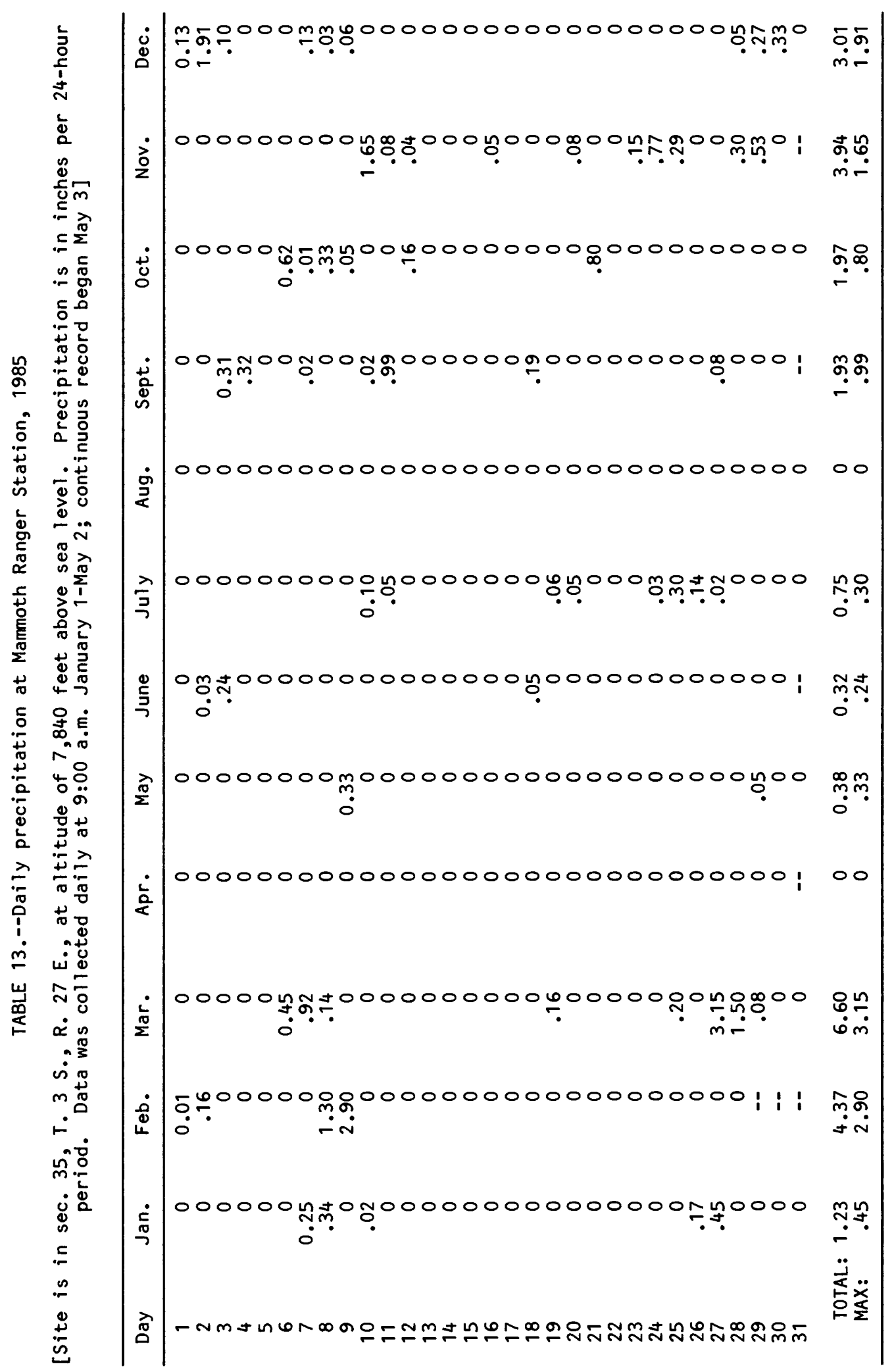




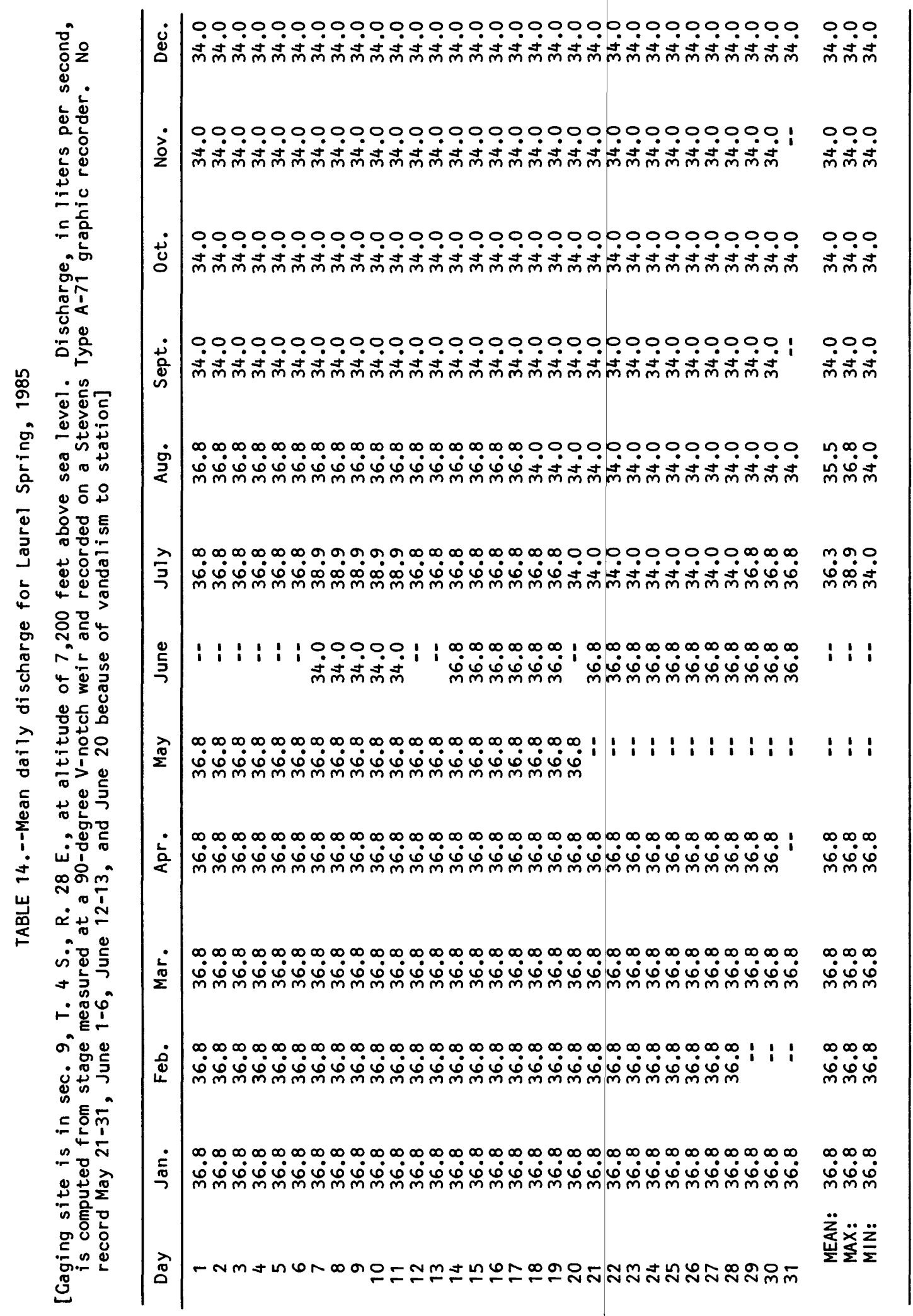




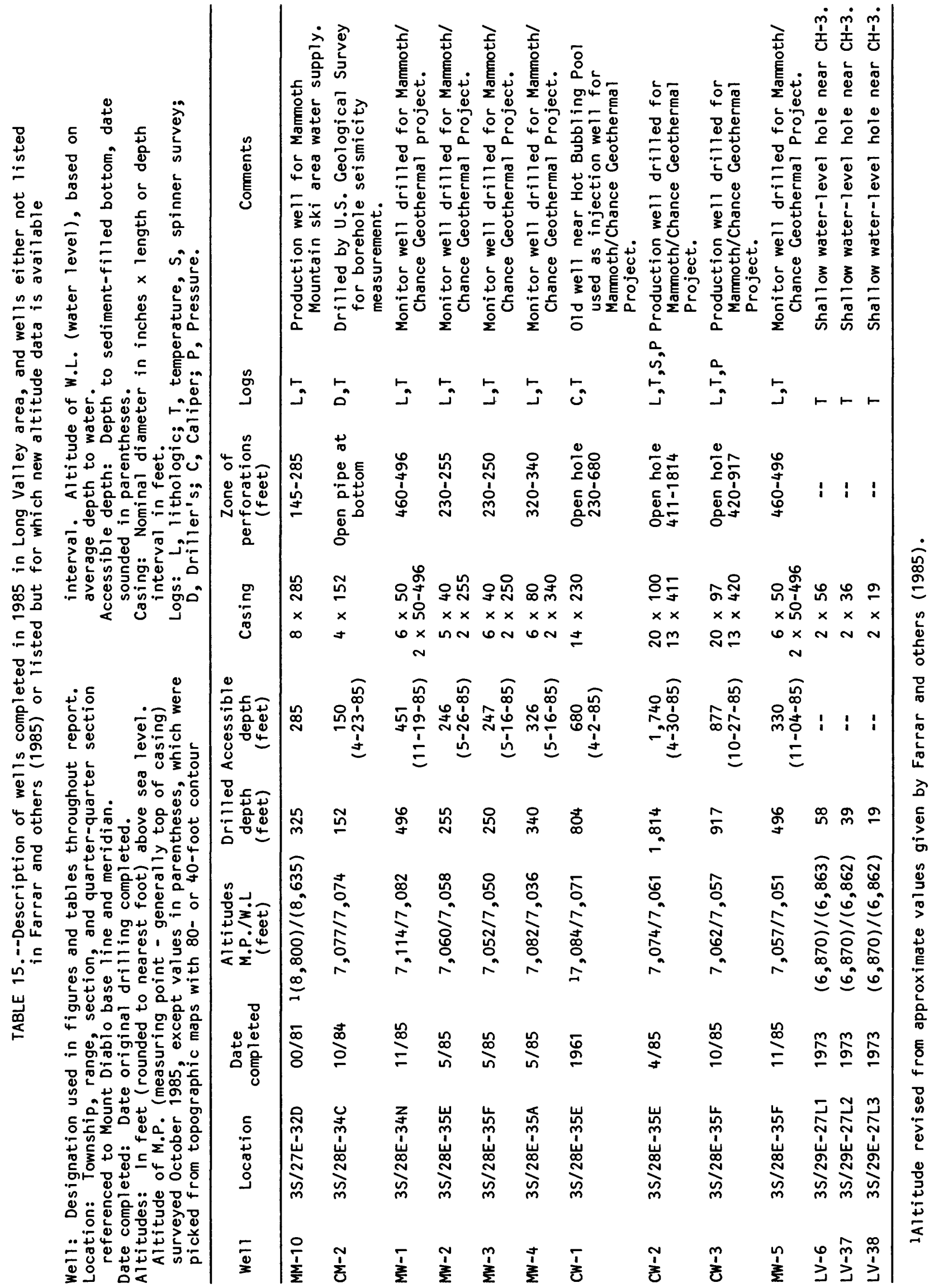




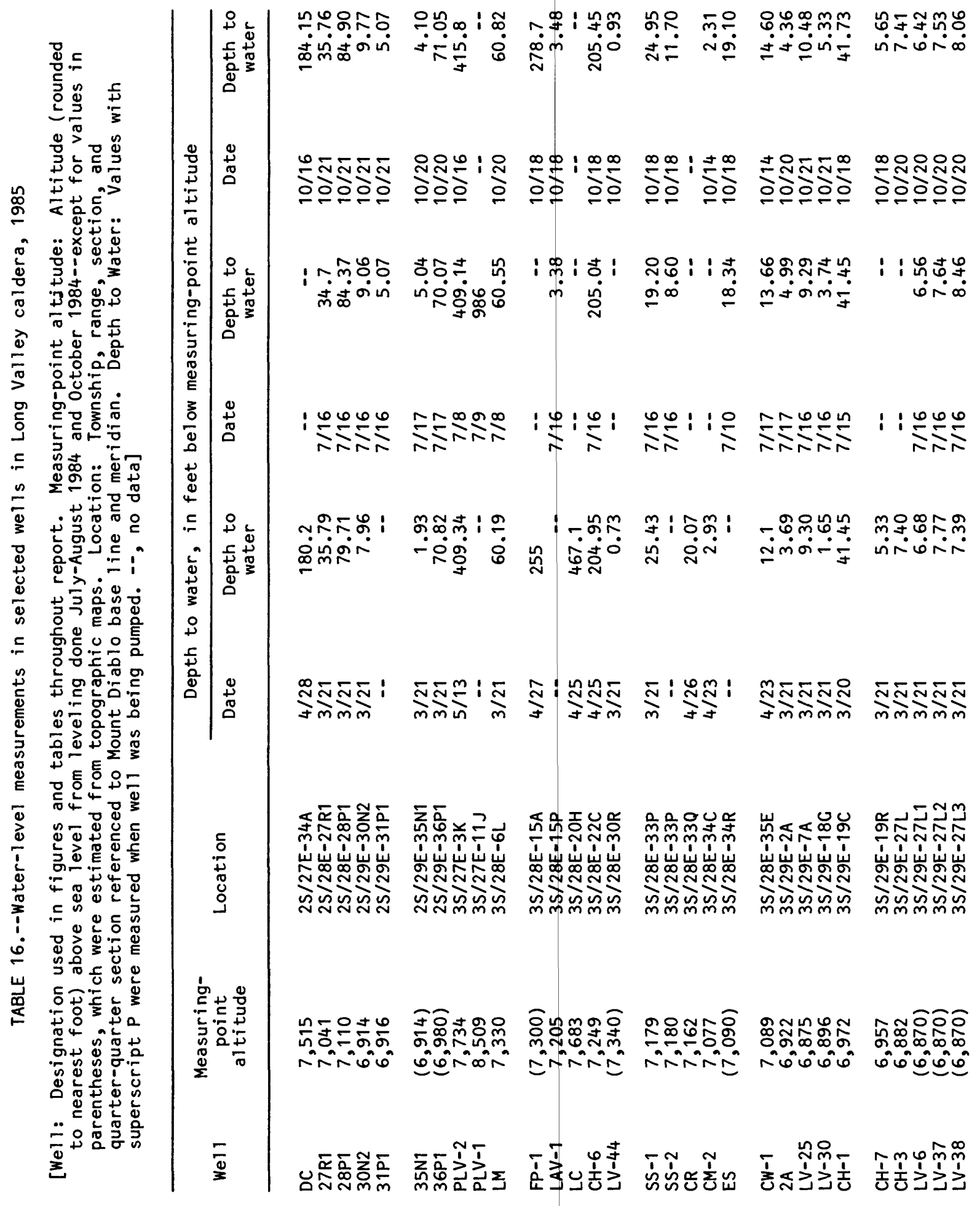




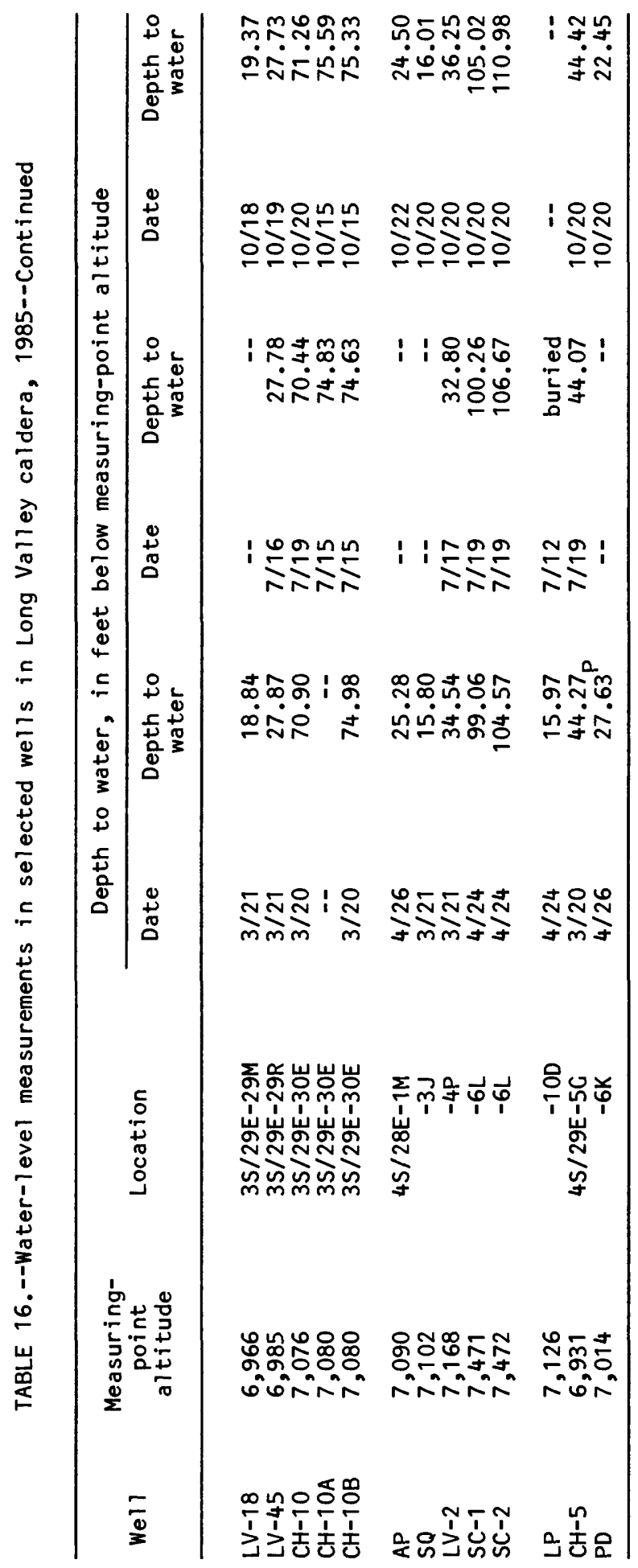

